\title{
ANDRÉ GRESPAN
}

Clamidiose em calopsitas (Nymphicus hollandicus): perfil do proprietário e ensaio terapêutico 


\section{ANDRÉ GRESPAN}

Clamidiose em calopsitas (Nymphicus hollandicus): perfil do proprietário e ensaio terapêutico

Dissertação apresentada ao Programa de Pós-Graduação em Epidemiologia Experimental Aplicada às Zoonoses da Faculdade de Medicina Veterinária e Zootecnia da Universidade de São Paulo para obtenção do título de Mestre em Ciências.

\section{Departamento:}

Medicina Veterinária Preventiva e Saúde Animal

\section{Área de concentração:}

Epidemiologia Experimental Aplicada às Zoonoses

Orientador:

Profa. Dr ${ }^{\text {a }}$. Sônia Regina Pinheiro

São Paulo

2009 
Autorizo a reprodução parcial ou total desta obra, para fins acadêmicos, desde que citada a fonte.

DADOS INTERNACIONAIS DE CATALOGAÇÃO-NA-PUBLICAÇÃO

(Biblioteca Virginie Buff D’Ápice da Faculdade de Medicina Veterinária e Zootecnia da Universidade de São Paulo)

T.2227

FMVZ

\section{Grespan, André}

Clamidiose em calopsitas (Nymphicus hollandicus): perfil proprietário e ensaio terapêutico / André Grespan. -- 2009.

$111 \mathrm{f}$ : : il.

Dissertação (Mestrado) - Universidade de São Paulo. Faculdade de Medicina Veterinária e Zootecnia. Departamento de Medicina Preventiva e Saúde Animal, São Paulo, 2010.

Programa de Pós-Graduação: Epidemiologia Experimental Aplicada às Zoonoses.

Área de concentração: Epidemiologia Experimental Aplicada às Zoonoses.

Orientador: Profa. Dra. Sônia Regina Pinheiro.

1. Clamidiose aviária. 2. Calopsitas. 3. Tratamento. 4. Nymphicus hollandicus. I. Título. 


\section{ERRATA}

Página

Parágrafo Linha

Onde se lê

perfil proprietário e

Leia-se

Ficha catalográfica 


\section{FACULDADE DE MEDICINA VETERINÁRIA E ZOOTECNIA} Comissio Bioética

\section{CERTIFICADO}

Certificamos que o Projeto intitulado "Estudo do impacto da antibioticoterapia no tratamento de clamidiose em aves de companhia atendidas em clinica veterinária particular do Municipio de Sào Pauto", protocolado sob o $\mathrm{n}^{\prime} 1392 / 2008$, utilizando 30 (trinta) psitacideos, sob a responsabilidade da Profa. Dra. Sônia Regina Pinheiro, está de acordo com os princípios éticos de experimentaçào animal da Comissāo de Bioètica da Faculdade de Medicina Veterinária e Zootecnia da Universidade de Sāo Paulo e foi aprovado na reuniāo do dia 18 de junho de 2008.

We certify that the Research "Study of the antibiotic therapy's impact as treatment for chlamydiosis in pet birds in a Sao Paulo city's private clinic", protocol number 1392/2008, utilizing 30 (thirty) pet birds, under the responsibility Profa. Dra. Sonia Regina Pinheiro, agree with Ethical Principles in Animal Research adopted by Bioethic Commission of the School of Veterinary Medicine and Animal Science of University of Sāo Paulo and was approved in the meeting of day $06 / 18 / 08$.

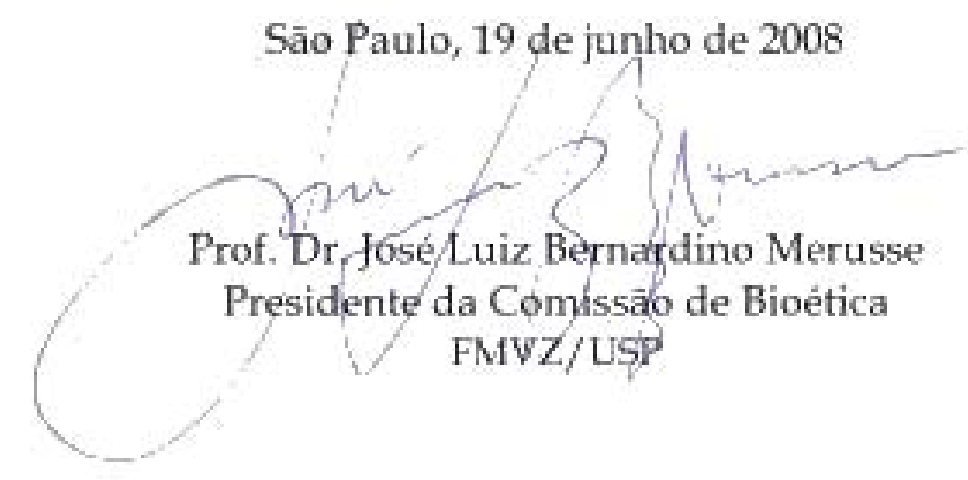


Nome: GRESPAN, André

Título: Clamidiose em calopsitas (Nymphicus hollandicus): perfil do proprietário e ensaio terapêutico.

Dissertação apresentada ao Programa de Pós-Graduação em Epidemiologia Experimental Aplicada às Zoonoses da Faculdade de Medicina Veterinária e Zootecnia da Universidade de São Paulo para obtenção do título de Mestre em Ciências.

Data:

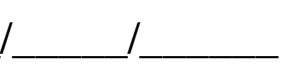

Banca Examinadora

Prof. (a) Dr. (a) Instituição:

Assinatura Julgamento:

Prof. (a) Dr. (a) Instituição:

Assinatura Julgamento:

Prof. (a) Dr. (a) Instituição:

Assinatura Julgamento: 


\section{DEDICATÓRIA}

À meus pais, Milton Grespan e Marilene Pinheiro Grespan, por suas histórias de sucesso na educação do filho, diante de todas as adversidades.

À minha adorada futura esposa, Fabiana Santos Ferreira, que me ensinou as prioridades na vida.

Aos meus animais de estimação, Kirov, Luna. Totó, Gatoleco, Lala, McFly, Rick, Xuxa, Chuzinho, Chuzinha, Peter, Borg, Potira, Cabecao, Gorda, Catarina, Cosme, Tico-Mico, Chanel, Provolone, Cotó, Jayson e tantos outros, motivo de entusiasmo e paixão pela profissão.

Aos pacientes, objetivo maior de toda atividade científica. 


\section{AGRADECIMENTOS}

À Profa. Dra. Sônia Regina Pinheiro, pela determinação, empenho e valorosa orientação neste trabalho.

Ao Prof. Dr. Sílvio Arruda Vasconcellos pela atenção e sugestões importantes para finalização de trabalhos de qualidade.

Ao Doutorando Miguel Bernardino dos Santos pela amizade, sugestões e apoio.

À Profa. Dra. Vania Maria de Carvalho, pelo incentivo ao trabalho científico no inicio da minha vida acadêmica, com quem tudo começou e a seu esposo Prof. Dr. José Luis Catão Dias (FMVZ-USP) pela paciência, carinho e apoio.

À Profa. Dra. Tania Freitas Raso (FMVZ-USP), pelo apoio ao projeto desde sua implantação e pelos conselhos sempre muito bem colocados e oportunos.

Profa. Dra. Eliana Heiko Matushima (FMVZ-USP), pelo apoio e ajuda no inicio de minha vida profissional.

Aos meus amigos da Wildvet sem os quais este trabalho não seria possível:

Marcos Pato, Flavia Agostine, Arabeli Tomase, Justiniano Proença, Priscila Bernardes e também para José Selmi e as dezenas de estagiários e amigos que passaram pela clinica desde sua fundação.

Agradecimentos especiais:

Ao Prof. Dr. Ricardo Augusto Dias (FMVZ-USP) pela colaboração na revisão final da estatística.

À Mestranda Patrícia Coutinho de Souza pela a ajuda fundamental na avaliação histopatológica e pela amizade sincera. 
"- Por favor, cativa-me! — disse a raposa.

- Bem quisera - disse o príncipe - mas eu não tenho tempo. Tenho amigos a descobrir e mundos a conhecer.

- A gente só conhece bem as coisas que cativou - disse a raposa. - Os homens não têm tempo de conhecer coisa alguma. Compram tudo prontinho nas lojas. Mas como não existem lojas de amigos, os homens não têm mais amigos.

Se tu queres uma amiga, cativa-me!

- Os homens esqueceram a verdade - disse a raposa. - Mas tu não a deves esquecer. Tu te tornas eternamente responsável por aquilo que cativas." Antoine de Saint-Exupéry "O Pequeno Príncipe " 


\section{RESUMO}

GRESPAN, A. Clamidiose em calopsitas (Nymphicus hollandicus): perfil do proprietário e ensaio terapêutico. [Chlamydiosis in cockatils (Nymphicus hollandicus): Profile of the owner and therapeutic trial]. 2009. 111f. Dissertação (Mestrado em Ciências) - Faculdade de Medicina Veterinária e Zootecnia, Universidade de São Paulo, 2010.

A prática popular de manutenção de aves como animais de estimação é um importante fator de risco à saúde pública. Não obstante o benefício gerado pelo convívio com o animal, as aves também podem albergar agentes de doenças transmissíveis para seres humanos. A Chlamydophila psittaci, ocupa uma posição de destaque dentre as zoonoses de origem aviária. O presente estudo, que teve como objetivo, em uma primeira etapa, determinar o nível de conhecimento dos proprietários de aves sobre manejo e zoonoses. No segundo momento, calopsitas (Nymphicus hollandicus), naturalmente infectadas com C. psittaci foram submetidas a um protocolo de tratamento com antibiótico durante quarenta e cinco dias consecutivos. Foram efetuadas biopsias hepáticas e swabs de cloaca, submetidos à técnica de PCR e cultura bacteriológica, para avaliar o impacto do tratamento no organismo do animal, microbióta bacteriana e o estado do portador. Concluiu-se que os proprietários precisam de uma orientação mais contundente e direcionada à prevenção e manejo de suas aves; o protocolo de tratamento utilizando a doxiciclina foi eficaz, eliminando a positividade das aves; as avaliações observadas nas biópsias hepáticas não mostraram alterações significativas que pudessem contribuir com o diagnóstico da clamidiose.

Palavras-chave: Clamidiose aviária. Calopsitas. Tratamento. Nymphicus hollandicus. 


\section{ABSTRACTS}

GRESPAN, A. Chlamydiosis in cockatils (Nymphicus hollandicus): Profile of the owner and therapeutic trial. [Clamidiose em calopsitas (Nymphicus hollandicus): perfil do proprietário e ensaio terapêutico]. 2009. 111f. Dissertação (Mestrado em Ciências) - Faculdade de Medicina Veterinária e Zootecnia, Universidade de São Paulo, 2010.

The maintenance of pet birds in home cages is a risk to public heath, this animals can house important zoonotic agents like Chlamydophila psittaci, that causes avian clamydiosis. The first aim of this study was to measure the clamydiosis knowledge level of bird owners that had their animals treated in a private veterinary clinic in São Paulo trough a questionnaire with semi-opened questions about behaviour, handling and cleaning of their pets. The second aim of this report was to evaluate the doxiciclin treatment eficacy in naturally infected cockatiels (Nymphicus hollandicus) with oral aplications of $25-35 \mathrm{mg}$ doxicicin/kg/day during 45 consecutive days. Every bird has had two liver biopsies done: the first before the treatment and the second one after that. During the treatment severam cloacal swabs were performed to evaluate the treatment impact in the digestive microbiota trough PCR and bacterial culture. The present study concludes that the bird owners need to be better informed about handling and disease prevention. Besides, the doxiciclin treatment was effective when evaluated trough the histopathologic evaluation (liver biopsies), making the positive samples turn to negative after 45 days. The liver collection was concedered a safe procedure, not causing mortality or complications after it and the samples were representative to the determined diagnosis. The liver evaluation could not show any significant variation that would help in the clamidiosis diagnose.

Keywords: Bird clamydiosis. Cockatiel. Treatment. Nymphicus hollandicus. 


\section{LISTA DE APÊNDICES}

Apêndice A - Questionário aplicado em 100 proprietários de aves atendidos na clínica veterinária Wildvet e avaliados durante a primeira

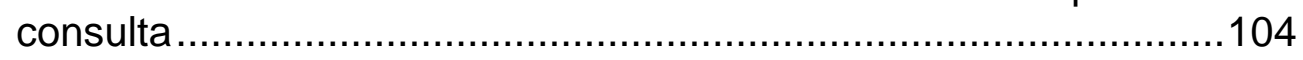

Apêndice B - Ficha de acompanhamento das aves durante o período de

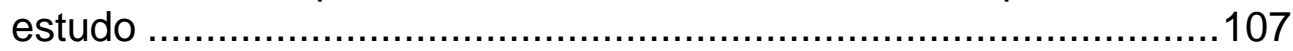




\section{LISTA DE ANEXOS}

Anexo A - Minuta - NOTA TÉCNICA SOBRE PROVÁVEL SURTO DE PSITACOSE - Centro Estadual de Vigilância em Saúde da SES-

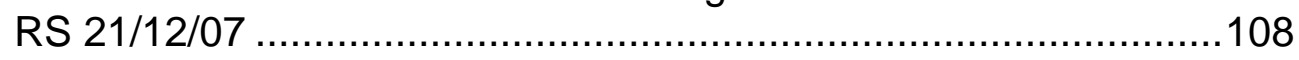




\section{LISTA DE FIGURAS}

Figura 1 - Esquema de aporte sanguíneo e regiões hepáticas.

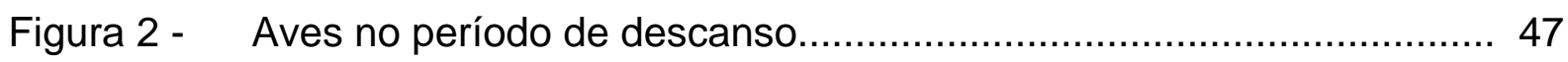

Figura 3 - Procedimento de identificação das calopsitas.................................... 48

Figura 4 - Gaiolas e ambiente de trabalho. .................................................. 49

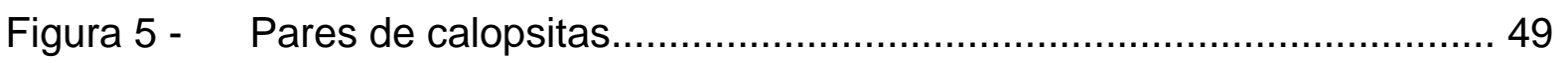

Figura 6 - Visão geral das gaiolas utilizadas ……….................................... 50

Figura 7 - Fluxograma de atividades experimentais. ….................................. 51

Figura 8 - Swab de cloaca para colheita de material (vista ventro-dorsal). ....... 51

Figura 9 - Swab de cloaca para colheita de material (vista látero-lateral). ......... 52

Figura 10 - Material cirúrgico empregado na biópsia hepática. .............................. 53

Figura 11 - Visualização da linha alba. ............................................................. 54

Figura 12 - Contenção física e colheita de material. ......................................... 55

Figura 13 - Administração da medicação. …………........................................... 57

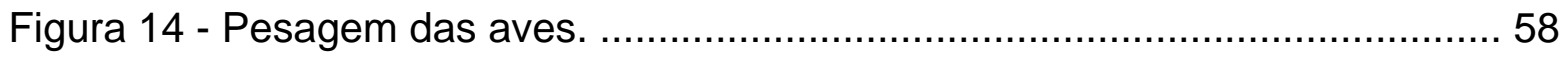




\section{LISTA DE TABELAS}

Tabela 1 - Classificação da Chlamydophila psittaci segundo designação de sorotipo, estirpe representativa e hospedeiro preferencial (ANDERSEN e VANROMPAY, 2000)..................................... 20

Tabela 2 - Hospedeiros preferenciais e intensidade de associação de sorotipos de C. psittaci.

Tabela 3 - Valores atribuídos às calopsitas naturalmente infectadas por $C$. psittaci e tratadas com doxiciclina segundo o número de identificação, momento de avaliação corpórea e dos resultados dos cultivos microbiológicos e PCR efetuados no início e final do tratamento. São Paulo, 2009.

Tabela 4 - Valores atribuídos às calopsitas naturalmente infectadas por $C$. psittaci e não tratadas com doxiciclina segundo o número de identificação, momento de avaliação corpórea e dos resultados dos cultivos microbiológicos e PCR efetuados no início e final do tratamento. São Paulo, 2009. 70

Tabela 5 - $\quad$ Alterações histopatológicas circulatórias (congestão) encontradas nas biópsias hepáticas das calopsitas naturalmente infectadas com C. psittaci segundo a identificação da ave, grupo experimental e o momento da avaliação. São Paulo, 2009. 75

Tabela 6 - $\quad$ Alterações histopatológicas degenerativas encontradas nas biópsias hepáticas das calopsitas naturalmente infectadas com C. psittaci segundo a identificação da ave, grupo experimental e o momento da avaliação. São Paulo, 2009. 76

Tabela 7 - Alterações histopatológicas inflamatórias encontradas nas biópsias hepáticas das calopsitas naturalmente infectadas com C. psittaci segundo a identificação da ave, grupo experimental e o momento da avaliação. São Paulo, 2009. 


\section{LISTA DE QUADROS}

Quadro 1 - Respostas referentes à saúde da ave, obtidas de 100 proprietários de aves atendidos na clínica veterinária Wildvet e avaliados durante a primeira consulta.

Quadro 2 - Respostas referentes o manejo e higiene da ave, obtidas de 100 proprietários de aves atendidos na clínica veterinária Wildvet e avaliados durante a primeira consulta. 62

Quadro 3 - Respostas referentes à correlação e conhecimento de zoonoses aviarias, obtidas de 100 proprietários de aves atendidos na clínica veterinária Wildvet e avaliados durante a primeira consulta. 


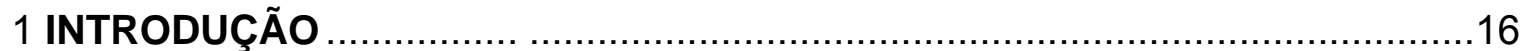

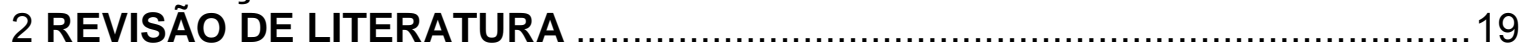

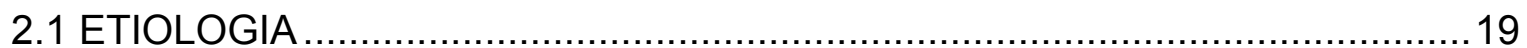

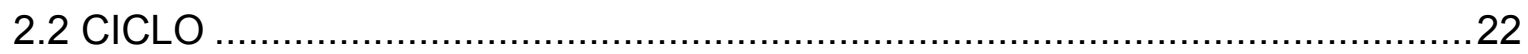

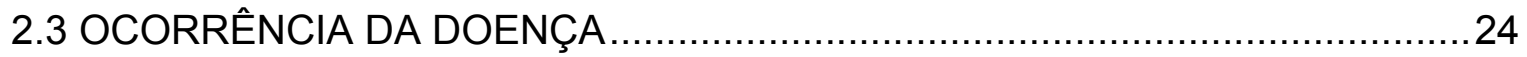

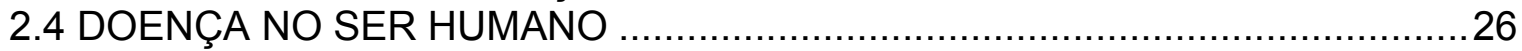

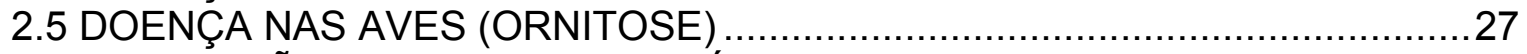

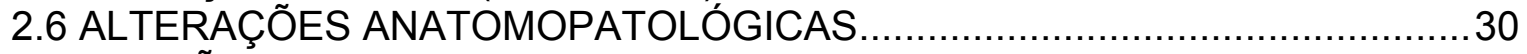

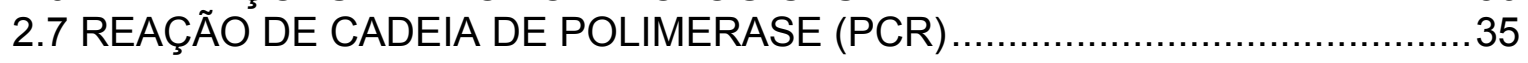

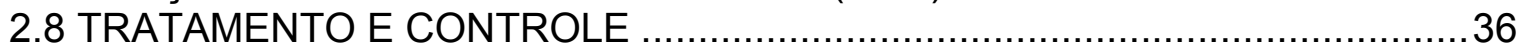

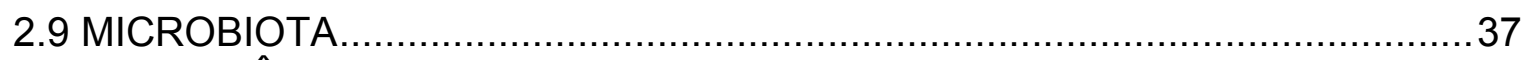

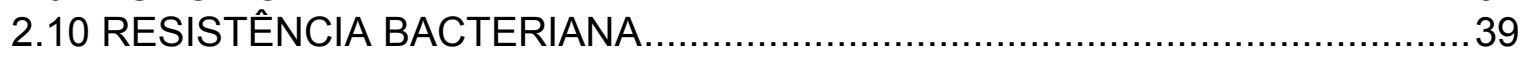

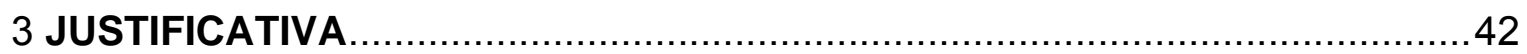

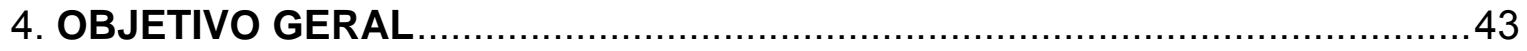

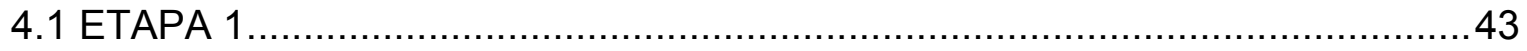

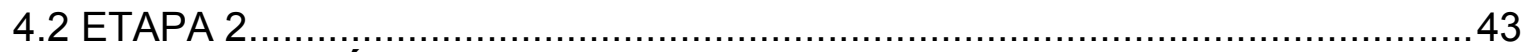

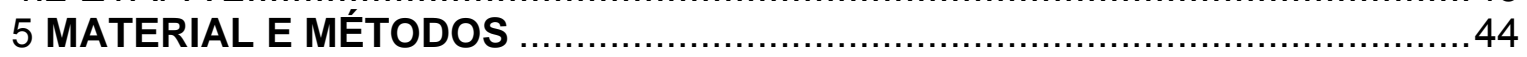

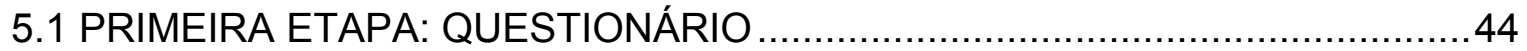

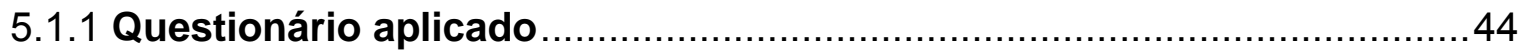

5.1.2 Avaliação do questionário aplicado ................................................ 45

5.2 SEGUNDA ETAPA: AVALIAÇÃO DE UM PROTOCOLO DE TRATAMENTO .. 45

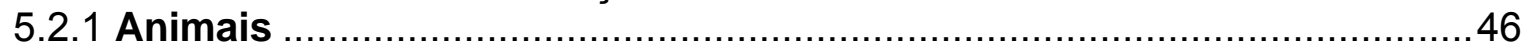

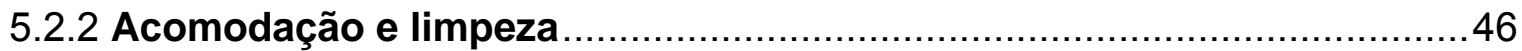

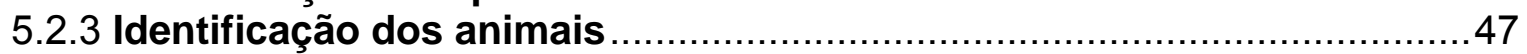

5.2.4 Formação dos grupos experimentais ................................................. 48

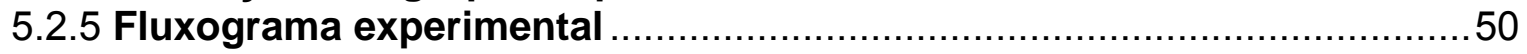

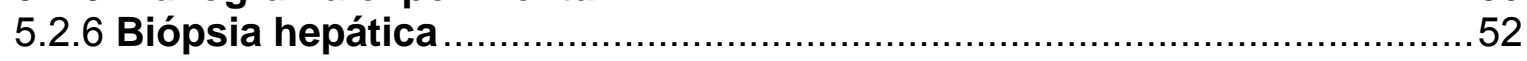

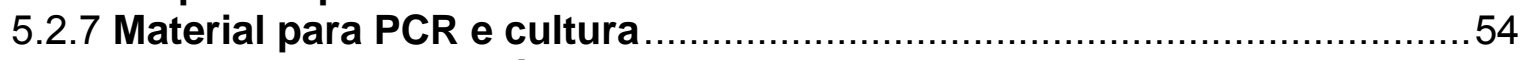

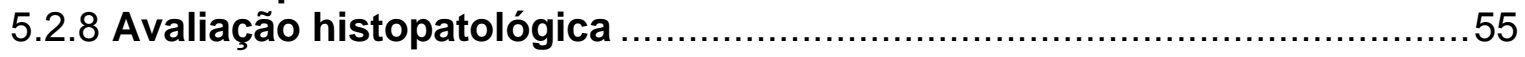

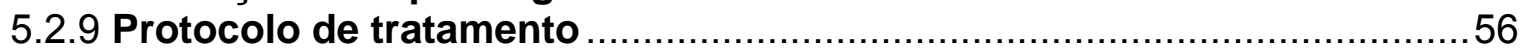

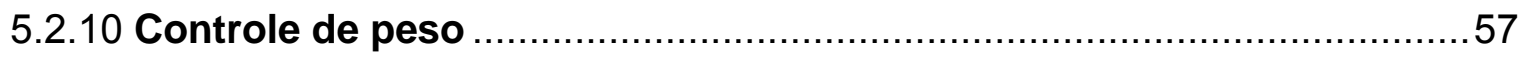

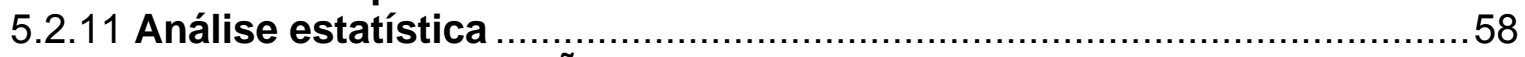

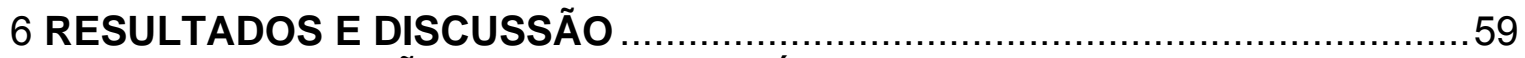

6.1 CARACTERIZAÇÃO DOS PROPRIETÁRIOS PARTICIPANTES ....................59

6.2. AVALIAÇÃO DO PROTOCOLO DE TRATAMENTO ADOTADO .....................67

6.3 RESULTADDOS DOS EXAMES HISTOPATOLÓGICOS ................................. 74

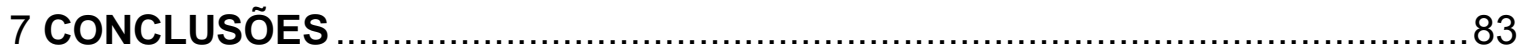

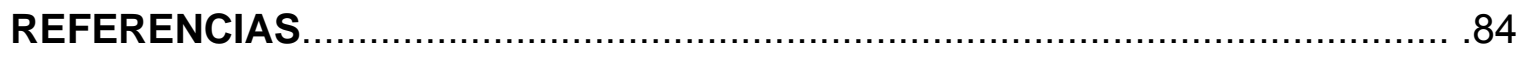




\section{INTRODUÇÃO}

A manutenção de um animal de companhia tem sido associada a benefícios físicos e emocionais para os seus proprietários, pois os "pets" podem ter uma influência positiva na qualidade de vida das pessoas (SPENCER, 1992). As aves, principalmente as calopsitas ( $N$. hollandicus), se destacam no comércio "pet" em decorrência do baixo custo de aquisição e manutenção, bem como por sua beleza, canto e docilidade.

A prática popular da manutenção de aves, como animais de estimação, é um importante fator para a saúde pública. Não obstante o benefício gerado pelo convívio com o animal, as aves também podem albergar agentes de doenças transmissíveis para os seres humanos.

O potencial zoonótico das aves de companhia não se limita ao contato direto com elas, mas pode estar associado a atividades executadas no ambiente que elas ocupam, tais como jardinagem e podas de árvores e gramados tanto no ambiente urbano quanto no rural (TELFER et al., 2005; FENGA et al, . 2007).

Dentre as zoonoses de origem aviária, a clamidiose, doença provocada pela Chlamydophila psittaci, ocupa uma posição de destaque. Este agente é uma bactéria eliminada pelas fezes e secreções de aves doentes ou portadoras que pode, assim, vir a infectar outros animais e o homem.

A Chlamydophila psittaci é cosmopolita e endêmica no Brasil; pode causar uma infecção subclínica inaparente, aguda, subaguda ou crônica, com elevada mortalidade de aves selvagens e domésticas, caracterizada por infecção intestinal, ocular, respiratória ou sistêmica. A gravidade da doença varia de acordo com o sorotipo e a suscetibilidade da espécie envolvida.

A infecção pela C. psittaci é uma das principais zoonoses transmitidas por aves silvestres, contudo a incidência em humanos é baixa, o que contrasta com o número de aves portadoras.

No homem, o período de incubação da infecção por C. psittaci situa-se entre 5 e 14 dias, e as manifestações clínicas vão de infecção inaparente a doença 
sistêmica grave. Os pacientes apresentam dor de cabeça, calafrios, mal-estar e mialgia. Eventualmente há o comprometimento pulmonar.

Em indivíduos adequadamente tratados, a doença raramente é fatal, daí a necessidade do seu conhecimento, da consciência do risco com as aves e a necessidade do estabelecimento do diagnóstico precoce.

As medidas de prevenção e controle da clamidiose aviária assumem capital importância, pois esta interação apresenta dificuldades de diagnóstico e tratamento; podem ocorrer portadores assintomáticos, com potencial zoonótico, e as aves submetidas ao tratamento podem continuar a eliminar o agente por longo período de tempo.

Diante da gravidade da doença, do risco à saúde pública, do caráter de doença ocupacional e do número restrito de investigações direcionadas ao tema, foi delineado o presente trabalho, desenvolvido em uma clínica veterinária particular no Município de São Paulo, especializada no atendimento de animais selvagens. O estudo consistiu na aplicação de um questionário que avaliou o nível de conhecimento dos proprietários de aves sobre a clamidiose relativamente à etiologia, epidemiologia, sinais clínicos, tratamentos, prevenção e controle, e foi investigada a eficácia de um protocolo de tratamento com antimicrobianos.

As condições de bioconfinamento de aves suscetíveis a C. psittaci devem ser revistas, uma vez que os seres humanos são frequentemente infectados por inalação do organismo oriundo de urina, secreções respiratórias ou fezes secas de aves infectadas que podem ser dispersos no ar como gotículas ou partículas de poeira. Outras fontes de exposição incluem contato direto, boca-bico, boca-pena, bicada de uma ave infectada e dissecção de aves mortas ou evisceração em matadouros.

A importância para a saúde pública é dada em virtude da popularidade de aves, como animais de estimação, presentes em creches, centros de jardim e casas de repouso. Além disso, os pombos selvagens em ambientes urbanos são geralmente infectados, apresentando um risco à população em geral (HAAGWACKERNAGEL, 2005; LAROUCAU et al., 2005; MITEVSKI et al., 2005). O risco zoonótico não se limita ao contato direto com aves, mas também está associado a 
um ambiente rural e atividades ao ar livre, como jardinagem e podas de árvores e gramados (TELFER et al., 2005; FENGA et al., 2007), bem como à transmissão de pessoa para pessoa, que se acredita ser raro (HUGHES et al., 1997; ITO et al., 2002).

Na Bélgica, sete, dois e três casos de psitacose foram relatados em 2005, 2006 e 2007, respectivamente. Na Austrália, Alemanha, Suécia e Holanda, 62, 10, 9 e 27 casos foram notificados em 2007 (HARKINEZHAD et al., 2009). Estes dados podem estar subestimados em relação à clamidiose humana de origem aviária pela dificuldade do diagnóstico preciso, além do fato de que, muitas vezes, os casos não são corretamente relatados porque os pacientes apresentam melhora clínica quando cobertos por agentes antimicrobianos empregados empiricamente para uma pneumonia adquirida na comunidade.

Um inquérito soroepidemiológico realizado por Raso et al.(2009) confirma a ocorrência de infecção e contato prévio de trabalhadores de zoológicos brasileiros com a C. psittaci, bem como o potencial zoonótico da clamidiose nesta população, concluindo que outros estudos são necessários para avaliar os fatores de risco e a necessidade de adotar medidas preventivas de controle da clamidiose aviária para proteger a saúde dos trabalhadores de zoológicos no país.

No presente estudo foi feita uma revisão sobre a Chlamydophila psittaci nos itens relativos à sua etiologia, epidemiologia, sinais clínicos, alterações anatomopatológicas, diagnóstico, tratamento, prevenção e controle. Foi identificada a necessidade de orientar proprietários e criadores de aves, médicos veterinários e outros profissionais sobre os riscos e cuidados em relação a esta zoonose. 


\section{REVISÃO DE LITERATURA}

As primeiras descrições de seres humanos infectados com clamídia são encontradas em manuscritos chineses e egípcios, que relatam a sensação de "areia nos olhos" (tracoma).

Os métodos de diagnóstico molecular, baseados na amplificação de ácidos nucleicos, conduziram à descoberta de clamídias em tecidos e células nunca antes relatados (articulações, placas ateroscleróticas, cérebro, amebas) e associados com doenças de etiologias desconhecidas na época: artrite, doença de Alzheimer e doença arterial coronária (EVERETT et al., 1999). Mais de 40 linhagens de clamídias já foram descritas na American Type Culture Collection, incluindo estirpes de todas as espécies e famílias. As clamídias ambientais também foram descobertas em uma ampla gama de filos animais.

\subsection{ETIOLOGIA}

Os micro-organismos da família Chlamydiaceae são bactérias obrigatoriamente intracelulares presentes em aves, répteis e mamíferos. As diferentes espécies desta família podem infectar vários animais, com variável tropismo tecidual, causando doença de múltiplos sinais clínicos, com características agudas ou crônicas, incluindo doenças respiratórias, cardiovasculares, sexuais e oftalmológicas. Antes da reclassificação em 1999, o gênero Chlamydia era dividido em quatro espécies: C. trachomatis, C. pecorum, C. pneumoniae e C. psittaci. Em 1999, Everett, Bush e Andersen, propuseram uma nova classificação, após análise dos genes $16 \mathrm{~S}$ e $23 \mathrm{~S}$ rRNA, considerando informações fenotípicas, morfológicas e genéticas. A família Chlamydiaceae foi então dividida em dois gêneros: Chlamydia e Chlamydophila, compostos por nove espécies. Na espécie C. psittaci estão incluídos seis sorovares de origem aviária, designados pelas letras A a F (Tabela 
1), e dois sorovares isolados de mamíferos (WC e M56) ( ANDERSEN, 1991b; VANROMPAY et al., 1993; VANROMPAY et al., 1997).

Os anticorpos monoclonais utilizados para distinguir os sorotipos aviários (ANDERSEN, 1991a, 1997) analisam o gene de codificação das proteínas da membrana externa (OMPA). Esta técnica é, na atualidade, a mais utilizada para caracterizar os genótipos de estirpes de clamídias que infectam aves. Os genótipos OMPA (A-F, E / B, M56 e CC) são largamente congruentes com os sorotipos e podem ser distinguidos pelo sequenciamento (EVERETT et al., 1999); PCR realtime (GEENS et al., 2005) ou microarrays (SACHSE et al., 2008).

Tabela 1 - Classificação da Chlamydophila psittaci segundo designação de sorotipo, estirpe representativa e hospedeiro preferencial (ANDERSEN; VANROMPAY, 2000)

\begin{tabular}{ccc}
\hline Sorotipo & Estirpe representativa & Hospedeiro associado \\
\hline A & VS1 & Psitacídeos \\
B & CP3 & Pombos \\
C & GR9 & Patos e gansos \\
D & NJ1 & Perus \\
E & MN & Pombos e perus \\
F & VS225 & Psitacídeos \\
WC & WC & Ruminantes \\
M56 & M56 & Lebre americana e murídeos \\
\hline
\end{tabular}

Fonte: European Commission - EC (2002)

Os genótipos conhecidos de C. psittaci apresentam hospedeiros preferenciais, entretanto todos os genótipos devem ser considerados como facilmente transmissíveis para os seres humanos e potencialmente causadores de doenças graves que podem evoluir para a morte.

Os genótipos A e B estão normalmente associados, respectivamente, a psitaciformes e pombos. O genótipo $\mathrm{C}$ tem sido isolado de patos e gansos, o genótipo $D$ foi encontrado em perus e o genótipo $F$ foi isolado em psitacídeos e perus. A gama de hospedeiros do genótipo $\mathrm{E}$ é a mais diversificada e corresponde a $20 \%$ das estirpes isoladas de pombos. Foi isolada em muitos casos fatais em aves de corte, responsáveis por manifestações respiratórias em patos e perus, e 
ocasionalmente em seres humanos. Os sorotipos WC e M56 foram isolados em epizootias ocorridas, respectivamente, em bovinos e lebres (EUROPEAN COMMISSION - EC, 2002).

A clamidiose por Chlamydophila psittaci é também conhecida como psitacose ou febre dos papagaios, quando restrita aos psitacídeos; e ornitose, quando acomete diversas espécies de aves domésticas e selvagens (MEYER, 1965; RASO, 2007). Contudo, como as estirpes de C. psittaci isoladas de psitacídeos e não psitacídeos são responsáveis pelo mesmo tipo de doença em aves de diferentes espécies (PAGE, 1966) (Tabela 2), o nome universal melhor aplicado é o termo clamidiose, que pode ser empregado para descrever infecções por clamídia em humanos, aves e mamíferos.

Tabela 2 - Hospedeiros preferenciais e intensidade de associação de sorotipos de C. psittaci.

\begin{tabular}{|c|c|c|c|c|c|c|}
\hline Espécie & $\mathbf{A}$ & B & $\mathrm{C}$ & D & $\mathbf{E}$ & $\mathbf{F}$ \\
\hline Psitacídeos & +++ & & & & & + \\
\hline Pombos & & +++ & & & +++ & \\
\hline Anatideos & & & +++ & & & \\
\hline Perus & + & + & & +++ & + & \\
\hline Gaivotas e garças & & & & +++ & & \\
\hline Ratitas & & & & & +++ & \\
\hline Pássaros selvagens & & +++ & & & +++ & \\
\hline
\end{tabular}

Fonte: The Merck Veterinary Manual (2006)

As taxas de morbidade e mortalidade da clamidiose aviária variam com a espécie hospedeira e a patogenicidade dos sorotipos (CFSPH, 2005). A taxa de morbidade é elevada. Em psitacídeos, portadores inaparentes, esta taxa varia de $10 \%$ a $40 \%$, atingindo $100 \%$ em alguns locais; algo semelhante foi verificado em criadouros brasileiros (RASO, 2007).

Em perus adultos, o sorotipo D de C. psittaci pode causar $50 \%-80 \%$ de morbidade, e em perus jovens, este índice poder ser superior a $80 \%$; outros sorotipos resultam em morbidade de $5 \%-20 \%$. Em patos, a morbidade pode atingir 
80\% (ORGANIZAÇÃO INTERNACIONAL DE EPIZOTIAS, 2004; CENTER FOR FOOD SECURITY AND PUBLIC HEALTH, 2005).

A clamidiose aviária apresenta uma taxa de mortalidade extremamente variável. Sorotipos que causam doença subclínica ou inaparente em determinadas espécies aviárias podem causar doença letal em outras. Em criatórios onde a doença é endêmica, a mortalidade é maior em aves jovens, com perdas máximas de $10 \%$. Contudo, em criatórios sem doença, a taxa de mortalidade pode atingir a 90\% (RASO, 2007). Infecções concorrentes ou estresse aumentam a severidade da doença (CENTER FOR FOOD SECURITY AND PUBLIC HEALTH, 2005). As infecções bacterianas secundárias, principalmente por E. coli e Salmonela sp, podem deprimir o sistema imune da ave, e assim elevar a taxa de mortalidade (RASO, 2007).

\subsection{CICLO}

A C. psittaci apresenta um ciclo de desenvolvimento bifásico, com duas formas morfológicas e funcionalmente distintas: o corpo elementar e o corpo reticular. $\mathrm{O}$

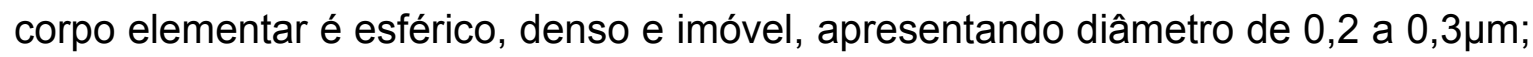
é a forma extracelular infecciosa e metabolicamente inativa. O corpo reticular, que

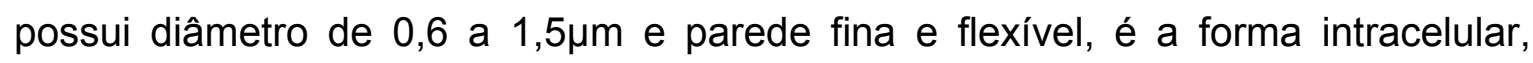
metabolicamente ativa. Ambos possuem membrana externa semelhante à de algumas bactérias Gram-negativas, composta de fosfolipídeos, lipídeos, lipopolissacarídeos e proteínas (RASO, 2007).

O ciclo de desenvolvimento da C. psittaci tem início com a união e penetração do corpo elementar na célula do hospedeiro por endocitose. Em seguida, diferenciase em corpo reticular pela redução das ligações cruzadas entre as pontes dissulfeto das proteínas da membrana externa de sua parede celular. O corpo reticular parasita a mitocôndria da célula hospedeira, extraindo a energia necessária para o seu crescimento e sua multiplicação. Ocorre então a síntese de DNA, RNA e 
proteínas, e a multiplicação do corpo reticular por divisão binária, formando microcolônias contendo de 100 a 500 micro-organismos por célula, os chamados corpúsculos de inclusão ou corpos de Levintal-Collie-Lilie (LCL). Após maturação, os corpos reticulares transformam-se novamente em corpos elementares, que são liberados pela lise da célula hospedeira. Esta lise ocorre em decorrência das enzimas produzidas pelo parasita intracelular. Todo o ciclo de desenvolvimento do agente tem duração aproximada de 48 horas (GUERLACH, 1994).

As células infectadas podem transmitir a C. psittaci para as células filhas durante seu processo de divisão, perpetuando assim a infecção, sem liberação sistêmica de corpos elementares imunogênicos. A carência de elementos nutritivos na célula hospedeira faz com que as clamídias entrem temporariamente em estado letárgico, podendo permanecer inativas por longos períodos (RASO, 2007).

Beer (1988a) constatou que as aves infectadas eliminam a C. psittaci entre três e 174 dias do contágio artificial. O período de incubação da doença nas aves varia geralmente de alguns dias a várias semanas, podendo, no entanto, estenderse por anos, o que torna difícil a avaliação do momento da infecção em casos naturais. A infecção inicial ocorre quando os corpos elementares presentes em restos de penas e excreções secas se dispersam no ambiente pela circulação do ar e infectam células epiteliais de indivíduos suscetíveis.

Nas infecções primárias, a C. psittaci é mais facilmente detectada em amostras provenientes da traqueia e/ou orofaringe, visto que o sistema respiratório superior é o local de instalação primária do agente (BEER, 1988b; RASO, 2007). As aves clinicamente doentes apresentam maior índice de eliminação do agente que as aves portadoras inaparentes. As aves mais jovens são mais suscetíveis à infecção, podendo eliminar o agente com maior frequência e quantidade (FRIEND; FRANSON e CHRISTIAN, 1999; RUPLEY, 1999; CENTER FOR FOOD SECURITY AND PUBLIC HEALTH, 2005).

A C. psittaci é sensível ao calor e aos agentes que destroem os componentes lipídicos da parede celular, tais como formalina, peróxido de hidrogênio a 3\%, etanol a 70\% e compostos de amônia quaternária (KHAN, 2006; RASO, 2007). Quando 
protegidos por matéria orgânica presente em fezes ou secreções, os corpos elementares podem sobreviver por meses à dessecação ou ação direta do sol.

A transmissão da C. psittaci ocorre predominantemente por inalação de aerossóis contaminados por urina, fezes, secreções respiratórias e oculares, de um animal doente ou portador assintomático. O manuseio da plumagem e tecidos das aves infectadas e o contato direto boca-bico apresentam um risco de infecção elevado. Além disso, atividades como jardinagem e podas de árvores e grama têm sido associadas com clamidiose humana de origem aviária, sugerindo que essas atividades apresentam risco de exposição ao agente infeccioso (WILLIAMS et al., 1998; TELFER et al., 2005). A transmissão da clamidiose aviária de pessoa para pessoa é possível, porém rara (HUGHES et al., 1997; ITO et al., 2002).

As aves portadoras da C. psittaci podem transmitir o agente para outras aves ou seres humanos pelo contato com secreções e fluidos, onde a bactéria pode persistir viável por meses. A transmissão da doença ocorre principalmente pela inalação de aerossóis fecais ou de penas e também por poeira contaminada. A infecção oral é uma rota alternativa e importante em aves "pet" (SHEWEN, 1980).

A transmissão via ovo foi demonstrada em galinhas, patos, gaivotas e psitacídeos. No entanto, a maioria dos ovos infectados costuma não eclodir. No ninho, os pais podem infectar suas crias; o período de incubação pode variar de alguns dias a muitos anos, o que dificulta o diagnóstico. As aves jovens são mais suscetíveis à infecção do que animais adultos, e algumas espécies parecem ser mais sensíveis que outras. Muitas vezes, as aves portadoras podem ser identificadas pela transmissão da doença para outras aves ou pela morte súbita de jovens no ninho com pais clinicamente saudáveis (SHEWEN, 1980).

\subsection{OCORRÊNCIA DA DOENÇA}

Infecções por C. psittaci ocorrem em pelo menos 465 espécies de aves, distribuídas em 30 ordens distintas (KALETA; TADAY, 2003). Contudo, os 
psitacídeos (cacatuas, papagaios, periquitos e loris) e columbiformes (pombos) parecem ser os mais afetados. Os psitacídeos, demais aves de companhia, pombos-correio, aves sinantrópicas e selvagens que vivem em áreas urbanas e rurais em todo o mundo devem ser considerados como os reservatórios predominantes da clamidiose aviária (BEECKMAN; VANROMPAY, 2009).

Embora a ocorrência de doença por C. psittaci em aves selvagens seja aparentemente incomum, é possível que elas desempenhem o papel de reservatórios naturais do agente, atuando como fontes de infecção em fazendas, para aves de produção, como perus e patos, com consequências potencialmente devastadoras. A presença de pombos bem como de outras aves silvestres e sinantrópicas pode contribuir para a disseminação da clamidiose aviária para populações de aves de produção, companhia e humanos.

A prevalência da C. psittaci em aves é subestimada em decorrência da falta de diagnóstico laboratorial específico. O questionário epidemiológico aplicado em zoológicos latino-americanos constatou a não disponibilidade de testes diagnósticos rápidos ou de medicações e identificou ainda a ausência de protocolos de quarentena e tratamento, bem como a baixa utilização de exames histopatológicos e dificuldade para a confirmação laboratorial da doença (RASO, 2007).

Os registros de ocorrência de clamidiose aviária são muito escassos nos países da América do Sul onde são relatados casos esporádicos na Argentina, Bolívia, Brasil, Chile, Suriname, Uruguai e Venezuela. Nos demais países, não há informações oficiais (ORGANIZAÇÃO INTERNACIONAL DE EPIZOTIAS, 2004).

Examinando papagaios Amazona spp de três regiões do Brasil, Raso (1999) constatou que de $16,7 \%$ a $56,0 \%$ dos animais, aparentemente saudáveis, eliminavam pela cloaca, de forma intermitente, a C. psittaci. Os testes sorológicos mostraram uma soropositividade variando de $60 \%$ a $100 \%$.

No Brasil, em 2000, ocorreu um surto da clamidiose aviária em papagaios jovens, provenientes de tráfico e mantidos em quarentena, nos quais se observou $96,5 \%$ de mortalidade. As aves sobreviventes não se recuperaram dos sinais clínicos, mesmo após dois tratamentos, e foram eutanasiadas como medida de controle da doença (RASO, 2007). 
Raso et al. (2002) constataram em 26 araras-azuis provenientes de comércio ilegal, que $35 \%$ liberavam a C. psittaci e $50 \%$ eram soropositivas (RASO et al., 2002).

Lima, Raso e Araujo Jr. (2003) examinaram aves sinantrópicas (Columba livia) que habitavam um jardim zoológico em Bauru; encontraram 27,4\% de animais positivos para C. psittaci pela análise por PCR de secreções coletadas da orofaringe.

Cubas e Godoy (2004) observaram que em criatórios e zoológicos brasileiros tem sido encontrada alta prevalência de animais portadores de C. psittaci. A presença do micro-organismo foi comprovada pela PCR aplicada a amostras de orofaringe e cloaca de pombos (Columba livia) de vida livre que habitavam um zoológico brasileiro.

Ao examinar oito espécies de ranfastídeos cativos em um zoológico no município de São Paulo Brasil, Raso (2005) constatou 16\% de soropositividade para C. psittaci pela reação de fixação de complemento. Entretanto, nenhuma ave apresentava qualquer sinal clínico de doença, ou eliminava o micro-organismo.

\subsection{DOENÇA NO SER HUMANO}

No ser humano, a infecção por C. psittaci pode ser assintomática ou apresentar-se como uma pneumonia atípica ou febre de origem desconhecida. Muitos casos provavelmente não são diagnosticados e os possíveis diagnósticos se resumem à detecção da presença de anticorpos. O teste sorológico, comumente utilizado para triagem, não distingue a infecção por C. psittaci de infecções causadas por C. pneumoniae (SILLIS; WHIT, 1990.)

Os casos clínicos de seres humanos infectados por C. psittaci podem ser de duas formas: pneumonia atípica grave ou septicemia tóxica sistêmica sem envolvimento respiratório. Em ambos os casos estão presentes febre, calafrios, 
dores musculares e cefaleias. Também podem ocorrer diarreias, náuseas e vômitos.

O período de incubação da infecção $C$. psittaci é variável, podendo durar de uma a quatro semanas (EUGSTER, 1980). A manifestação da doença pode ser aguda ou insidiosa. À medida que a doença progride, a temperatura do paciente pode aumentar, podendo ter maior gravidade nos pacientes mais idosos. Os casos com envolvimento sistêmico são considerados graves, podendo ocorrer endocardite, miocardite e, possivelmente, complicações renais. Em casos fatais, a taxa de respiração pode aumentar em até três vezes, determinando uma taquipneia grave que leva a uma insuficiência respiratória e à necessidade de se recorrer à ventilação mecânica (WAINRIGHT et al., 1987). Nos casos de sobrevida, a recuperação pode ser prolongada e complicada por quadros de encefalite, meningite, mielite e hepatite (VANROMPAY et al., 1995).

A infecção de seres humanos por $\mathrm{C}$. psittaci pode ser considerada uma zoonose ocupacional tal como foi a resposta da infecção e reinfecção ocorridas em um médico veterinário (GOSEBELL et al., 1999).

Nos EUA, um surto de clamidiose, clinicamente leve, foi descrito em seres humanos que tiveram contato com um grande carregamento de aves infectadas, distribuídas a lojas pet. Sintomatologia branda e infecção assintomática em pessoas expostas a aves infectadas, até então, eram características incomuns desta zoonose (MORONEY et al., 1998).

\subsection{DOENÇA NAS AVES (ORNITOSE)}

Muitas doenças em aves, assim como em outras espécies, são consequências da depressão do sistema imune causado tanto por condições físicas quanto psicológicas. As fontes psicológicas podem ser o estresse ambiental, falta de sociabilização, frustração sexual, maus-tratos ou negligência. $O$ curso da doença 
quando exposto a um agente infeccioso será dependente da estabilidade do sistema imune (NESS, 2006).

O papel do estresse na capacidade de combater infecções bacterianas, virais e parasitárias foi estudado como um cofator potencial de doenças infecciosas. 0 estresse psicológico parece ser capaz de alterar a suscetibilidade de animais a agentes infecciosos, influenciando o aparecimento, curso e resolução de certas doenças. Este assunto é estudado pela psiconeuroimunologia, que aborda as complexas relações entre os fatores psicossociais, o sistema nervoso central, o sistema imune e os agentes infecciosos (BIONDI; ZANNINO, 1997).

As formas de estresse tendem a ser cumulativas, e uma única ocorrência de situação de estresse frequentemente tem pouco efeito clínico sobre a ave hígida. No entanto, quando uma ou mais situações estressantes ocorrem, a ave pode já estar enfraquecida a ponto de ficar clinicamente doente ou vir a óbito (NESS, 2006).

Os sinais clínicos da infecção dependem da espécie, idade e estado imunológico da ave, do grau da infecção, via de transmissão, virulência do sorotipo envolvido e eventual presença de infecções concorrentes (GUERLACH, 1994; FRIEND; FRANSON e CHRISTIAN, 1999; RUPLEY, 1999; CUBAS; GODOY, 2004; CFSPH, 2005; RASo, 2007; SMITH, 2009).

Beer (1988b) descreveu que o período de incubação da clamidiose aviária foi de três dias na infecção artificial e 106 dias na infecção natural. Guerlach (1994) observou um período mínimo de incubação em uma infecção natural de psitaciformes de 42 dias e um período de sete anos em periquitos-australianos.

A doença é classificada nas seguintes formas, baseado na evolução dos sinais clínicos (RASO, 2007):

- Forma superaguda: ocorre geralmente em aves jovens, com óbito em poucas horas, sem sinais clínicos.

- Forma aguda: comumente verificada em psitacídeos, apresenta manifestações clínicas inespecíficas, podendo se observar apatia, sonolência, anorexia, asas pendentes, desidratação, blefarite, conjuntivite e corrimento nasal. Ocorrem ainda alterações respiratórias (rinite, sinusite, dispneia), digestivas (diarreia amarelo-esverdeada), urinária (poliúria), 
reprodutivas (infertilidade, morte embrionária) e, nos estágios terminais, alterações neurológicas, como tremores, convulsões, opistótono e paralisia.

- Forma crônica: sinais clínicos discretos e, consequentemente negligenciados, geralmente caracterizados por emagrecimento progressivo, conjuntivite e discretas alterações respiratórias.

- Forma inaparente: não ocorrem sinais clínicos, sendo comum em aves adultas expostas a sorotipos de média e baixa virulência. Nessa condição, as aves permanecem como portadoras, podendo eliminar os corpos elementares (CE) do agente de forma intermitente por vários meses e, ainda, apresentar alterações inespecíficas como perda de peso, deficiência no empenamento e infecções bacterianas oportunistas.

Rupley (1999) observou que a C. psittaci pode causar infecção localizada e conjuntivite nos fringilídeos, sinal clínico predominante da clamidiose dos patos e gansos. A conjuntivite associada à descarga nasal é característica clássica de clamidiose em pombos domésticos (Columba livia).

Cubas e Godoy (2004) relatam que aves dos gêneros Amazona (papagaios) e Ara (araras), bem como aves jovens, são consideradas mais suscetíveis à infecção aguda fatal por C. psittaci. Os sinais mais comuns em psitacídeos são conjuntivite, diarreia, regurgitação, espirros, dispneia, anorexia, diminuição de peso e depressão (CARVALHO, 2004).

Guerlach (1994) constatou elevada taxa de mortalidade em avestruzes infectados pela C. psittaci.

O estresse causado por superpopulação, higiene precária, alimentação deficiente, alterações ambientais, transporte ou infecções concomitantes pode ativar uma infecção latente, resultando na manifestação clínica da doença (RASO, 2007). 


\subsection{ALTERAÇÕES ANATOMOPATOLÓGICAS}

Não existem alterações macro ou microscópicas patognomônicas da clamidiose aviária. A gravidade das lesões varia de acordo com a evolução da doença e do órgão afetado. Beer (1988b), Friend, Franson e Christian (1999) e Rupley (1999) relatam que as lesões mais comuns incluem aerossaculite, esplenomegalia, enterite, peritonite, pericardite, broncopneumonia e sinusite. Contudo, algumas aves infectadas podem não apresentar qualquer lesão macroscópica.

De modo geral, na necrópsia de aves com clamidiose aviária observa-se baço aumentado e friável, podendo conter ou não focos necróticos esbranquiçados ou petéquias na superfície. O fígado apresenta-se aumentado, friável e de coloração amarelada ou esverdeada, com pequenos focos necróticos na cápsula ou na superfície de corte (RUPLEY, 1999; RASO, 2007). Os pulmões, geralmente estão congestos e a cavidade celomática pode conter exsudato fibrinoso. As membranas dos sacos aéreos podem estar espessadas, opacas e, em alguns casos, recobertas por exsudato fibrinopurulento; o saco pericárdico pode estar inflamado e também podem ocorrer congestão e hemorragia no trato intestinal, especialmente na superfície serosa.

Mohan (1984); Gerlach (1986); Simpson (1996) e Carvalho (2004) observaram necrose pancreática, orquite e ooforite em aves com clamidiose. Guerlach (1994) verificou que aves machos sexualmente ativas infectadas por $C$. psittaci podem apresentar orquite ou epididimite, resultando em infertilidade permanente. Os casos com ooforite são raros.

Nos casos de clamidiose aguda fatal de aves de companhia as alterações histopatológicas são discretas ou inespecíficas (GUERLACH, 1994; RASO, 2007), todavia, a presença de corpúsculos de inclusão ou corpos de Levintal-Collie-Lilie (LCL) é um achado patognomônico. Os corpúsculos LCL podem ocorrer em muitos órgãos, sendo frequentemente comuns em membranas serosas. Na forma grave da doença, ocorre a proliferação intrassinusoidal de células de Kupffer do fígado. 
Rupley (1999) relatou que a clamidiose é uma causa comum de esplenomegalia nos psitaciformes, podendo ocorrer hiperplasia renal e miocardite. Guerlach (1994) referiu a necrose pancreática em periquitos-australianos e pombos infectados pela C. psittaci.

A proliferação de monócitos e a ativação do sistema retículo-endotelial podem ocorrer em órgãos parenquimatosos, particularmente no baço, no fígado e nos rins de aves infectadas por C. psittaci (GUERLACH, 1994). Nas demais formas observam-se com frequência a reação inflamatória e necrose focal no órgão afetado. São observadas hiperplasia das células do sistema mononuclearfagocitário, depleção linfoide, plasmocitose e áreas de necrose no baço. Infiltrados mononucleares e periportais heterofílicos são achados comuns no fígado. A necrose coagulativa multifocal é característica de infecções agudas (RASO, 2007). Nas infecções crônicas há hiperplasia de ducto biliar e de histiócitos, bem como a presença significativa de fibrose e infiltrados mononucleares (RASO, 2007). No fígado, podem ocorrer granulomas de células epitelioides; no pulmão encontra-se pneumonia com proliferação de células epiteliais e capilares nos sacos aéreos bem como edema de células epiteliais com vacuolização e imigração de linfócitos para os tecidos danificados (GUERLACH, 1994).

Os hepatócitos presentes na região centrolobular (zona 3) são mais sensíveis, pois o aporte de sangue chega com baixas concentrações de oxigênio $\left(\mathrm{O}_{2}\right)$, sendo, portanto mais sensíveis aos processos inflamatórios e tóxicos (Figura 1) (STALKER; HAYES, 2007). 


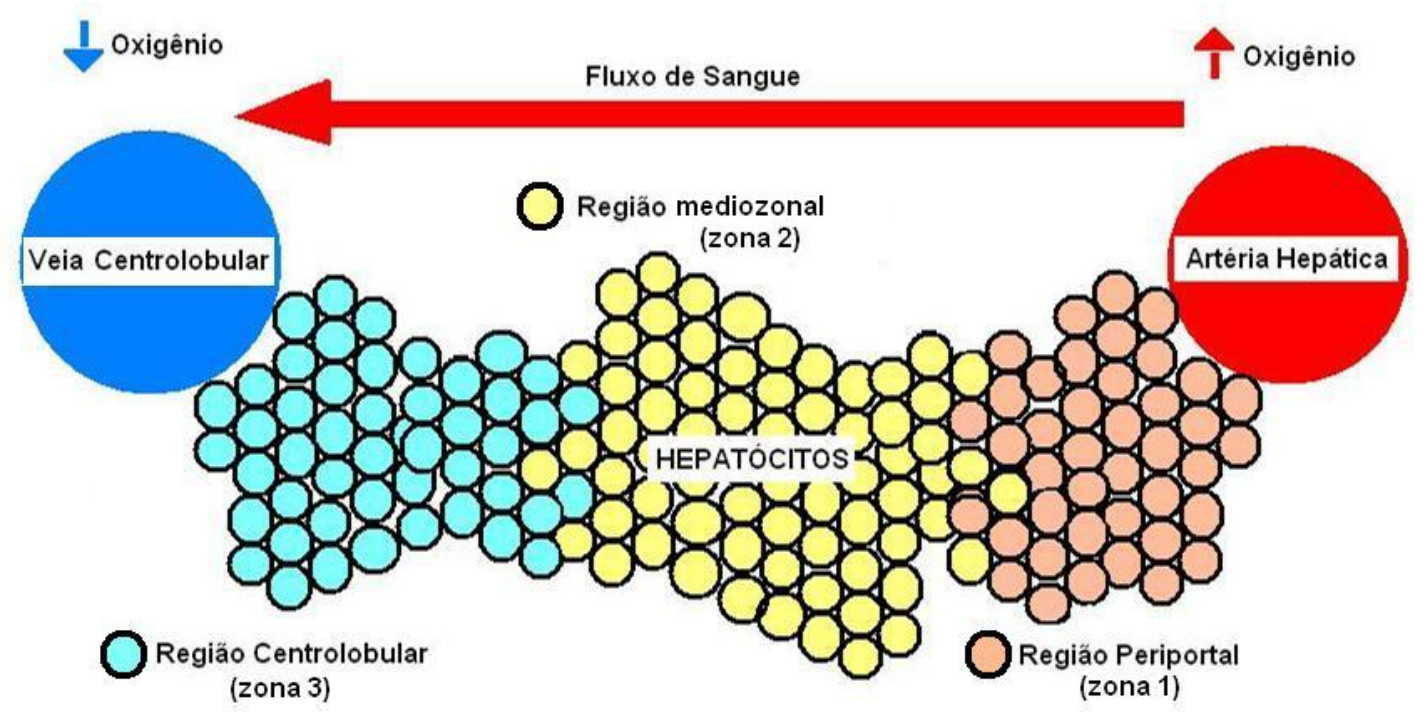

Figura 1 - Esquema de aporte sanguíneo e regiões

Quando ocorre lesão no sistema nervoso central, o exame histopatológico revela meningite (CORREA, 1975; SCANLAN, 1991). Contudo, esta meningite é do tipo não purulenta; infecções secundárias bacterianas, fúngicas e virais podem alterar estas lesões, confundindo-as com as mudanças clamidiais (GUERLACH, 1994).

$\mathrm{Na}$ clamidiose, o rápido diagnóstico envolvendo as espécies sensíveis, testes específicos de detecção e estreita colaboração entre órgãos de saúde pública, médicos e laboratórios de diagnóstico são fundamentais para o controle da doença (GAEDE et al., 2007).

O exame clínico detalhado, associado ao histórico clínico e outros fatores, pode permitir especulações acerca do diagnóstico. No entanto, a confirmação da infecção C. psittaci requer investigações laboratoriais que incluem os exames sorológicos.

Durante a fase aguda da infecção a presença do anticorpo não é facilmente detectada. O teste de aglutinação em látex (MOORE et al., 1991) capaz de detectar anticorpos lgM tem sido utilizado para demonstrar provável infecção. No entanto, grande parte das infecções em aves é subaguda ou crônica, e assim produz mais anticorpos lgG como resposta. Além disso, mesmo após tratamento com antibiótico, 
aves "curadas" podem manter uma titulação alta no teste de fixação de complemento (FC). Deste modo, os testes para anticorpos de anti C. psittaci são mais adequados para estudos epidemiológicos do que para o diagnóstico da infecção em indivíduos (VANROMPAY et al.,1995).

A confirmação da infecção por C. psittaci pode ser obtida pelo isolamento e/ou identificação do micro-organismo. $O$ isolamento é efetuado em amostras de órgãos ou de fezes. Para cultivo celular podem ser utilizados vários tipos de cultura de células como Vero, McCoy, Buffalo Green Monkey ou em embriões de galinha. As amostras podem ser tratadas com combinações de gentamicina, vancomicina e nistatina para reduzir a contaminação por outros micro-organismos. No entanto, o sucesso do isolamento depende da manutenção dos espécimes coletados. Um resultado negativo em cultura não determina com absoluta certeza que uma ave não seja portadora de C. psittaci, uma vez que o agente possui características de liberação intermitente. Nos cultivos celulares, a C. psittaci promove a formação de inclusões visualizadas por coloração de Giemsa ou azul de metileno ou por imunofluorescência.

Outros métodos estão disponíveis para a identificação de C. psittaci sem a necessidade do cultivo celular. Tais métodos incluem a microscopia eletrônica (GRIMES; CLARK, 1996), imunofluorescência direta (VANROMPAY et al., 1994) e testes de detecção do antígeno (THIELE et al., 1992; VANROMPAY et al., 1994; HEWINSON et al., 1997). No entanto, os testes para detecção do antígeno possuem problemas de especificidade podendo haver reações cruzadas.

Os casos são definidos como confirmado, provável ou suspeito. O diagnóstico baseia-se na associação do exame clínico da ave, alterações anatomopatológicas, radiologia, citologia, cultura, sorologia e eletroforese (RUPLEY, 1999; FRIEND; FRANSON e CHRISTIAN, 1999; EUROPEAN COMMISSION, 2002; KHAN, 2006; RASO, 2007; SMITH, 2009).

Rupley (1999) descreveu não existir um teste único que detecte a infecção em todas as aves infectadas ou portadoras e que não resulte em resultados falsopositivos nas aves não infectadas. 
Quanto aos achados de alterações anatomopatológicas associados à clamidiose, Guerlach (1994) descreveu um quadro de leucocitose elevada, com contagem duas a três vezes superior à normal, anemia com decréscimo de hematócrito em 20\%-30\%, heterófilos normais, linfopenia ou contagem normal de linfócitos, monócitos, basófilos e eosinófilos normais, AST (aminotransferase de aspartate) elevada mais que três vezes, CPK (creatinofosfoquinase) elevada mais que duas vezes, LDH (desidrogenase lática) elevada em mais de duas vezes, ligeiro aumento de proteínas totais, ácido úrico normal e ácidos biliares elevados em mais de duas vezes.

Rupley (1999) descreveu leucocitose intensa em psitaciformes grandes infectados pela C. psittaci decorrente de heterofilia, monocitose e basofilia. Nas infecções subclínicas pode ocorrer uma contagem leucocítica normal. Aves pequenas geralmente exibem uma leucocitose suave. Pode-se encontrar presente uma anemia com elevação de AST, LDH, CPK e dos ácidos biliares.

O exame radiográfico de aves com clamidiose revela espaços aerossaculares abdominais ou torácicos com opacidade não homogênea generalizada (RUPLEY, 1999) e esplenomegalia e/ou hepatomegalia (CARVALHO, 2004).

Nos casos suspeitos de clamidiose, os esfregaços de amostras post mortem do fígado, baço, sacos aéreos e pericárdio podem ser corados pela técnica de Stamp, Giemsa, Gimenez, Macchiavello ou Castañeda (GERLACH, 1986; CARVALHO, 2004).

Raso (2007) relatou que as técnicas de coloração citológica apresentam sensibilidade e especificidade baixas e necessitam de técnicos bem qualificados e treinados para identificar corpos elementares que podem ser confundidos com outras bactérias ou como precipitado do corante. 


\subsection{REAÇÃO DE CADEIA DE POLIMERASE (PCR)}

O teste da PCR, aplicado à detecção do DNA da C. psittaci em amostras fecais, tem sido descrito como um procedimento viável (TAKASHIMA et al., 1996). A PCR pode ser realizada rotineiramente para detectar o DNA de C. psittaci em amostras clínicas, incluindo fezes e tecidos. Uma PCR in-house relatada por Hewinson et al $(1991,1997)$ foi superior ao isolamento em cultivo celular e à detecção do antígeno (ELISA).

O uso da PCR aliada a metodologias de colheita para detectar a presença de C. psittaci em aves já foi descrito (HEWINSON et al., 1991; 1997; MESSMER et al., 1997; MORONEY et al., 1998; OLSEN et al., 1998; EVERETT et al., 1999; McELNEA; CROSS, 1999). Em todos os relatos foi detectado o DNA da C. psittaci em amostras de tecidos, fezes e secreções.

A utilização da PCR é descrita como técnica sensível e rápida, superando as técnicas tradicionais de sorologia, cultura e isolamento e apresentando a vantagem de ser utilizada para qualquer espécie animal (MORONEY et al., 1998).

Várias modalidades da PCR têm sido desenvolvidas e validadas para outras espécies de clamídia (SCHEPETIUK et al., 1997; DEAN et al., 1998; MAHONY et al., 2000; DAWELL et al., 2001), tendo como prioridade as espécies mais relevantes para a medicina humana.

Na medicina humana, trabalhos demonstraram que a PCR é mais sensível que as outras técnicas de diagnóstico (NEWHALL et al., 1999; STARY, 2000). Esta metodologia tem sido muito utilizada por apresentar maior rapidez e sensibilidade quando comparada com outras técnicas de diagnóstico.

O dilema sobre as PCRs utilizadas na medicina humana em comparação com as utilizadas para C. psittaci em aves é que o desempenho superior da PCR não pode ser facilmente verificado por um método independente, pois não existe nenhum método tão sensível como PCR. No entanto, é necessária a realização de mais trabalhos nesta área, inclusive para promover normalização entre laboratórios (EUROPEAN COMMISSION, 2002). 
A PCR aplicada ao diagnóstico de clamidiose aviária, devido à sua simplicidade e sensibilidade é, na atualidade, o teste de escolha para o diagnóstico da clamidiose aviária tal como acontece com a cultura e isolamento. Contudo, as amostras devem ser colhidas ao longo de vários dias para aumentar a probabilidade de detecção (EUROPEAN COMMISSION, 2002).

É recomendada a colheita de amostras em três dias consecutivos, armazenagem estas amostras em meio de transporte (EUROPEAN COMMISSION, 2002).

\subsection{TRATAMENTO E CONTROLE}

Felizmente, são raras as fatalidades nos dias de hoje, uma vez que a clamidíase aviária responde bem à antibioticoterapia. No entanto, se o tratamento com antibiótico for insuficiente, pode ocorrer recidiva (GRIMES, 1994).

Para o tratamento de clamidiose aviária, o medicamento de escolha é a doxiciclina, que pode ser utilizada tanto em administração intramuscular, subcutânea ou oral. Outras drogas, como tetraciclina e oxitetraciclina também podem ser utilizadas, administradas pela via intramuscular uma vez por semana, devido ao risco de lesão tecidual local (FLAMMER, 1987).

Algumas quinolonas, como a enrofloxacina, também podem ser utilizadas para o tratamento de aves infectadas. Este grupo de antimicrobianos foi utilizado com sucesso em periquitos, quando o medicamento foi impregnado em alimento fornecido por três semanas (DORRESTEIN, 1989).

As medidas de controle, hoje propostas, incluem quarentena, vigilância e tratamento com antibiótico de aves positivas. Durante o tratamento com antibiótico, a eliminação de materiais infectados (fezes e papel de fundo de gaiola) e a desinfecção são medidas úteis para a eliminação do agente, o que reduz o risco de reinfecção (limpeza de grades, comedouros e poleiros). 
No Reino Unido existem instrumentos legais que permitem o controle de surtos de epidemias causados por C. psittaci, atuando, por exemplo, na linha de aves de produção, em pet shops que vendem animais, nas estações de quarentena ou aviários. Leis semelhantes também existem em outros países, porém, a erradicação ou eliminação da bactéria é praticamente impossível, uma vez que a infecção acomete animais no mundo todo (ex.: aves migratórias). Infecções em aves de companhia e em pombos continuam a representar um perigo significativo para a saúde pública (GRIMES; CLARK, 1986).

O aprimoramento dos métodos de diagnóstico e tratamento, bem como a quarentena das aves e a melhora da higiene no setor avícola têm reduzido a ocorrência de pandemias. Storz (1988) afirmou que o relaxamento na aplicação das medidas de controle pode conduzir ao reaparecimento de uma epidemia de $C$. psittaci e da sua transmissão aos seres humanos.

Ainda não está disponível uma vacina contra a clamidiose. Há muitos esforços para o desenvolvimento de uma vacina de DNA para a imunização de aves de companhia. Vacinas baseadas em plasmídeos de DNA expressando C. psittaci MOMP, inoculadas pela via sistêmica ou local, têm sido testadas em perus. Nestas aves pôde-se observar que as vacinas, baseadas em DNA, evitaram a ocorrência de sinais clínicos graves e diminuíram a liberação ambiental do micro-organismo em perus positivos para o mesmo sorotipo (VANROMPAY et al., 1999).

\subsection{MICROBIOTA}

A microbiota intestinal das aves é composta de inúmeras espécies de bactérias, formando um sistema complexo e dinâmico. As que colonizam o trato intestinal no início tendem a persistir ao longo da vida da ave, passando a compor a microbiota intestinal (FURLAN et. al., 2004). A formação desta microbiota se dá imediatamente após o nascimento das aves e aumenta durante as primeiras semanas de vida (FLEMMING, 2005). 
O número e a composição dos micro-organismos da microbiota intestinal das aves variam consideravelmente ao longo do trato gastrintestinal (TGI). No inglúvio (papo) existe a predominância de lactobacilos produtores do ácido lático e acético, que reduzem o $\mathrm{pH}$ e impedem o crescimento de bactérias. $\mathrm{O} \mathrm{pH}$ no proventrículo e moela é extremamente baixo, e poucas bactérias toleram este ambiente. No duodeno, o pH é neutro, e os micro-organismos colonizam este segmento do intestino delgado, bem como o jejuno e íleo. O ceco é reconhecido como o segmento de maior colonização de micro-organismos, e grande número de bactérias Gram-positivas e negativas está presente neste local (MACARI; FURLAN, 2005).

Menten e Pedroso (2005) referem que as diferenças na microbiota do trato intestinal decorrem de alterações de $\mathrm{pH}$, de secreção enzimática da região, da velocidade de trânsito do bolo alimentar a da concentração de ácidos graxos voláteis.

Nas aves, as bactérias patogênicas atingem o trato digestivo após vencerem a barreira do papo (inglúvio). A existência de um ambiente ácido com pH baixo no papo é muito importante para impedir ou diminuir a colonização de patógenos no trato digestivo das aves. A quantidade alta de Lactobacillus e $\mathrm{pH}$ baixo no papo tem reduzido a ocorrência de Salmonella sp. (HINTON et al., 2000).

Esta variada composição da microbiota intestinal pode ser tanto benéfica quanto prejudicial para o hospedeiro, os efeitos prejudiciais seriam: diarreia, infecções, distúrbios hepáticos, carcinogênese, putrefação intestinal, redução da digestão e da absorção de nutrientes. Já os benefícios estariam vinculados à inibição do crescimento de bactérias patogênicas, estímulos ao sistema imune, síntese de vitaminas, redução da produção de gases e melhor digestão e absorção dos nutrientes (FURLAN et. al., 2004).

As bactérias benéficas produzem enzimas digestivas e metabólitos que neutralizam as toxinas bacterianas; aumentam a imunidade da mucosa intestinal e competem com as bactérias patogênicas (FERKET, 1990).

A Escherichia coli (E. coli) é uma bactéria Gram-negativa da família Enterobacteriaceae, a qual por muito tempo foi considerada um habitante comensal da microbiota entérica de diversas espécies animais, sem grande potencial 
patogênico. Essa visão mudou progressivamente ao se reconhecerem diversas afecções entéricas e extraintestinais, causadas por $E$. coli de sorotipos específicos possuindo diversos fatores de virulência característicos (SUSSMANN, 1997).

\subsection{RESISTÊNCIA BACTERIANA}

A tetraciclina e a eritromicina foram utilizadas durante décadas para tratar infecções de humanos por clamídias. Assim, esses antibióticos são utilizados em larga escala, o que indica que a resistência clínica a eles ainda não é um grande problema (MCORIST, 2000).

A eficácia dos macrólidos, tais como eritromicina e azitromicina, está relacionada à sua capacidade para atingir concentrações intracelulares elevadas, particularmente em macrófagos, distribuindo-se uniformemente em fagossomos e lisossomos (TULKENS, 1991; LABRO, 1996). As tetraciclinas também penetram nas células, mas a sua localização intracelular não é bem conhecida (MCORIST, 2000). Os antibióticos betalactâmicos (penicilinas e cefalosporinas) ou aminoglicosídeos (gentamicina) penetram lentamente nas células, e sua eficiência contra clamídias é moderada ou baixa.

Há substanciais dificuldades técnicas para a mensuração da resistência da $C$. psittaci aos antibióticos. Suchland, Geisler e Stamm (2003) relataram que a concentração inibitória mínima (MIC) de vários antibióticos contra diferentes espécies de clamídias depende do laboratório, da estirpe utilizada, do tempo entre a infecção e a utilização do antibiótico, da concentração do inóculo e da via de administração utilizada. Em geral, a resistência in vitro não se correlaciona com o aparente resultado clínico em aves infectadas.

Em geral, as bactérias intracelulares, como clamídias, rickettsias ou lawsonia, têm padrões semelhantes de sensibilidade aos antibióticos. A resistência aos antibióticos relatada em casos de C. trachomatis (JONES et al., 1990) foi 
contestada (RIDGWAY, 1997). Posteriormente, uma estirpe da mesma espécie, resistente à concentração de 64 microgramas por $\mathrm{mL}$ de tetraciclina, foi descrita na França por Lefevre e Lepargneur (1998). Somani et al (2000) descreveram nos Estados Unidos três isolamentos de $C$. trachomatis que apresentaram resistência à poliquimioterapia, doxiciclina, azitromicina e orfloxacina em concentrações superiores a $4 \mu \mathrm{g}$ por $\mathrm{mL}$. Em Israel, testes in vitro com 50 isolados clínicos de Chlamydia trachomatis demonstraram que a concentração mínima inibitória deve ser acima de $4 \mathrm{ug} / \mathrm{mL}$ para doxiciclina e tetraciclina encontrada em $8 \%$ e $4 \%$, respectivamente, das estirpes isoladas (SAMRA et al., 2001).

Contudo, a resistência aos antibióticos adquiridos por C. psittaci até agora não tem sido um problema clínico para o tratamento de clamídias, embora seja um grande problema para bactérias que não são intracelulares.

Primeiramente sugeriu-se que pelo fato de residirem permanentemente dentro de células, estas bactérias seriam incapazes de adquirir genes de resistência aos antibióticos. Os agentes patogênicos intracelulares Coxiella burnettii e C. trachomatis transportam plasmídeos, que teoricamente são capazes de transmitir genes de resistência aos antibióticos; no entanto, a sua função ainda não é totalmente conhecida. Os genes de resistência aos antibióticos transportados em plasmídeos aparentemente ficam indisponíveis para clamídias. Contudo, as clamídias parecem ter sucesso em adquirir ADP/ATP translocases de plantas, o que sugere que a transferência horizontal de genes estranhos às clamídias é viável, pelo menos ao longo do tempo de escalas evolutivas (KOONIN et al., 2001). Em segundo lugar, as bactérias intracelulares que transportam genes de resistência aos antibióticos poderiam ter sua viabilidade reduzida (JONES et al., 1990), conforme indicado em notícia não confirmada de resistência à tetraciclina em infecção por $C$. trachomatis. Em terceiro lugar, o desenvolvimento da resistência às tetraciclinas ou macrólidos em bactérias extracelulares ocorre de maneira ativa e exige significativa energia metabólica das bactérias. Esta energia pode não estar tão prontamente disponível no caso de bactérias intracelulares (MCORIST, 2000).

A aquisição gradual de resistência aos antibióticos por pequenas mutações, por exemplo, a RNA polimerase, que afeta a rifampicina ou DNA girase, que afeta 
as quinolonas, pode ser facilmente alcançada por passagens seriadas em cultivo celular. Desta forma, a resistência da C. trachomatis L2 para várias fluoroquinolonas foi aumentada em até 1.000 vezes por mutação em gyrA conducente a uma substituição para isoleucina na posição 83 em DNA girase (DESUS-BABUS et al., 1998; MORRISSEY et al., 2002). No entanto, não foi possível aumentar a resistência da $C$. pneumoniae às fluoroquinolonas por passagens seriais (MORRISSEY et al., 2002). A eficácia de antibióticos para erradicar infecções crônicas por clamídias, como por exemplo, com a $C$. pneumoniae, é incerta e provavelmente depende do grau de atividade metabólica da bactéria.

Atualmente, a resistência às principais terapêuticas com antibióticos no tratamento de infecções agudas em humanos não é um problema significativo. Os médicos estão em uma situação "confortável", porém há a necessidade de estarem vigilantes, como já demonstrado recentemente pelo surgimento de $C$. suis resistente às tetraciclinas em Nebraska (LENNART et al., 2001). 


\section{JUSTIFICATIVA}

Diante da gravidade da doença, do risco à saúde pública, do caráter de doença ocupacional e de poucos dados de pesquisa direcionados ao tema, foi delineado o presente estudo, desenvolvido em uma clínica veterinária particular no Município de São Paulo, especializada no atendimento de animais silvestres. 


\section{OBJETIVO GERAL}

O presente estudo compreende duas etapas.

\subsection{ETAPA 1}

Determinar o perfil da ocorrência da clamidiose em aves de companhia, atendidas em clínica veterinária particular no Município de São Paulo.

Nesta etapa, os objetivos específicos são:

- Caracterização dos proprietários participantes utilizando questionário para avaliação de comportamento, manejo e higiene dos animais.

- Determinação dos riscos de saúde pública e fatores predisponentes à doença.

\subsection{ETAPA 2}

Avaliar um protocolo de tratamento de aves de companhia, naturalmente infectadas com C. psittaci, obtidas no comércio.

Os objetivos específicos desta etapa são:

- Avaliar aspectos de resposta ao tratamento, impacto na microbiota bacteriana em conjunto com as alterações hepáticas anatomopatológicas e condição de portador de 32 aves naturalmente infectadas. 


\section{MATERIAL E MÉTODOS}

O presente estudo foi realizado na Clínica Veterinária Wildvet, localizada na Rua Casa do Ator, 657, Vila Olímpia, no Município de São Paulo (SP), CEP 04546002. A clínica foi fundada em março de 2003, é especializada no atendimento de animais exóticos e silvestres e conta com mais de dois mil e seiscentos clientes cadastrados desde sua fundação.

O trabalho foi subdividido em duas etapas: no primeiro momento foi elaborado um questionário que passou a ser aplicado aos clientes que traziam suas aves pela primeira vez na clínica; na segunda fase foi avaliado um protocolo de tratamento efetuado em aves naturalmente infectadas.

\subsection{PRIMEIRA ETAPA: QUESTIONÁRIO}

Visando estabelecer o comportamento e o conhecimento dos proprietários em relação às suas aves de companhia, o questionário foi elaborado, testado e aplicado aos indivíduos que estavam utilizando os serviços da clínica pela primeira vez.

\subsubsection{Questionário aplicado}

As questões foram elaboradas, considerando-se variáveis que poderiam influenciar o comportamento do proprietário de aves, tendo como base a teoria social cognitiva (BANDURA, 2004) ${ }^{1}$. Foram abordadas duas áreas de interesse:

\footnotetext{
${ }^{1}$ Alguns autores denominam esta etapa inicial de "teste de comportamentos iniciais", por referir-se à avaliação de comportamento do público-alvo antes da implementação de ações educativas.
} 
a) nível de conhecimento do proprietário sobre a clamidiose;

b) identificação de fatores predisponentes à ocorrência da doença, relacionados ao manejo e higiene dos animais.

No pré-teste (LEITE, 2008), o modelo de questionário, constituído por questões fechadas e semiabertas, foi aplicado de maneira aleatória em dez proprietários de aves que procuraram o serviço da clínica em março de 2008. A análise dos resultados permitiu a elaboração da forma final do questionário aplicado então a 100 novos proprietários durante a primeira consulta, no período de abril a dezembro de 2008 (Apêndice A).

O questionário abordou perguntas básicas em relação à higiene e manutenção da gaiola, conhecimento sobre zoonoses de origem aviária e sobre a saúde dos donos.

5.1.2 Avaliação do questionário aplicado

A análise do conteúdo e das informações das respostas obtidas (WHORTHEN et al., 2004; ROSA; ARNOLDI, 2006) foi transcrita para uma planilha de dados, que deu origem ao quadro final com os respectivos percentuais.

\subsection{SEGUNDA ETAPA: AVALIAÇÃO DE UM PROTOCOLO DE TRATAMENTO}

Visando testar a eficácia e estabelecer impacto do tratamento preconizado para C.psittaci aplicado em um grupo de aves naturalmente infectadas. 


\subsubsection{Animais}

Foram adquiridas 32 aves domésticas com quatro a cinco meses de idade, da espécie Nymphicus hollandicus, comumente chamadas de calopsitas. Vinte e cinco aves eram provenientes de um distribuidor localizado na cidade de Araras (SP), cinco foram adquiridas em duas lojas comerciais da cidade de São Paulo (SP) e duas de um criador de São Bernando do Campo (SP).

Todos os procedimentos deste experimento foram aprovados pela Comissão de Bioética da FMVZ - USP.

\subsubsection{Acomodação e limpeza}

As aves foram distribuídas de maneira aleatória em dois viveiros sobrepostos, onde ficaram em descanso por duas semanas, até o início do estudo (Figura 2). Esse período de contacto das aves visou promover a disseminação da C. psittaci para garantir a positividade do grupo. A alimentação adotada foi constituída por mistura de sementes próprias para calopsitas e acesso a água mineral ad libitum. 


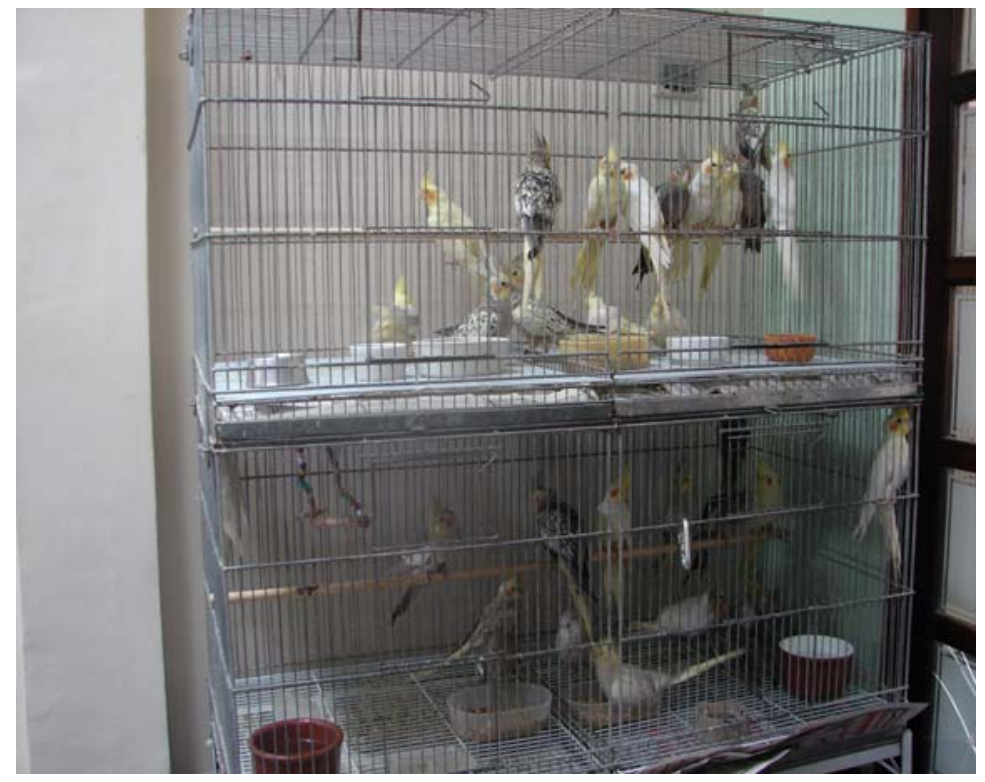

Figura 2 - Aves no período de descanso.

O local de acomodação era bem arejado e submetido à higienização três vezes ao dia. Para a limpeza e manutenção das gaiolas, foram utilizados equipamentos de proteção individual (EPI), como luva, gorro, máscara e aventais descartáveis e desinfetantes à base de amônia quaternária.

\subsubsection{Identificação dos animais}

No dia zero (D0), as aves foram identificadas com a aplicação de anéis numerados sequencialmente, os quais foram colocados na pata esquerda, região do tarso, com o auxílio de alicates e contenção física da ave (Figura 3). 


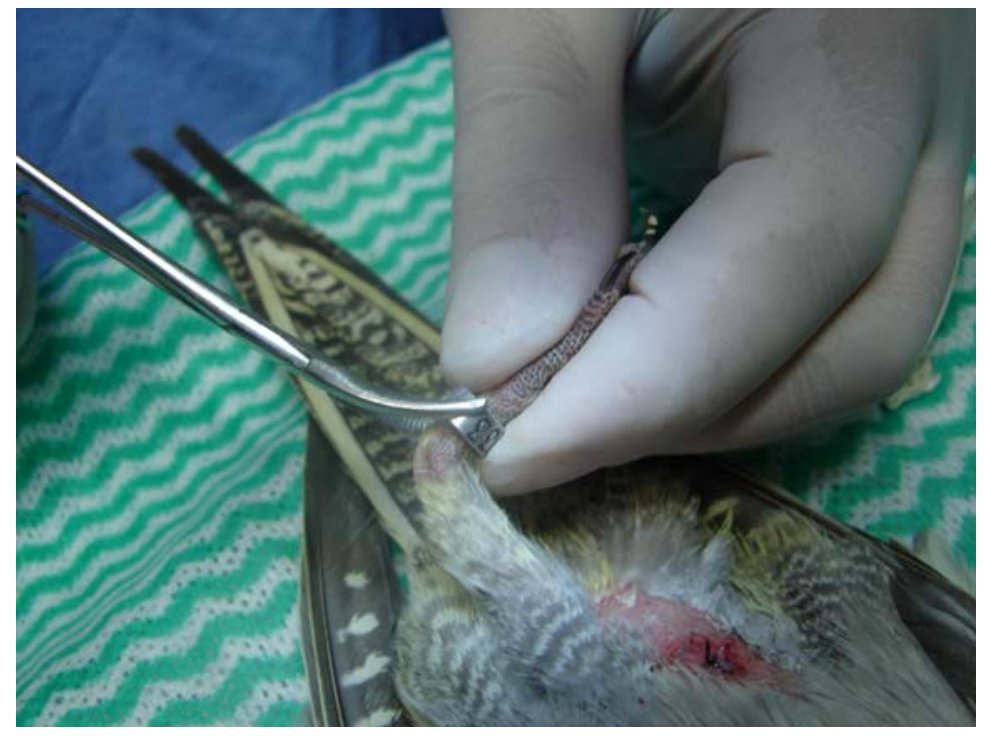

Figura 3 - Procedimento de identificação das calopsitas

5.2.4 Formação dos grupos experimentais

No dia zero, as aves previamente identificadas foram separadas de forma aleatória em pares e acondicionadas em gaiolas (Figura 4); os pares foram formados por calopsitas de cores diferentes para facilitar a atividade de observação e identificação (Figuras 5 e 6). Foram utilizados 26 animais no grupo de tratamento e seis no grupo controle. 


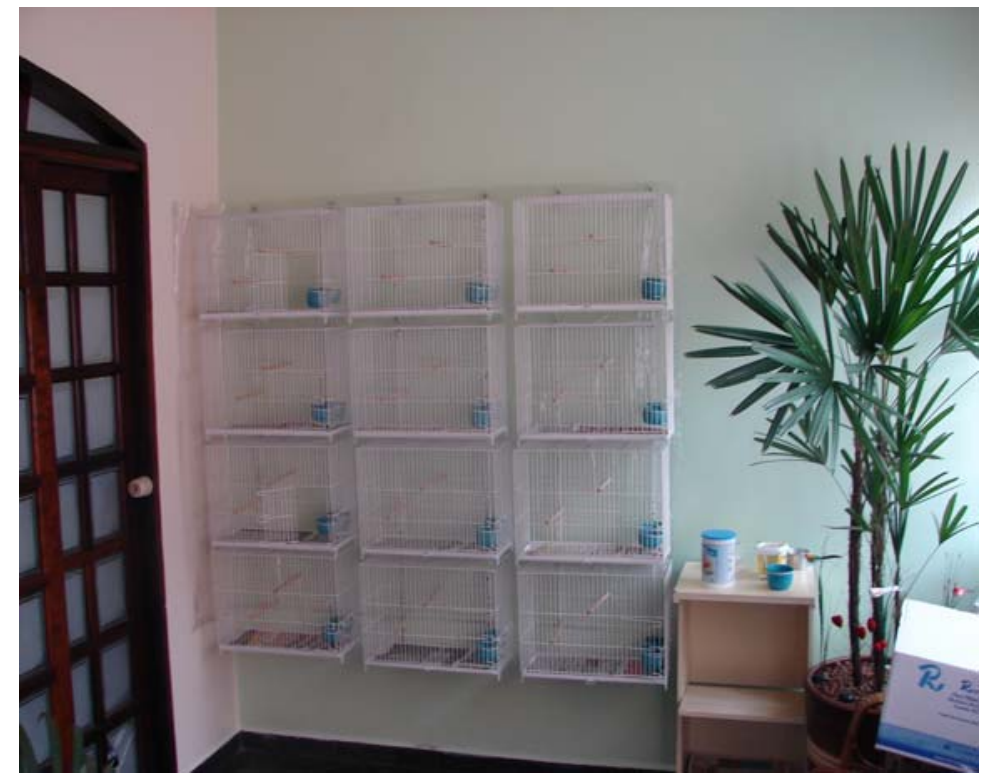

Figura 4 - Gaiolas e ambiente de trabalho

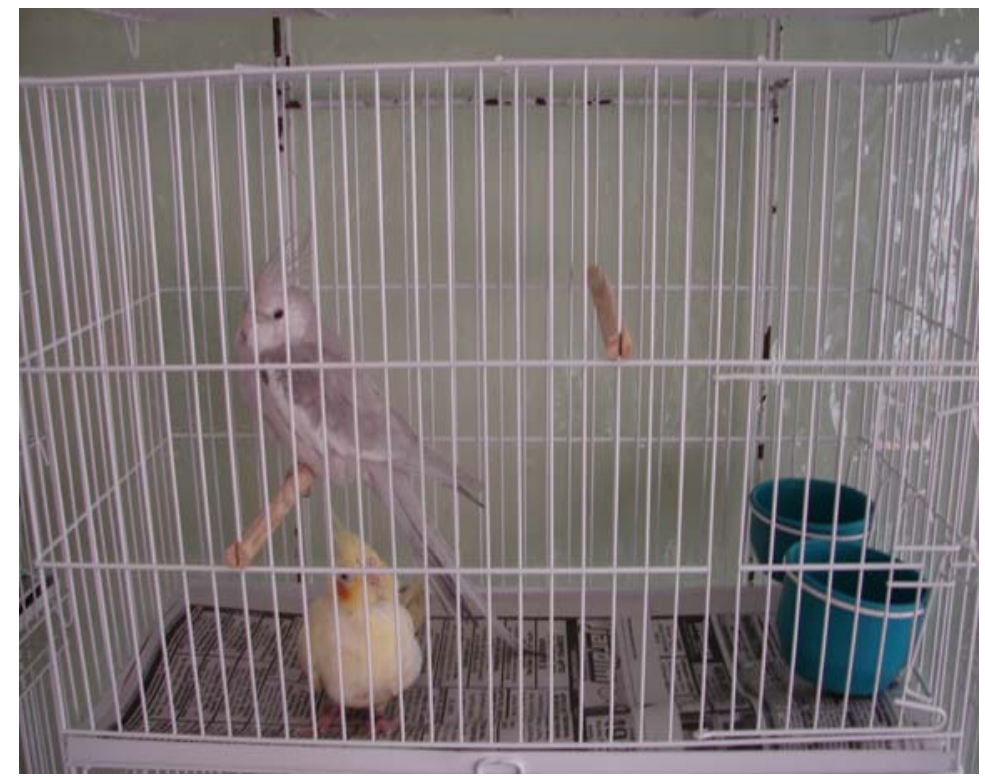

Figura 5 - Pares de calopsitas

O grupo submetido ao tratamento foi mantido isolado em sala diferente do grupo controle para evitar qualquer possibilidade de contaminação entre eles. As atividades foram realizadas no grupo tratado e em seguida, após descarte do material utilizado e troca de EPI, procedia-se o manejo do grupo controle mantido em outro ambiente. 


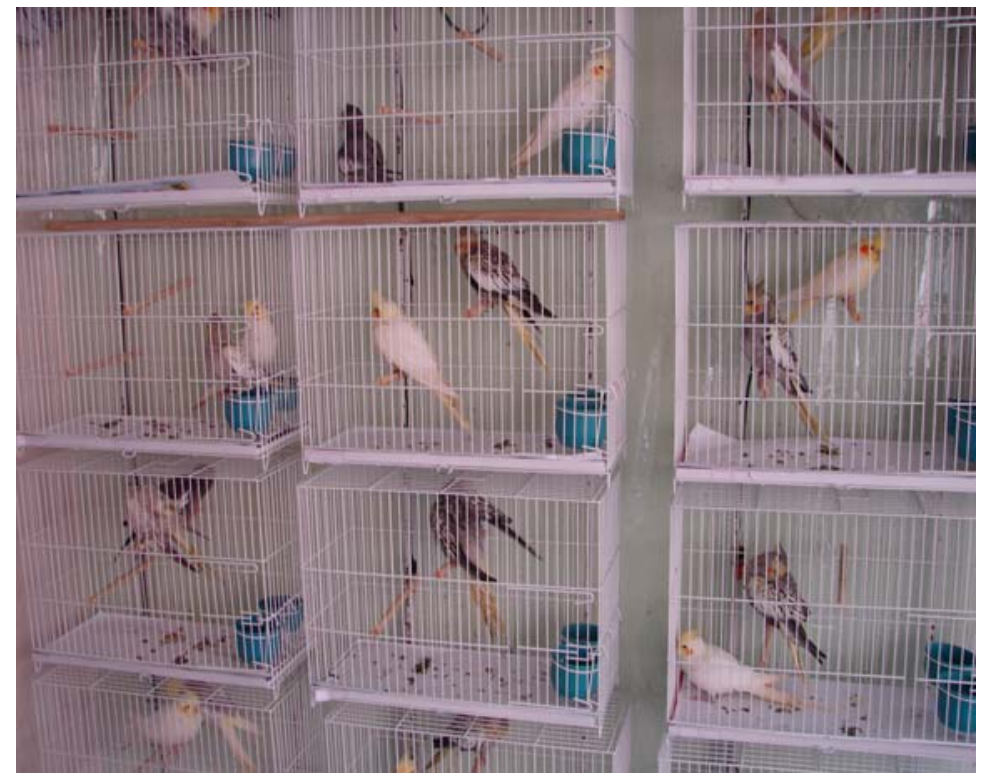

Figura 6 - Visão geral das gaiolas utilizadas

\subsubsection{Fluxograma experimental}

As 32 aves ficaram em descanso durante duas semanas até o momento da primeira biópsia hepática realizada no dia zero (D0), quando foram pesadas, identificadas e separadas. Nos dias D3, D5 e D7 foram colhidos os swabs de cloaca para a PCR, e no D7 também foi colhido um swab de cloaca para cultura.

Após a primeira colheita (Figuras 7 e 8), as aves foram divididas em dois grupos (tratamento e controle), e o tratamento teve início no D15 e durou 45 dias, estendendo-se até o D60. Ao término foram realizadas novas colheitas com swabs de cloaca para PCR nos D65 e D67. No D69 foram efetuados os últimos swabs de cloaca para PCR, cultura e biópsias hepáticas no grupo tratado. Mesmo procedimento foi adotado no D70 no grupo controle (Figura 7). 


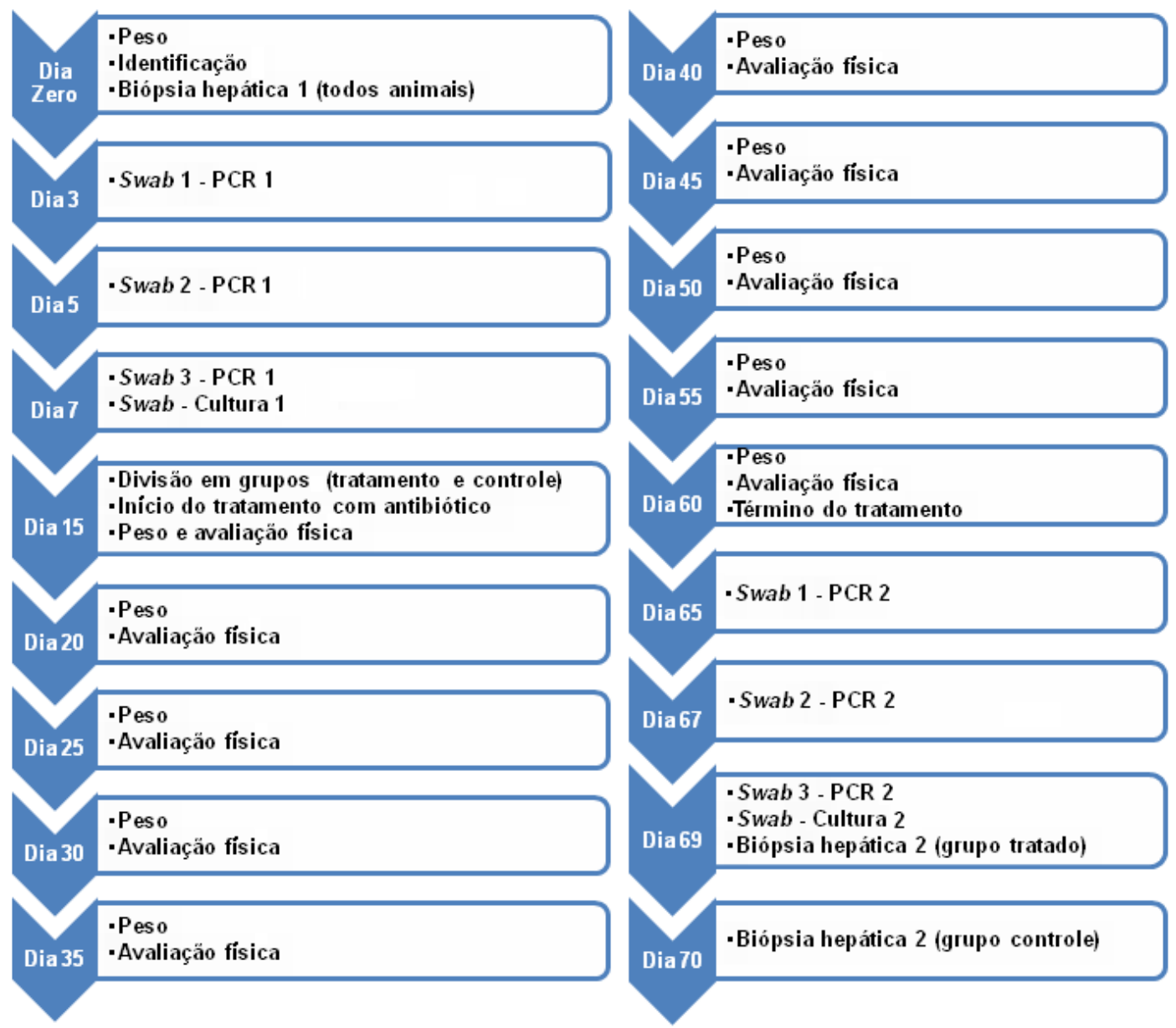

Figura 7: Fluxograma de atividades experimentais

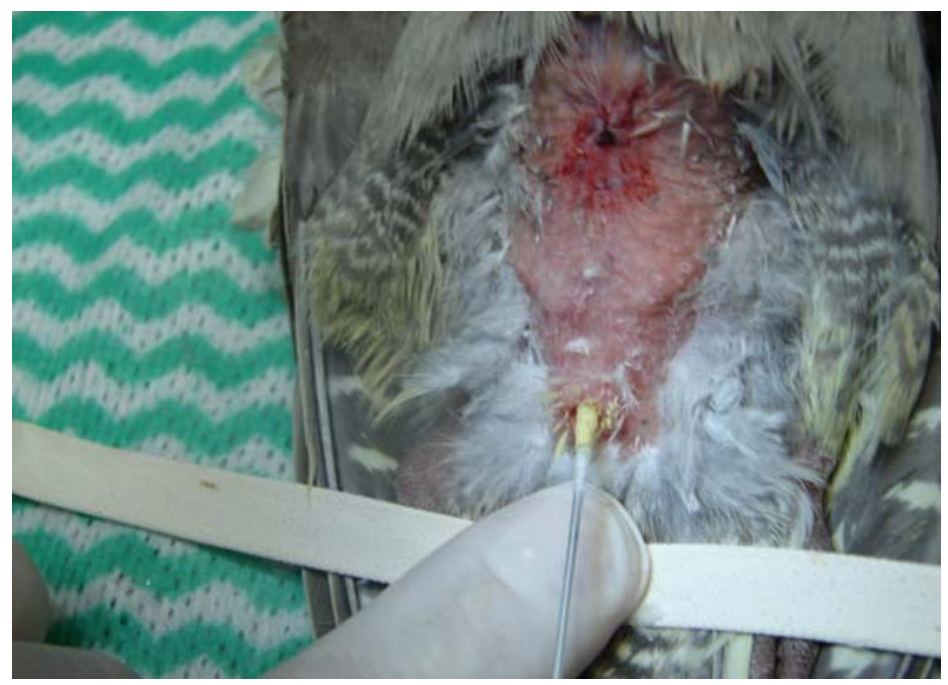

Figura 8 - Swab de cloaca para colheita de material (vista ventro-dorsal) 


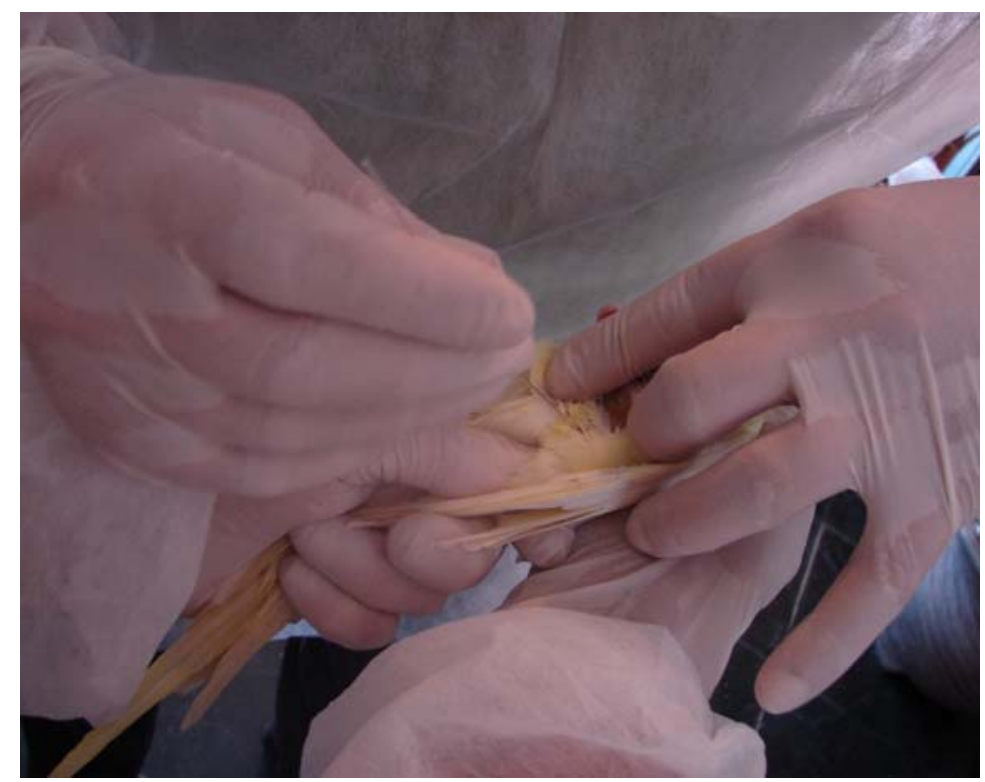

Figura 9 - Swab de cloaca para colheita de material (vista látero-lateral)

\subsubsection{Biópsia hepática}

A biópsia hepática foi realizada em centro cirúrgico por laparoscopia, que permite uma visualização abrangente da anatomia topográfica das vísceras (BUNCH et al., 1985; MARTIN, 1993). O tempo do procedimento foi de aproximadamente 10 a 15 minutos por ave, e para a biópsia foram utilizados três minutos. Devido à preparação do centro cirúrgico, limpeza e esterilização do material (Figura 9), as aves foram divididas em dois grupos, um trabalhado pela manhã e outro à tarde. No final do tratamento, para evitar qualquer possibilidade de contaminação, a biópsia do grupo controle foi realizada no dia seguinte ao do grupo tratado. 
Após jejum total de seis horas, as aves foram contidas fisicamente, receberam a aplicação de vitamina $\mathrm{K}^{2}$ e a seguir foram anestesiadas pela inalação de isofluorano e oxigênio, aplicados com máscara específica.

Após a retirada de penas na região situada entre o término do esterno e a cloaca, foi realizada a incisão na pele, dois milímetros abaixo do esterno em direção à cloaca, com uma tesoura Iris reta (marca Edlo, $15 \mathrm{~cm}$ ), na linha média da região "abdominal". Após abertura da linha alba (Figura 10), a gordura celomática foi rebatida, em direção ao lado direito, com o auxílio de pinças anatômicas de uso oftalmológico. Procedeu-se então o pinçamento do lobo direito do fígado para aproximá-lo da incisão, e com auxílio de uma pinça de iridectomia, foi retirada uma amostra do fígado de aproximadamente $2 \mathrm{~mm}$.

O mesmo procedimento de contenção física e química foi realizado para a segunda biópsia no final do tratamento (D69 e D70). As amostras pareadas foram enviadas para exame histopatológico.

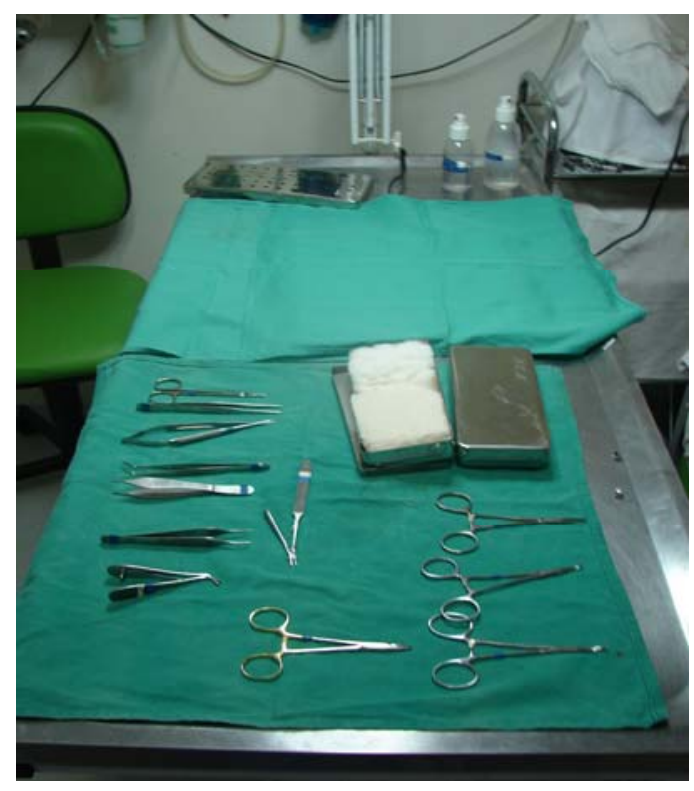

Figura 10 - Material cirúrgico empregado na biópsia hepática

\footnotetext{
${ }^{2}$ Hipovita K - Laboratorio Ibasa Ltda. Fórmula: Vitamina K hidrossolúvel 150mg; Veiculo q. s. p. 100mL.
} 


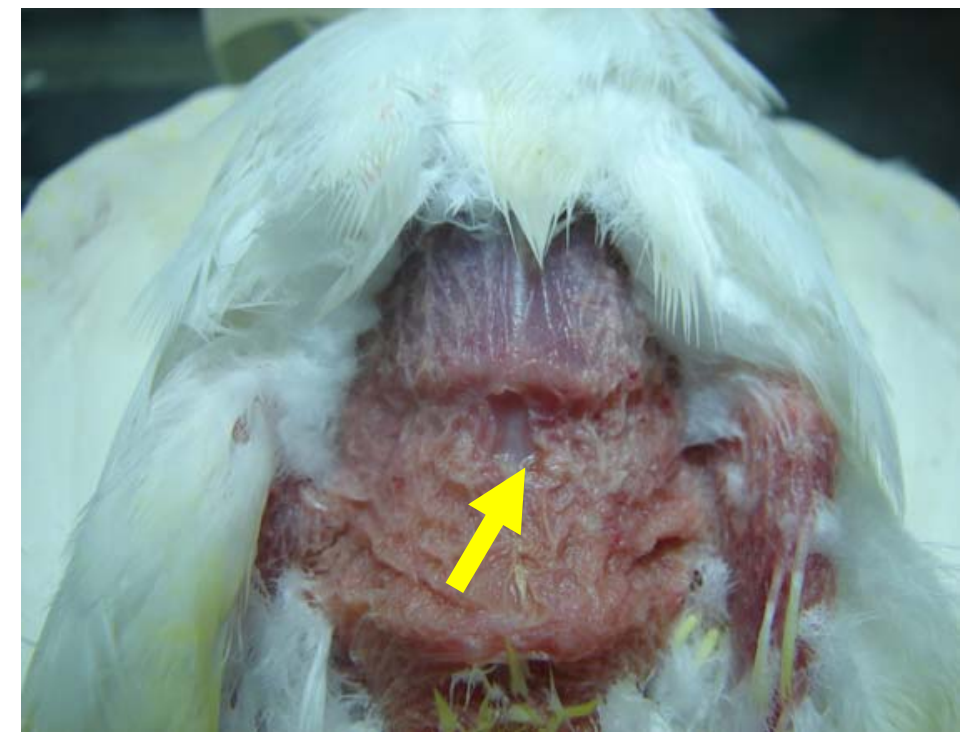

Figura 11 - Visualização da linha alba

\subsubsection{Material para PCR e cultura}

A reação de cadeia de polimerase (PCR) para avaliação da ocorrência de Chlamydophila psittaci foi realizada com o material recolhido da cloaca das aves segundo procedimento descrito por Raso (1999). As colheitas prévias ao tratamento foram efetuadas em D03, D05 e D07, e após o tratamento foram realizadas nos dias experimentais D65, D67 e D69.

$\mathrm{Na}$ aplicação de swabs destinados à PCR e cultura, as aves foram contidas fisicamente (Figura 11), e amostras foram colhidas da porção inicial da cloaca. 


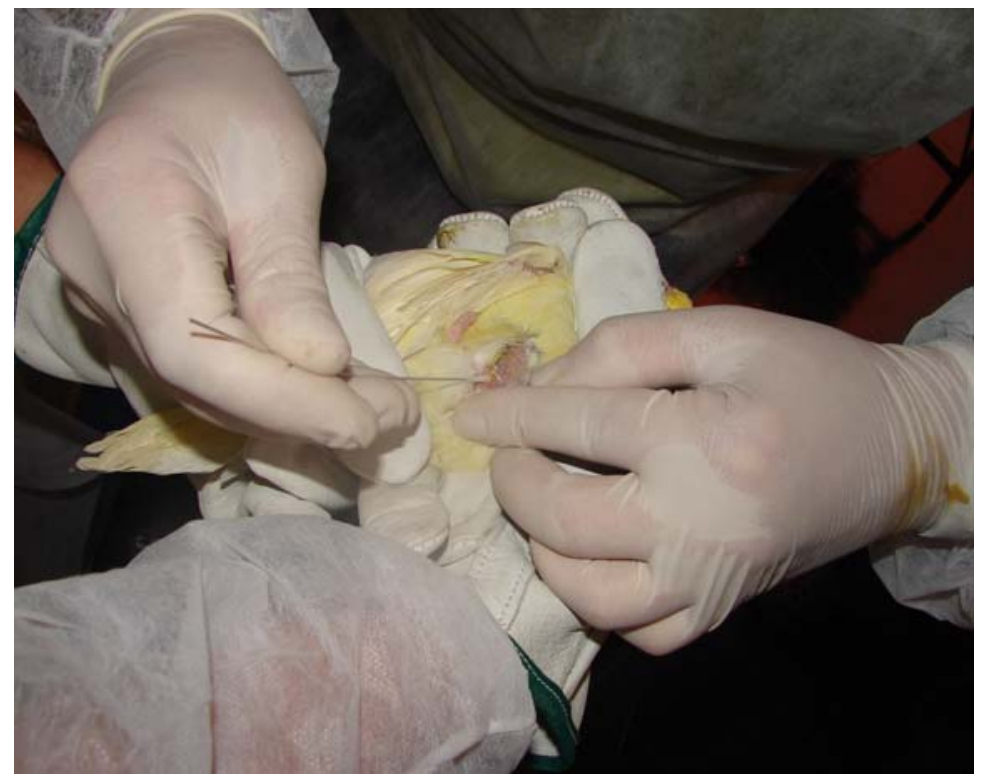

Figura 12 - Contenção física e colheita de material

As colheitas para PCR foram repetidas três vezes em intervalos de 48 horas. As três amostras animais foram acondicionadas em um mesmo Eppendorf estéril com $1 \mathrm{~mL}$ de etanol, devidamente identificado e mantido em temperatura ambiente $\left(23^{\circ} \mathrm{C}\right)$ até o momento do processamento no laboratório do Departamento de Patologia Animal (VPT) da Faculdade de Medicina Veterinária e Zootecnia da Universidade de São Paulo (FMVZ-USP). Um Eppendorf foi designado para as amostras anteriores ao tratamento (D03, D05 e D07) e outro para as posteriores (D65, D67 e D69).

As amostras destinadas à cultura foram colhidas em D07 e D69, acondicionadas na embalagem original do swab, identificadas, mantidas sob refrigeração e encaminhadas imediatamente para processamento laboratorial Labvet $^{3}$.

\subsubsection{Avaliação histopatológica}

\footnotetext{
${ }^{3}$ Lab\&Vet ${ }^{\circledR}$ laboratório de análises clínicas e anatomia patológica veterinária. Av. Escola Politécnica, 4445 SP, CEP 05350-000, Telefone: (11) 3719-2297
} 
Para que fosse considerada representativa, a biópsia deveria conter pelo menos cinco tratos portais (CRAWFORD et al., 1998). Já que todas as lesões fundamentais acometem preferencialmente a zona 3, também foram consideradas como representativas as biópsias que continham pelo menos cinco veias centrolobulares.

Os materiais da primeira e segunda biópsias foram encaminhados para exame histopatológico, acondicionados em formaldeído 10\% tamponado e encaminhados para análise no Laboratório de Histologia do Departamento de Patologia FMVZ/USP. Todos os fragmentos teciduais foram submetidos ao método convencional de preparação de lâminas histológicas. As peças passaram pelos processos de desidratação e diafanização, banho em parafina líquida, inclusão em bloco, e posterior corte em micrótomo rotativo. Os cortes de aproximadamente $4 \mu \mathrm{m}$ de espessura foram posteriormente submetidos ao método de coloração pela Hematoxilina \& Eosina (PROPHET et al., 1992).

Uma vez obtidas as lâminas, foi realizada a avaliação histopatológica de todos os fragmentos teciduais, e os diagnósticos morfológicos relativos às alterações hepáticas foram indexados conforme preconizado por Kleiner et al (2005).

As lâminas foram examinadas de forma cega, sem que o patologista tivesse conhecimento do grupo experimental especifico. Os critérios adotados para a interpretação dos exames pontuam as lesões da seguinte forma: 0 - Nenhuma alteração; 1 - Alteração leve; 2 - Alteração moderada e 3 - Alteração Intenso.

\subsubsection{Protocolo de tratamento}

O protocolo de tratamento seguiu a recomendação descrita no Manual para Chlamydophila psittaci, do National Association of State Public Health Veterinarians - ASPHV (NATIONAL ASSOSSIATION OF STATE PUBLIC HEALTH VETERINARIANS, 2009), que preconiza a dose de doxiciclina (25-35mg/kg/dia), para calopsitas, via oral, durante quarenta e cinco dias consecutivos. 
Para o cálculo de dosagem de medicamento foi adotada a média de 80 gramas/ave, levando-se em conta o peso inicial dos animais. A dose administrada foi de 2,4mg/dia/animal. As aves foram contidas fisicamente (Figura 12), e a medicação foi administrada $(0,1 \mathrm{~mL}$ de solução oral de doxiciclina $2,4 \%)$, via sonda esofágica, diretamente no inglúvio. O grupo controle recebeu diariamente $0,1 \mathrm{~mL}$ de solução salina estéril. Foram produzidas 31 sondas esofágicas de metal aço inox para o procedimento individual.

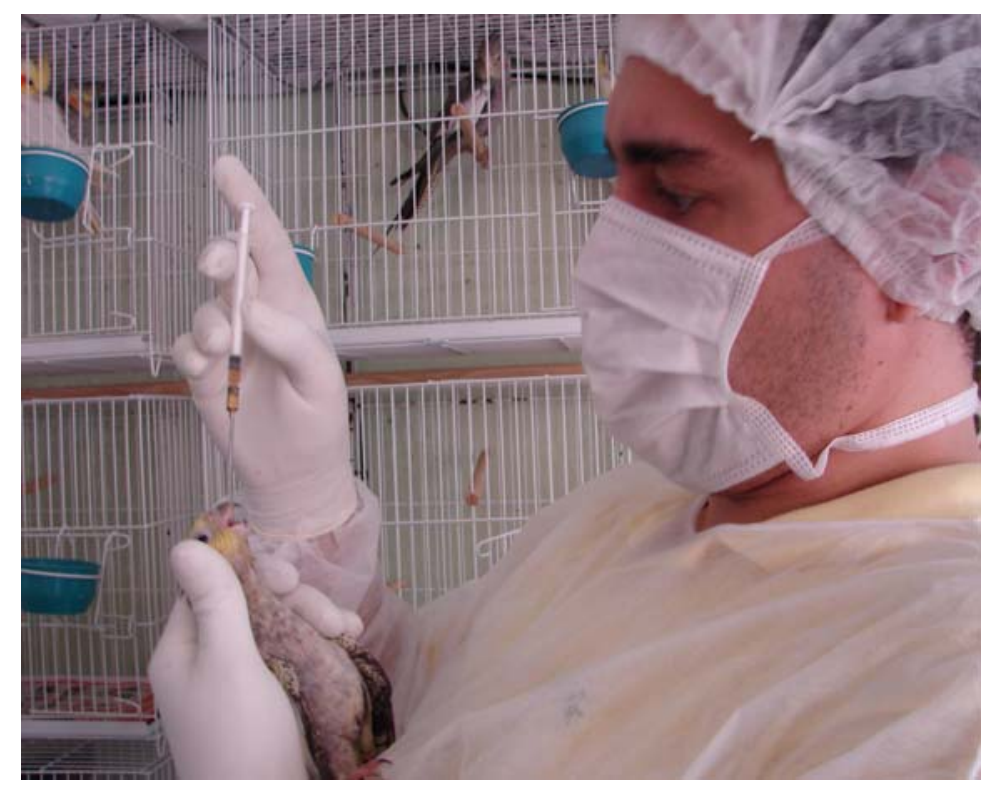

Figura 13 - Administração da medicação

\subsubsection{Controle de peso}

A partir do momento D15, após a realização da primeira biópsia hepática, os animais foram pesados (Figura 13) e examinados fisicamente a cada cinco dias. Os dados referentes ao peso e demais anotações de interesse foram catalogados em planilha de acompanhamento individual (Apêndice B). 


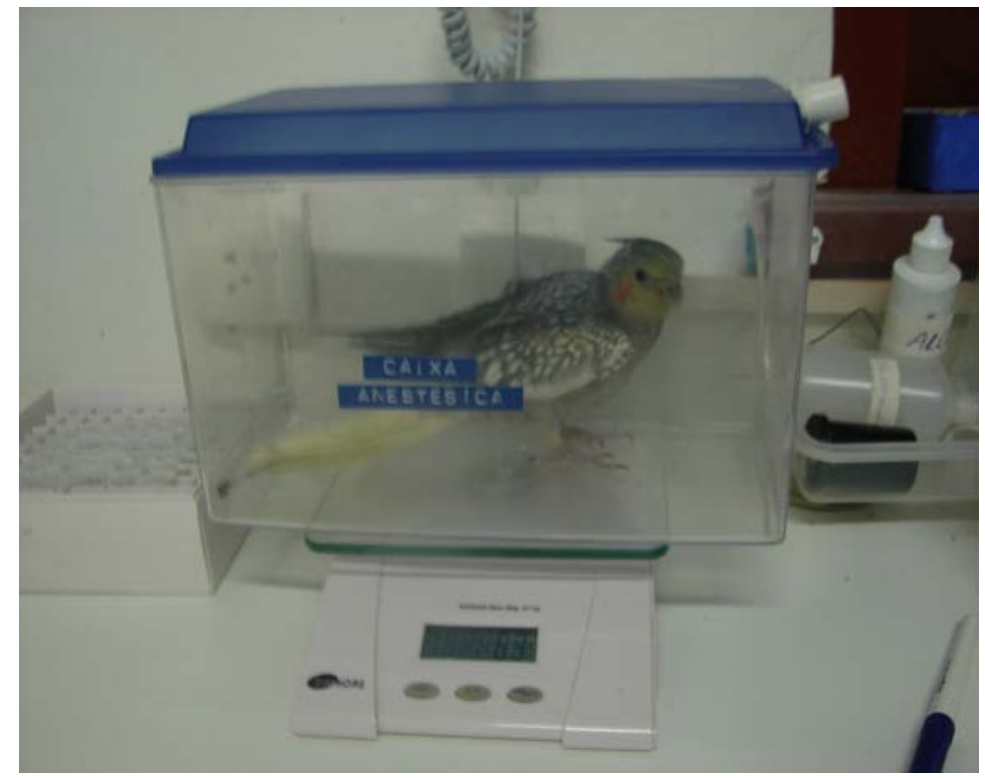

Figura 14 - Pesagem das aves

\subsubsection{Análise estatística}

Os registros de controle de peso e avaliações histopatológicas foram armazenados em banco de dados (Excel) e posteriormente as análises foram efetuadas com o software SPSS ${ }^{\circledR}$ versão 9 . O nível de significância adotado foi 0,05 .

A comparação das médias do peso dos animais foi efetuada pelo teste $T$ de Student, pois esta variável apresentou distribuição normal. $\mathrm{Na}$ análise estatística das biópsias hepáticas, devido à distribuição dos resultados não ter sido normal, foram aplicados o teste de Wilcoxon para os resultados intragrupos e o teste de Mann-Whitney para os resultados entregrupos. 


\section{RESULTADOS E DISCUSSÃO}

Os resultados obtidos seguem a abordagem sugerida na elaboração das etapas, iniciando com a aplicação de questionário em proprietários de aves.

\subsection{CARACTERIZAÇÃO DOS PROPRIETÁRIOS PARTICIPANTES}

Foram entrevistados 100 proprietários de aves que passavam por consulta clínica pela primeira vez. As informações relativas às alterações clínicas das aves foram avaliadas (questões 1 a 5 do Apêndice $A$ ), e as respostas podem ser visualizadas no quadro 1.

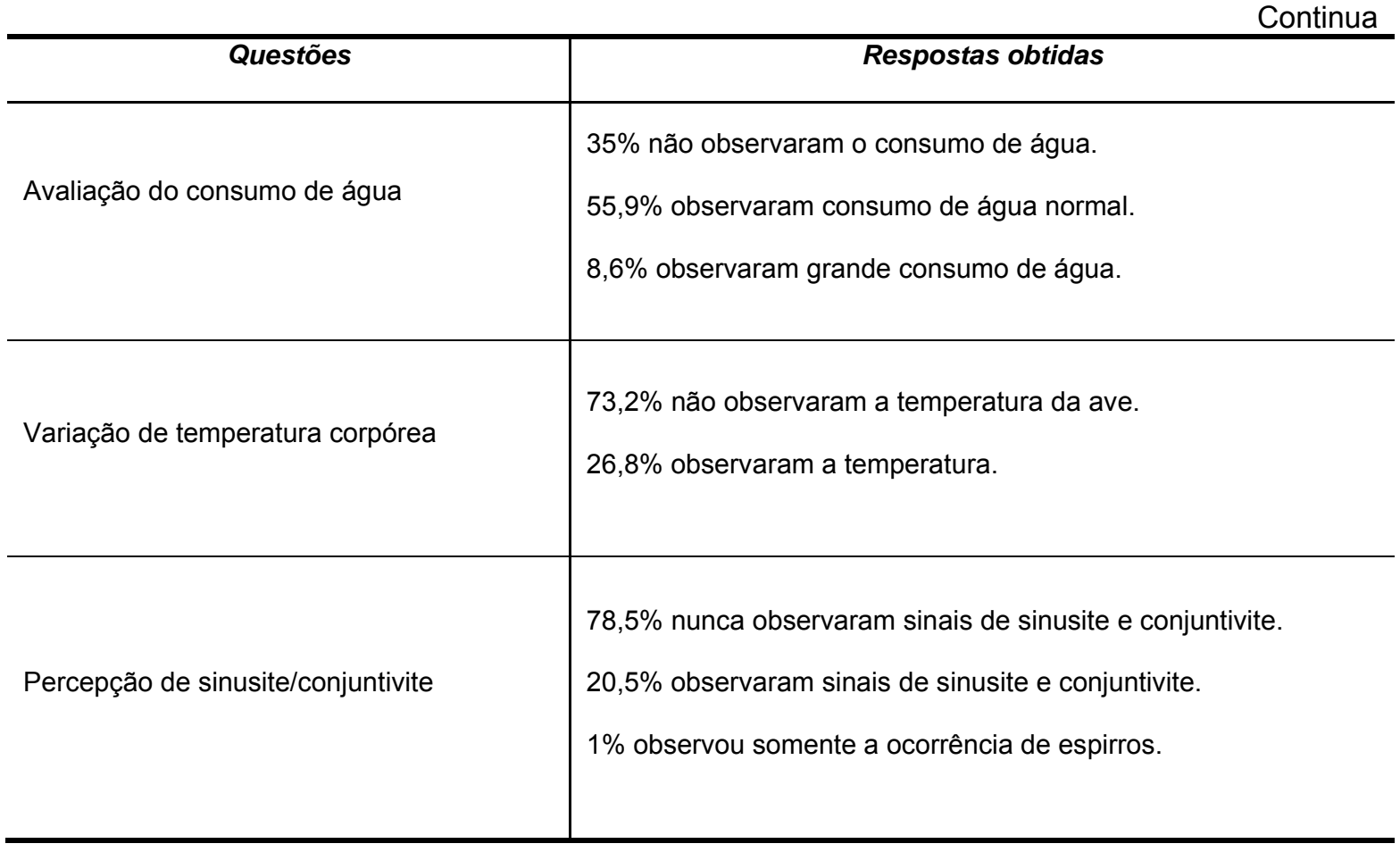




\begin{tabular}{c|l}
\hline \multicolumn{1}{c|}{ Questões } & \multicolumn{1}{c}{ Respostas obtidas } \\
\hline Percepção de problemas respiratórios & $\begin{array}{l}68,9 \% \text { nunca observaram problemas respiratórios. } \\
29,4 \% \text { notaram problemas respiratórios. } \\
1 \% \text { relatou a ocorrência de espirros de maneira constante. }\end{array}$ \\
\hline Percepção de problemas intestinais & $\begin{array}{l}1 \% \text { relatou somente que a ave parou de "cantar". } \\
65,7 \% \text { nunca observaram problemas intestinais. }\end{array}$ \\
& $34,3 \%$ observaram problemas intestinais. \\
\hline
\end{tabular}

Quadro 01 - Respostas referentes à saúde da ave, obtidas de 100 proprietários de aves atendidos na clínica veterinária Wildvet e avaliados durante a primeira consulta

O consumo de água não foi observado por $35,5 \%$ dos proprietários, e os demais $(64,5 \%)$ relataram estar conscientes da quantidade ingerida. Esta conduta observacional deve ser estimulada pelo veterinário quando orienta os seus clientes, pois em casos de ocorrência de diarreia ou disenteria, também ocorrem na poliúria por clamidiose aviária (RASO 2006).

$\mathrm{Na}$ observação da temperatura, os resultados para entrevistados que não avaliaram a temperatura corpórea de sua ave são ainda maiores que os valores obtidos no parâmetro anterior (73,2\%). Isto pode ser justificado pela dificuldade de avaliação deste quesito, uma vez que a mensuração da temperatura de uma ave exige um manejo e contato diretos, ficando, na maioria das vezes, uma avaliação pessoal e subjetiva.

A medição da temperatura corporal em mamíferos é de rotina do exame físico e uma valiosa ferramenta de diagnóstico. Porém, no caso das aves, na prática, medir a temperatura do corpo é de pouco valor diagnóstico (HARRISON; RITCHIE, 1994; SAMOUR; McKINNEY, 2000), isso porque termômetros tradicionais e digitais podem causar trauma na cloaca, além de exigirem alguns minutos para medir a 
temperatura, lembrando que o estresse da contenção física leva a mudanças na temperatura corporal das aves (HARRISON; RITCHIE, 1994; SAMOUR; McKINNEY, 2000).

Os proprietários deveriam ser orientados a observar mudanças de temperatura em suas aves, porque além de ajudar a encaminhar animais em estágios iniciais de doença, a clamidiose também é descrita como "febre dos papagaios" em referência a relatos de febre que ocorre em aves (NATIONAL ASSOCIATION OF STATE PUBLIC HEALTH VETERINARIANS, 2009). Esta informação pode ajudar no diagnóstico diferencial.

Sinusite e conjuntivite são sinais clássicos na clamidiose aviária (RASO, 2006), e apesar de $78,5 \%$ dos entrevistados relatarem que a ave nunca apresentou estes sinais de sinusite e conjuntivite, deve ser levado em consideração porque são sintomas fáceis de serem identificados por parte do proprietário e importantes nesse tipo de doença.

Doenças respiratórias em aves são passíveis de observação quando em estágios avançados (GODOY, 2001). No presente estudo ressalta-se que 31,1\% dos entrevistados perceberam alterações respiratórias e 1\% conseguiu associá-la com a "parada da vocalização". Carvalho (2004) citou que na clamidiose em psitacídeos os sinais respiratórios, espirros e dispneia estão associados à anorexia, diminuição de peso e depressão. Na realidade, em várias doenças esse conjunto de sintomas pode ocorrer. A vocalização pode ser suprimida em muitas doenças, bastando que o animal esteja debilitado (RUPLEY,1999), mas a descrição detalhada por parte do proprietário deve ser sempre estimulada.

Neste estudo, $65,7 \%$ dos entrevistados relataram que as aves nunca apresentaram problemas intestinais; $29,2 \%$ das aves tiveram problemas intestinais, mas que passaram com o tempo sem a necessidade de tratamento; $5,1 \%$ das aves apresentaram infecção intestinal e necessitaram de tratamento. A observação das fezes é importante e fácil de ser feita. No caso específico da clamidiose esta observação pode ajudar quando se relata a ocorrência de fezes esverdeadas (RUPLEY,1999). 
De acordo com a NATIONAL ASSOCIATION OF STATE PUBLIC HEALTH VETERINARIANS (2009), a clamidiose aviária apresenta manifestações clínicas inespecíficas, podendo ser observadas apatia, sonolência, anorexia, asas pendentes, desidratação, blefarite, conjuntivite e corrimento nasal. Ocorrem ainda alterações respiratórias (rinite, sinusite, dispneia), digestivas (diarreia amareloesverdeada), urinária (poliúria), reprodutivas (infertilidade, morte embrionária) e, nos estágios terminais, alterações neurológicas, como tremores, convulsões, opistótono e paralisia.

Os sinais mais comuns em psitacídeos são conjuntivite, diarreia, regurgitação, espirros, dispneia, anorexia, diminuição de peso e depressão (CARVALHO, 2004).

As questões relacionadas ao manejo das aves foram avaliadas (questões 06 a 10 do Apêndice A), e as respostas podem ser visualizadas no quadro 2.

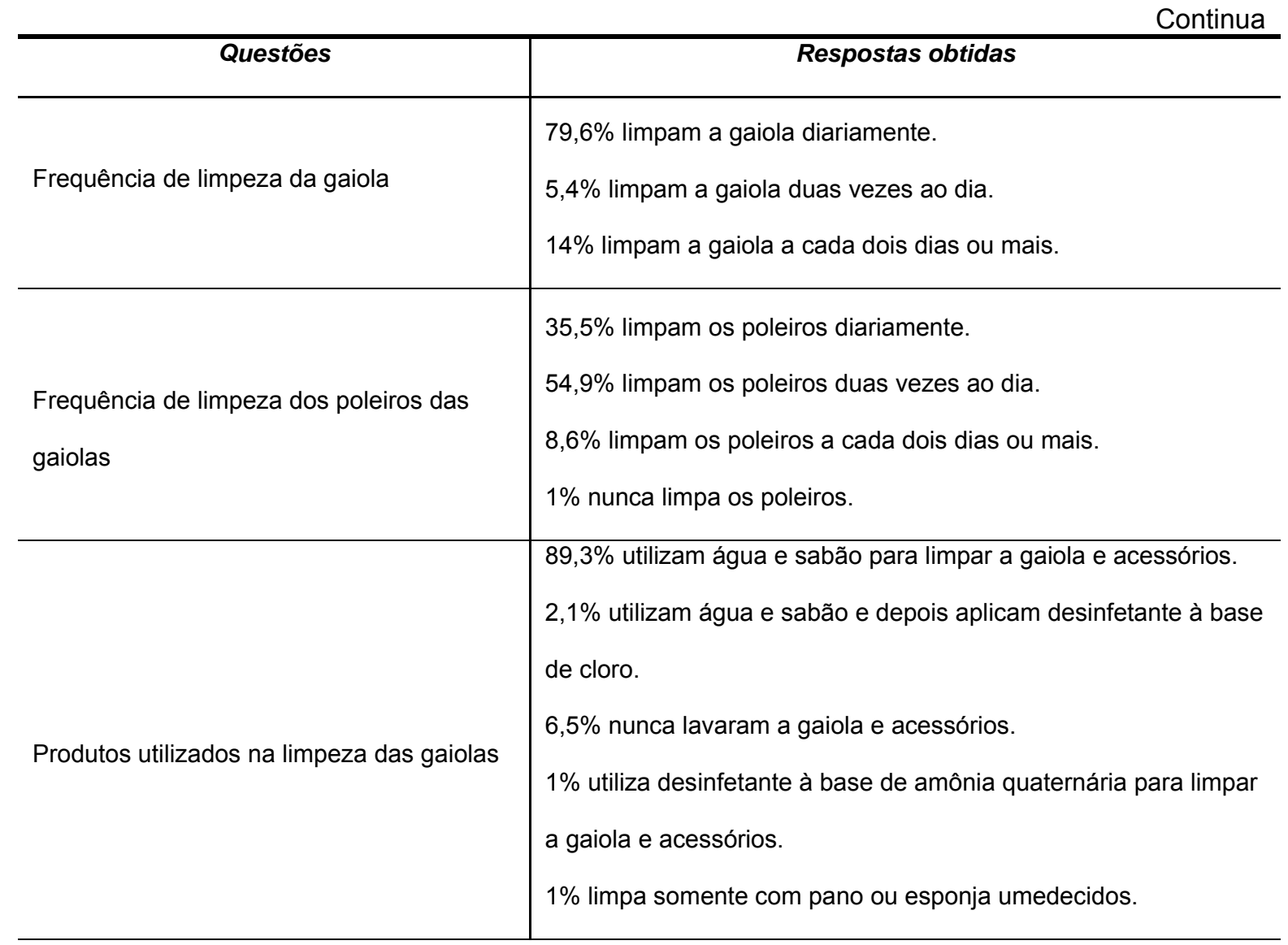


Conclusão

\begin{tabular}{l|l}
\hline \multicolumn{1}{c|}{ Questões } & \multicolumn{1}{c}{ Respostas obtidas } \\
\hline & $92,5 \%$ não utilizam nenhuma proteção. \\
Equipamentos de proteção individual & $7,5 \%$ quando utilizam proteção, usam somente luvas de \\
utilizados na limpeza & borracha. \\
\hline
\end{tabular}

Quadro 02 - Respostas referentes ao manejo e higiene da ave, obtidas de 100 proprietários de aves atendidos na Clínica Veterinária Wildvet e avaliados durante a primeira consulta.

A higienização de gaiolas é um procedimento necessário. Entretanto, na pesquisa realizada, $14 \%$ dos proprietários referiram não realizar limpeza diária da gaiola, $8,6 \%$ também não limpam os poleiros diariamente, $1 \%$ relatou nunca limpar os poleiros da gaiola e $6,5 \%$ nunca lavaram a gaiola e os acessórios.

As gaiolas e os poleiros constituem fômites importantes, podendo disseminar a clamidiose por longos períodos quando sujos com matéria orgânica contaminada, expondo outros animais e o homem; constituem uma fonte de infecção que, se negligenciada, inviabiliza o correto tratamento dos animais (CENTER FOR FOOD SECURITY AND PUBLIC HEALTH, 2005).

Raso (2007) afirma que a higiene precária pode ativar uma infecção latente, resultando na manifestação clínica da doença. A clamídia, quando protegida por matéria orgânica presente em fezes ou secreções, pode sobreviver por meses à dissecação ou ação direta do sol.

Dos proprietários entrevistados, 3,1\% se preocupam em utilizar desinfetantes. A C. psittaci é sensível ao calor e aos agentes que destroem os componentes lipídicos da parede celular. Neste caso, a orientação do veterinário deve ser fortalecida no sentido de recomendar fervura dos fômites e a utilização de produtos químicos, tais como formalina, peróxido de hidrogênio a $3 \%$, etanol a $70 \%$ e compostos de amônia quaternária (KHAN, 2006; RASO, 2007).

Dos entrevistados, 7,5\% relataram utilizar alguma proteção para higienizar as gaiolas e citaram exclusivamente o uso de luvas de borracha. No caso da clamidiose aviária o uso de máscaras durante a limpeza das gaiolas seria o mais 
adequado (TRÁVNICEK et al., 2002), pois a infecção em humanos ocorre normalmente com a inalação do organismo, o qual é aerossolizado das fezes secas ou das secreções respiratórias (MACFARLANE; MACRAE, 1983; YUNG; GRAYSON, 1988).

O uso de máscara não foi citado neste estudo, mas deve ser estimulado pelo veterinário, pois mesmo não tendo $100 \%$ de proteção efetiva, uma máscara ajuda a reduzir a carga infectante. As máscaras cirúrgicas comumente disponíveis no comércio não são consideradas equipamentos de proteção individual e por isso não são indicadas para o controle da clamidiose, como cita a NATIONAL ASSOCIATION OF STATE PUBLIC HEALTH VETERINARIANS, uma vez que a proteção facial filtrante básica (PFF1) permite a penetração de $20 \%$ de aerossóis (Cartilha de Proteção Respiratória contra Agentes Biológicos para Trabalhadores de Saúde - ANVISA). A NATIONAL ASSOCIATION OF STATE PUBLIC HEALTH VETERINARIANS (2009) recomenda o uso da PFF2 (equivalente a N95 da classificação Norte-Americana) ou superior, com penetração menor que $6 \%$ de aerossóis.

As questões relacionadas aos proprietários foram avaliadas (questões 11 a 13 do Apêndice A), e as respostas podem ser visualizadas no quadro 3.

\begin{tabular}{|c|c|}
\hline Questões & Respostas obtidas \\
\hline Mensuração do contato direto com as aves & $\begin{array}{l}53,8 \% \text { dos proprietários não têm contato direto com a ave (não a } \\
\text { retiram da gaiola). } \\
40,8 \% \text { mantêm contato direto com a ave. } \\
4,4 \% \text { relatam que dormem com a ave no quarto. } \\
1 \% \text { relata que a ave não fica presa (fica solta pela casa) }\end{array}$ \\
\hline $\begin{array}{l}\text { Conhecimento das zoonoses transmitidas } \\
\text { por aves }\end{array}$ & $\begin{array}{l}57 \% \text { não têm conhecimento sobre problemas de zoonoses em } \\
\text { relação às aves. } \\
38,7 \% \text { tinham conhecimento sobre problemas de zoonoses em } \\
\text { relação às aves, mas desconheciam quais eram. } \\
5,3 \% \text { tinham um bom conhecimento sobre problemas de } \\
\text { zoonoses em relação às aves. }\end{array}$ \\
\hline
\end{tabular}


Conclusão

\begin{tabular}{l|l}
\hline \multicolumn{1}{c|}{ Questões } & \multicolumn{1}{c}{ Respostas obtidas } \\
\hline & $\begin{array}{l}\text { 76,4\% dos proprietários nunca perderam ave por doença ou } \\
\text { morte súbita. } \\
\text { Ocorrência de óbitos de outras aves do }\end{array}$ \\
mesmo proprietário & $22,6 \%$ perderam ave por doença ou morte súbita, mas \\
& desconhecem o motivo. \\
& $1 \%$ perdeu ave por predação. \\
\hline
\end{tabular}

Quadro 03 - Respostas referentes à correlação e conhecimento de zoonoses aviárias, obtidas de 100 proprietários de aves atendidas na Clínica Wildvet e avaliados durante a primeira consulta

A informação de que $40,8 \%$ dos entrevistados tinham contato direto com seus animais é importante porque, mesmo que ocorra por curto período, se as aves forem portadoras de clamídia, há o risco de contraírem a doença. Stamm (1993) destaca que humanos podem contrair a doença mesmo com uma breve exposição às aves infectadas. Citando um caso humano de pneumonia grave, ocorrido em Minas Gerais, Moschioni et al (2001) afirmam que a maioria dos casos humanos de C. psittaci decorre do contato com aves.

Outro aspecto importante é que $4,4 \%$ dos entrevistados relataram dormir com a ave no quarto e $1 \%$ admitiu deixar a ave solta pela casa. A contaminação ambiental passa a ser um aspecto importante a ser trabalhado pelo veterinário, já que na clamidiose as aves infectadas, mesmo sem demonstrarem sinais clínicos da enfermidade, eliminam o micro-organismo de forma intermitente, disseminando a infecção para outras aves ou mesmo para os seres humanos (JERZY; STANISLAW, 2001; NATIONAL ASSOCIATION OF STATE PUBLIC HEALTH VETERINARIANS 2009). A NATIONAL ASSOCIATION OF STATE PUBLIC HEALTH VETERINARIANS (2009) ressalta a importância da orientação aos proprietários quanto à localização e higiene da gaiola e do contato intenso com o animal para evitar a transmissão desta zoonose.

As zoonoses provenientes de aves não são muito divulgadas, e no presente estudo, $57 \%$ dos proprietários admitiram não conhecer estas doenças; $38,7 \%$ 
tinham conhecimento da ocorrência de zoonoses provenientes de aves, mas afirmaram desconhecer quais são, o que reflete a ausência de orientação profissional na hora da aquisição de um exemplar. Ter o conhecimento da doença auxiliaria na prevenção. Em nota técnica sobre provável surto de psitacose no Rio Grande do Sul, ocorrido em 2007, a Secretaria de Saúde do Estado ressaltou a importância da disseminação da informação para técnicos e população (Anexo A). Em especial sobre a clamidiose aviária, a NATIONAL ASSOCIATION OF STATE PUBLIC HEALTH VETERINARIANS (2009) orienta quanto à conscientização de profissionais da área da saúde e da população para o controle da doença.

Dos entrevistados, os 5,3\% que disseram ter um bom conhecimento sobre as principais zoonoses transmitidas pelas aves, na hora de exemplificar citaram salmonela e/ou clamídia. Porém, existe um número relativamente grande de doenças aviárias, que são zoonoses potenciais, com particular significância para aqueles indivíduos que estão imunocomprometidos (HEMSWORTH; PFIZER, 2006).

Salmonelose, clamidiose, campilobacteriose e tuberculose são as zoonoses bacterianas aviárias mais frequentemente reportadas (ADESIYUN et al., 1998; FLAMER, 1999; HOOP, 2002). A criptosporidiose também é uma importante zoonose em se tratando de pessoas imunossuprimidas, embora o papel das aves na infecção em humanos ainda não esteja elucidado (TUMOVA et al., 2002).

Além dessas enfermidades, destaca-se ainda a gripe aviária, que desde 2004 vem causando a morte de várias pessoas na Ásia e na Europa, onde atualmente o vírus $\mathrm{H} 5 \mathrm{~N} 1$, cepa mais letal, tem sido isolado em diversos países (BEIGEL et al., 2006). Na Inglaterra, um caso de gripe aviária pelo H5N1 foi confirmado no final de 2005 num papagaio originário do Suriname (HAWKES, 2005).

$\mathrm{Na}$ avaliação feita pode-se observar que $22,6 \%$ dos proprietários relataram ter perdido uma ave por doença ou morte súbita, mas desconheciam a etiologia da doença e/ou não se interessaram em obter um diagnóstico preciso. A ausência do diagnóstico da causa mortis retrata uma situação comum que pode ser relacionada à falta de orientação por parte dos médicos veterinários. Esta observação é 
preocupante já que inúmeras zoonoses se manifestam no homem justamente quando suas aves estão doentes. (HEMSWORTH; PFIZER, 2006).

A análise das respostas obtidas nas 13 questões acima comentadas permite afirmar que os proprietários, mesmo sendo cuidadosos com seus animais, precisam de uma orientação mais contundente e direcionada à prevenção e manejo.

\subsection{AVALIAÇÃO DO PROTOCOLO DE TRATAMENTO ADOTADO}

Os resultados do protocolo experimental são apresentados na tabela 3 e 4 nas quais estão registrados os valores do controle de peso, os resultados dos exames bacteriológicos e da PCR para C. psittaci efetuados, antes e depois do tratamento.

Tabela 3 - Valores atribuídos às calopsitas naturalmente infectadas por C. psittaci e tratadas com doxiciclina segundo o número de identificação, momento de avaliação corpórea e dos resultados dos cultivos microbiológicos e PCR efetuados no início e final do tratamento - São Paulo, 2009.

\begin{tabular}{|c|c|c|c|c|c|c|c|c|c|c|c|c|c|c|}
\hline \multirow{2}{*}{ ID } & \multicolumn{10}{|c|}{$\begin{array}{l}\text { Controle de peso corpóreo }(\mathrm{g}) \\
\text { durante o período de tratamento }\end{array}$} & \multicolumn{2}{|c|}{ Cultura de fezes } & \multicolumn{2}{|c|}{$\begin{array}{l}\mathscr{N} \\
\mathbb{N} \\
\mathbb{N} \\
\mathbb{v} \\
0\end{array}$} \\
\hline & $\begin{array}{l}\stackrel{2}{\sim} \\
\stackrel{\sigma}{\sigma} \\
\stackrel{0}{0}\end{array}$ & $\begin{array}{l}\stackrel{2}{N} \\
\frac{\pi}{0}\end{array}$ & $\begin{array}{l}\stackrel{\mathscr{N}}{\sim} \\
\stackrel{\pi}{0}\end{array}$ & 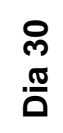 & $\begin{array}{l}\text { ○ } \\
\stackrel{\pi}{0}\end{array}$ & $\begin{array}{l}\stackrel{\leftrightarrow}{\mathscr{T}} \\
\frac{\pi}{0}\end{array}$ & $\begin{array}{l}\stackrel{\leftrightarrow}{\leftarrow} \\
\frac{\pi}{0}\end{array}$ & $\begin{array}{l}\text { 우 } \\
\frac{\pi}{0} \\
\frac{0}{0}\end{array}$ & 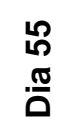 & 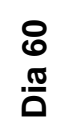 & & & & \\
\hline 1 & 58 & 55 & 50 & ÓBI & $2 / 02 /$ & & & & & & Escherichia coli & ÓBITO & + & $x$ \\
\hline 4 & 80 & 83 & 86 & 91 & 99 & 100 & 110 & 109 & 112 & 101 & $\begin{array}{l}\text { Escherichia coli, } \\
\text { Corynebacterium sp. }\end{array}$ & - & + & - \\
\hline 5 & 73 & 75 & 77 & 83 & 85 & 87 & 88 & 89 & 90 & 85 & Enterococcus sp. & - & - & - \\
\hline 6 & 78 & 79 & 83 & 86 & 99 & 108 & 112 & 113 & 113 & 103 & Escherichia coli & _ & _ & _- \\
\hline
\end{tabular}


Continua

\begin{tabular}{|c|c|c|c|c|c|c|c|c|c|c|c|c|c|c|}
\hline \multirow[b]{2}{*}{7} & \multicolumn{10}{|c|}{$\begin{array}{l}\text { Controle de peso corpóreo (g) } \\
\text { durante o período de tratamento }\end{array}$} & \multicolumn{2}{|c|}{ Cultura de fezes } & \multirow{2}{*}{$\begin{array}{l}\text { \& } \\
\mathbb{N} \\
\mathbb{N} \\
\frac{\mathbb{v}}{0} \\
\mathbb{Q}\end{array}$} & \multirow{2}{*}{ 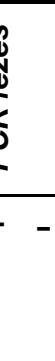 } \\
\hline & 76 & 76 & 77 & 82 & 89 & 92 & 100 & 97 & 97 & 85 & $\begin{array}{l}\text { Escherichia coli } \\
\text { Corynebacterium sp. } \\
\text { Enterococcus sp. }\end{array}$ & - & & \\
\hline 9 & 89 & 85 & 82 & 93 & 115 & 118 & 124 & 124 & 125 & 114 & Escherichia coli & - & + & - \\
\hline 10 & 79 & 82 & 88 & 96 & 99 & 99 & 98 & 99 & 102 & 97 & $\begin{array}{l}\text { Escherichia coli } \\
\text { Enterococcus sp. }\end{array}$ & - & + & - \\
\hline 11 & 88 & 88 & 89 & 88 & 88 & 90 & 91 & 90 & 88 & 90 & Escherichia coli & - & + & - \\
\hline 12 & 65 & 70 & 81 & 79 & 90 & 87 & 90 & 91 & 89 & 81 & Escherichia coli & - & + & - \\
\hline 13 & 67 & 71 & 79 & 80 & 90 & 95 & 95 & 93 & 93 & 84 & Escherichia coli & - & + & - \\
\hline 16 & 71 & 72 & 76 & 74 & 79 & 78 & 79 & 81 & 81 & 75 & Escherichia coli & - & + & - \\
\hline 19 & 88 & 86 & 85 & 91 & 107 & 107 & 105 & 101 & 101 & 97 & Escherichia coli & - & + & - \\
\hline 20 & 91 & 80 & 85 & 86 & 96 & 96 & 109 & 122 & 126 & 121 & Escherichia coli & $\begin{array}{l}\text { Streptococcus } \\
\text { sp. }\end{array}$ & + & - \\
\hline 21 & 71 & 72 & 75 & 78 & 84 & 84 & 82 & 81 & 82 & 78 & $\begin{array}{l}\text { Escherichia coli, } \\
\text { Enterococcus sp. }\end{array}$ & - & + & - \\
\hline 22 & 76 & 75 & 76 & 79 & 90 & 93 & 97 & 98 & 98 & 87 & Escherichia coli & - & + & - \\
\hline 23 & 80 & 80 & 78 & 80 & 83 & 86 & 96 & 100 & 95 & 92 & $\begin{array}{l}\text { Escherichia coli, } \\
\text { Enterococcus sp. }\end{array}$ & - & + & - \\
\hline 24 & 69 & 72 & 75 & 86 & 101 & 109 & 100 & 99 & 101 & 99 & $\begin{array}{l}\text { Escherichia coli } \\
\text { Enterococcus sp. }\end{array}$ & - & + & - \\
\hline 25 & 69 & 69 & 71 & 71 & 78 & 79 & 87 & 90 & 89 & 89 & Escherichia coli & - & + & - \\
\hline 26 & 67 & 71 & 79 & 83 & 87 & 86 & 86 & 86 & 88 & 76 & Escherichia coli & - & + & - \\
\hline
\end{tabular}


Conclusão

\begin{tabular}{|c|c|c|c|c|c|c|c|c|c|c|c|c|c|c|}
\hline \multirow[b]{2}{*}{27} & \multicolumn{10}{|c|}{$\begin{array}{l}\text { Controle de peso corpóreo (g) } \\
\text { durante o período de tratamento }\end{array}$} & \multicolumn{2}{|c|}{ Cultura de fezes } & \multirow{2}{*}{ 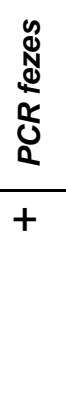 } & \multirow{2}{*}{ 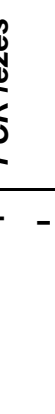 } \\
\hline & 77 & 82 & 87 & 87 & 92 & 95 & 95 & 95 & 101 & 90 & $\begin{array}{l}\text { Acinetobacter sp. } \\
\text { Enterococcus sp. } \\
\text { Staphylococcus sp. } \\
\text { Bacillus sp. }\end{array}$ & - & & \\
\hline 28 & 69 & 68 & 70 & 70 & 79 & 80 & 81 & 84 & 87 & 81 & Escherichia coli & - & + & _ \\
\hline 29 & 72 & 75 & 87 & 80 & 94 & 93 & 99 & 100 & 97 & 92 & $\begin{array}{l}\text { Escherichia coli, } \\
\text { Enterococcus sp. } \\
\text { Staphylococcus sp. }\end{array}$ & $\begin{array}{l}\text { Streptococcus } \\
\text { sp. }\end{array}$ & + & _ \\
\hline 30 & 75 & 77 & 82 & 85 & 90 & 92 & 93 & 91 & 94 & 89 & Escherichia coli & $\begin{array}{c}\text { Staphylococcus } \\
\text { sp. }\end{array}$ & + & _- \\
\hline 31 & 71 & 80 & 90 & 99 & 108 & 110 & 113 & 113 & 116 & 104 & Escherichia coli & $\begin{array}{l}\text { Escherichia coli } \\
\text { Streptococcus } \\
\text { sp. } \\
\text { Staphylococcus } \\
\text { sp. }\end{array}$ & + & - \\
\hline 32 & 81 & 80 & 83 & 80 & 86 & 90 & 97 & 91 & 96 & 89 & $\begin{array}{l}\text { Escherichia coli, } \\
\text { Staphylococcus sp. } \\
\text { Corynebacterium sp. }\end{array}$ & $\begin{array}{l}\text { Staphylococcus } \\
\text { sp. } \\
\text { Micrococcus } \\
\text { sp. }\end{array}$ & + & - \\
\hline 34 & 103 & 99 & 97 & 107 & 114 & 116 & 123 & 119 & 123 & 118 & $\begin{array}{l}\text { Escherichia coli } \\
\text { Enterococcus sp. } \\
\text { Micrococcus sp. }\end{array}$ & $\begin{array}{l}\text { Streptococcus } \\
\text { sp. }\end{array}$ & + & - \\
\hline
\end{tabular}

ID: identificação da ave

+ : positivo

-: negativo g: gramas

PCR: reação de polimerase em cadeia $\mathrm{x}$ : Óbito 
Tabela 4 - Valores atribuídos às calopsitas naturalmente infectadas por C. psittaci e não tratadas com doxiciclina segundo o número de identificação, momento de avaliação corpórea e dos resultados dos cultivos microbiológicos e PCR efetuados no início e final do procedimento. São Paulo, 2009.

\begin{tabular}{|c|c|c|c|c|c|c|c|c|c|c|c|c|c|c|}
\hline \multirow{2}{*}{ ID } & \multicolumn{10}{|c|}{ Controle de peso corpóreo (g) } & \multicolumn{2}{|c|}{ Cultura fezes } & \multirow{2}{*}{ 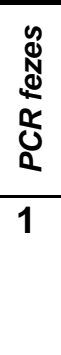 } & \multirow{2}{*}{$\begin{array}{l}2 \\
2\end{array}$} \\
\hline & $\begin{array}{l}\stackrel{2}{\Omega} \\
\stackrel{\sigma}{0}\end{array}$ & $\begin{array}{l}\text { กิ } \\
\frac{\pi}{0} \\
\end{array}$ & 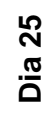 & $\begin{array}{l}\text { ळ్ల } \\
\stackrel{\pi}{0}\end{array}$ & 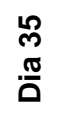 & $\begin{array}{l}\stackrel{9}{q} \\
\frac{\pi}{0}\end{array}$ & 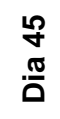 & $\begin{array}{l}\text { 오 } \\
\stackrel{\pi}{0} \\
\end{array}$ & 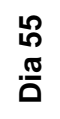 & $\begin{array}{l}8 \\
\frac{\pi}{0} \\
\frac{.0}{0}\end{array}$ & & & & \\
\hline 2 & 88 & 87 & 88 & 87 & 91 & 84 & 75 & 80 & 89 & 89 & $\begin{array}{l}\text { Escherichia } \\
\text { coli }\end{array}$ & $\begin{array}{c}\text { Streptococcus } \\
\text { sp. }\end{array}$ & + & + \\
\hline 3 & 80 & 85 & 98 & 93 & 100 & 91 & 85 & 90 & 91 & 86 & $\begin{array}{l}\text { Escherichia } \\
\text { coli }\end{array}$ & Escherichia coli & + & + \\
\hline 8 & 79 & 86 & 89 & 90 & 94 & 91 & 96 & 99 & 94 & 88 & $\begin{array}{l}\text { Escherichia } \\
\text { coli }\end{array}$ & $\begin{array}{c}\text { Staphylococcus } \\
\text { sp. }\end{array}$ & + & - \\
\hline 14 & 79 & 79 & 81 & 81 & 87 & 84 & 89 & 84 & 83 & 79 & $\begin{array}{l}\text { Escherichia } \\
\text { coli }\end{array}$ & $\begin{array}{c}\text { Streptococcus } \\
\text { sp. }\end{array}$ & + & - \\
\hline 15 & 72 & 77 & 79 & 82 & 93 & 90 & 90 & 88 & 87 & 82 & $\begin{array}{l}\text { Streptococcus } \\
\text { sp. }\end{array}$ & $\begin{array}{c}\text { Staphylococcus } \\
\text { sp. }\end{array}$ & + & + \\
\hline 17 & 88 & 85 & 81 & 87 & 95 & 96 & 94 & 95 & 91 & 83 & $\begin{array}{l}\text { Escherichia } \\
\text { coli }\end{array}$ & $\begin{array}{c}\text { Streptococcus } \\
\text { sp. }\end{array}$ & - & - \\
\hline
\end{tabular}

ID: identificação da ave

g: gramas

+ : positivo

PCR: reação de polimerase em cadeia

Os valores das avaliações individuais de peso das aves, registrados a cada cinco dias, apresentados nas tabelas 3 e 4 revelam que ao término do experimento (65 dias), a média de peso inicial e final das seis aves do grupo controle (Tabela 4) foi respectivamente de $81 \mathrm{~g}$ e $84,5 \mathrm{~g}$; já no grupo tratado (Tabela 3), no qual ocorreu um óbito na terceira semana, a média do peso foi de $77 \mathrm{~g}$ no início e 92,68g no final.

O ganho de peso do grupo tratado foi maior que o do grupo controle. A análise estatística constatou diferença significante entre as médias de peso inicial e final do grupo tratado $(p<0,0001)$, já o mesmo não ocorreu com as do grupo controle $(p=$ 
0,2009). Houve diferença estatística significante quando comparados grupo controle e grupo tratado no final do procedimento $(p=0,009)$. Tal resultado pode ser explicado pelo sucesso do tratamento com antibiótico adotado. De fato, Lesson et al. (1980) e Krinker e Jamorz (1996) constataram melhora no ganho de peso e conversão alimentar dos frangos de corte que receberam o antibiótico avoparcina como promotor de crescimento durante todo o período de criação.

As calopsitas, aparentemente saudáveis, estavam infectadas por C. psittaci, confirmado por PCR e também albergavam outras bactérias no intestino (Tabela 3 ). No grupo tratado $92,3 \%(24 / 26)$ dos animais apresentaram E. coli, em swabs cloacais efetuados antes do tratamento; o antibiótico utilizado (doxiciclina) reduziu os isolados de E. coli, o que pode justificar o ganho de peso observado. De fato a absorção dos alimentos pelos enterócitos ocorre nas vilosidades. O número desses enterócitos está associado ao tamanho dos vilos e seu aumento influencia a absorção dos alimentos (MACARI; MAIORKA, 2000). A presença de E. coli pode diminuir a altura de vilos, em termos absolutos (BORATTO et al., 2004).

Independentemente do fator antibiótico, todas as aves do grupo controle (Tabela 4) apresentaram média final de ganho de peso superior à média inicial, porém a diferença observada não foi significante $(p=0,2009)$. O desempenho do grupo controle pode ser consequência da criação das aves em instalações novas, com ótimas condições profiláticas, não constituindo, portanto, uma situação de desafio (BORATTO et al., 2004).

Antes do início do tratamento com antibiótico, os cultivos das amostras fecais (dia 07) das calopsitas apresentaram diversas bactérias: E. coli em 90,6\% (29/32), Enterococcus sp em 31,2\% (10/32), Corynebacterium sp e Staphylococcus sp em 9,3\% (3/32) e Bacillus sp, Micrococcus sp, Acinetobacter sp. e Streptococcus sp em $3,1 \%(1 / 32)$.

Durante o tratamento adotado houve o óbito de um animal, e assim o grupo tratado (Tabela 3) passou a ser de 25 animais. Aos 69 dias de experimento o cultivo das amostras fecais não apresentou crescimento bacteriológico em $76,0 \%$ das calopsitas (19/25); houve isolamento de Streptococcus sp em 16,0\% (4/25), Staphylococcus sp em 12,0\% (3/25) e Escherichia coli e Micrococcus sp em 4\% 
(1/25). No grupo controle (Tabela 4), constituído de seis animais não submetidos ao tratamento com antibiótico, também ocorreram mudanças nos resultados dos cultivos das amostras fecais, pois a presença de E. coli diminuiu de 83,3\% (5/6) para $16,6 \%(1 / 6)$ e houve aumento no número de isolados de Streptococcus sp, que passou de $16,6 \%$ (1/6) para $50 \%$ e do surgimento de $33,3 \%(2 / 6)$ de Staphylococcus sp.

Levando-se em conta o aspecto zoonótico de certas estirpes de E. coli e o respectivo potencial patogênico para mamíferos e aves (DELL'OMO et al., 1998; SCHREMMER et al., 1999; SCHMIDT et al., 2000; KOBAYASHI et al., 2002; KRAUSE et al., 2005), os resultados do presente estudo suscitam reflexões, pois a condição de patógeno primário ou oportunista é uma questão de grande controvérsia (SAIDENBERG; KNÖBL, 2006). Em aves de produção, a maior parte das ocorrências de doenças causadas por E. coli é secundária a fatores predisponentes ambientais e do hospedeiro (DHO-MOULIN; FAIRBROTHER, 1999). Inoculações experimentais de $E$. coli já comprovaram que a virulência desta bactéria está associada a outros micro-organismos e que os animais inoculados apenas com $E$. coli apresentam sintomas discretos, com menos lesões e menor persistência, quando comparados com inoculações associadas (GUIMARÃES, 1993).

Na Europa, Dorrestein et al. (1985) necropsiaram 466 psitacídeos e analisaram 80 amostras de fezes de outros psitacídeos, isolando E. coli em $41 \%$ das amostras de fezes e em 29\% das amostras de tecidos (fígado) colhidas durante as necrópsias. No presente estudo, após a realização do tratamento com doxiciclina, $83,3 \%(20 / 24)$ das calopsitas negativaram nas culturas de amostras fecais, o que indica forte impacto da antibioticoterapia prolongada sobre a microbiota bacteriana dos animais, em especial para E. coli, Corynebacterium sp, Enterococcus sp, Acinetobacter sp, Staphylococcus sp e Micrococcus sp. Nos casos em que a positividade da cultura permaneceu (6/24) houve a permanência da $E$. coli (1/6) e do Staphylococcus sp (1/6).

Informações concretas sobre o uso de antimicrobianos em aves de companhia são necessárias para que se analise o risco da ocorrência de clamidiose humana de origem aviária por estirpes de bactérias resistentes a antibióticos (VANROMPAY et 
al., 2007). A comprovação da presença de bactérias nas amostras fecais ao final do tratamento pode ser explicada pela diminuição da proteção por exclusão competitiva, ou seja, a capacidade de uma microbiota impedir a colonização intestinal por outros agentes (NURMI; RANTALA, 1973). Como ocorre com a administração de probióticos, compostos por micro-organismos da microbiota intestinal de aves normais podem determinar níveis de proteção às aves receptoras contra a colonização de alguns patógenos, principalmente Salmonella sp (ZIPRIN et al., 1993; NISBET et al., 1994; HOLLISTER et al., 1995; ANDREATTI; SILVA e CURI, 1997; ANDREATTI FILHO et al., 1999, 2000).

As diferenças de isolados, que ocorreram no grupo controle (Tabela 4), podem ser explicadas pela melhora da capacidade individual de combate aos agentes bacterianos, promovida pela melhoria das condições sanitárias do bioconfinamento (KOUTSUS; KLASING, 2008). Inicialmente 83,3\% (5/6) apresentaram E. coli em suas fezes, e no final, tendo recebido apenas placebo, a proporção caiu para $17,7 \%$ (1/6). Portanto, houve uma mudança na microbiota em ausência do tratamento com antibiótico.

A mudança na microbiota intestinal depende de fatores que influenciam o tipo e a intensidade da resposta imune. Entre estes estão incluídos fatores intrínsecos, como idade e sexo, e fatores extrínsecos tais como condições ambientais, interações sociais, exposição a agentes tóxicos e a qualidade da dieta (KOUTSUS; KLASING, 2008). No início do estudo, 93,5\% das aves (29/31) foram positivas para Chlamydophila psittaci, na PCR das amostras de swab cloacal (Tabela 1). Porém, foram adotados procedimentos de bioconfinamento coletivo para que, em conjunto com as características infecciosas da C. psittaci, fosse possível a positividade de todos os animais ao final do período de duas semanas de adaptação. Após o tratamento, todas as aves do grupo experimental não apresentaram a C. psittaci quando retestadas na PCR de amostras de swab cloacal. Os resultados obtidos no protocolo utilizado revelaram a eficácia do tratamento adotado e sugerem a ausência de resistência adquirida à doxiciclina pela C. psittaci. Achado semelhante foi relatado por Henning e Krauss (1986), que não detectaram resistência adquirida da C. psittaci contra a doxiciclina em estirpes de C. psittaci isoladas de aves e mamíferos. 
Apesar de os isolados de C. psittaci apresentarem alta sensibilidade à doxiciclina, no caso das aves os experimentos efetuados in vivo demonstraram que períodos de tratamento de 30 a 45 dias foram necessários para a cura completa (FLAMMER, 1989). Há de se considerar também que o sucesso do tratamento é dependente das respostas imunológicas do hospedeiro e do manejo do ambiente contaminado (FLAMMER, 1987). No presente estudo, o protocolo de tratamento foi elaborado contemplando boa alimentação e medidas de higiene ambiental associadas à utilização de EPIs.

Do ponto de vista epidemiológico, o protocolo de tratamento adotado no presente estudo foi eficaz, já que a presença da C. psittaci nas fezes das aves tratadas não foi detectada. Porém, a efetividade e eficiência do tratamento podem ficar comprometidas caso se avalie o perfil dos proprietários. De fato, o questionário aplicado na primeira etapa, revelou que parte dos proprietários entrevistados desconhecia as implicações da doença e do tratamento, deixando evidentes as irregularidades que ocorrem durante o bioconfinamento dos animais.

\subsection{RESULTADOS DOS EXAMES HISTOPATOLÓGICOS}

Os resultados dos exames histopatológicos efetuados com material de biópsia hepática, colhido no início e término do procedimento experimental estão nas tabelas 5 a 7 . 
Tabela 5 - Alterações histopatológicas circulatórias (congestão) encontradas nas biópsias hepáticas das calopsitas naturalmente infectadas com C. psittaci segundo a identificação da ave, grupo experimental e o momento da avaliação.- São Paulo - 2009

\begin{tabular}{|c|c|c|c|c|c|c|c|c|c|c|c|c|c|c|c|c|c|c|c|c|c|c|c|c|c|c|c|c|c|c|}
\hline \multicolumn{26}{|c|}{ TRATADO } & \multicolumn{5}{|c|}{ CONTROLE } \\
\hline ID & 1 & 4 & 5 & 6 & 7 & 9 & 10 & 11 & 13 & 16 & 19 & 20 & 11 & 22 & 23 & 24 & 25 & 26 & 27 & 28 & 2913 & 30 & 31 ; & 32 & 34 & $2:$ & 3 & \begin{tabular}{l|l|l}
8 & 14
\end{tabular} & 15 & 17 \\
\hline A & 1 & 1 & 3 & 1 & 1 & 2 & 2 & 1 & 1 & 1 & 0 & 1 & 1 & 0 & 1 & 1 & 2 & 1 & 2 & 1 & 1 & 0 & 1 & 2 & $1 \|$ & 1 & 2 & 1 & 1 & 1 \\
\hline CONGESTÄO - & & & & & & & & & & & & & & & & & & & & & & & & & & & & & & \\
\hline$D$ & - & 1 & 1 & 1 & 1 & 1 & 1 & 0 & 1 & 1 & 1 & 1 & 1 [ & 1 & 1 & 0 & 1 & 2 & 1 & 1 & 1 & 1 & 1 & 1 & $1 \|$ & 1 & 0 & 1 & 1 & 1 \\
\hline
\end{tabular}

ID - Identificação da ave, A - Anterior ao tratamento, D - Após o tratamento, * - Óbito

0 - Nenhuma alteração, 1 - Alteração leve; 2 - Alteração moderada e 3 - Alteração intensa

Para que a biópsia fosse considerada representativa, ela deveria conter pelo menos cinco tratos portais (CRAWFORD et al., 1998); já que todas as lesões fundamentais acometem preferencialmente a zona 3 (centro lobular), foram consideradas como representativas as biópsias que continham também pelo menos cinco veias centrolobulares.

Das biópsias iniciais efetuadas no grupo do tratamento, 11,5\% (3/26) não apresentaram sinais de congestão (classificação 0); 61,5\% (16/26) tiveram pequenas congestões (classificação 1); 19,2\% (5/26) congestões moderadas e uma amostra com lesões congestivas intensas (classificação 2 a 3). Na avaliação do grupo controle, 83,3\% (5/6) apresentavam congestão leve (classificação 1) e 16,6\% (1/6) congestão moderada (classificação 2).

Nos resultados das biópsias hepáticas efetuadas após o tratamento (Tabela 3), no grupo tratado, três animais que não apresentavam sinais de congestão no momento inicial passaram a apresentar congestão leve; das 16 aves que inicialmente apresentavam congestão leve, 13 mantiveram o resultado anterior, duas passaram a não apresentar sinais de congestão e uma evoluiu para congestão moderada. As cinco amostras, que inicialmente apresentavam congestão moderada e a amostra que apresentava congestão intensa passaram a apresentar congestão leve. No grupo controle observou-se que 16,6\% (1/6) passou de alteração moderada a ausência de congestão, enquanto que 83,3\% (5/6) não demonstraram alterações em relação à primeira biópsia. As alterações dos dois grupos estudados não mostraram diferenças estatisticamente significativas. 
Tabela 6 - Alterações histopatológicas degenerativas encontradas nas biópsias hepáticas das calopsitas naturalmente infectadas com C. psittaci segundo a identificação da ave, grupo experimental e o momento da avaliação - São Paulo - 2009.

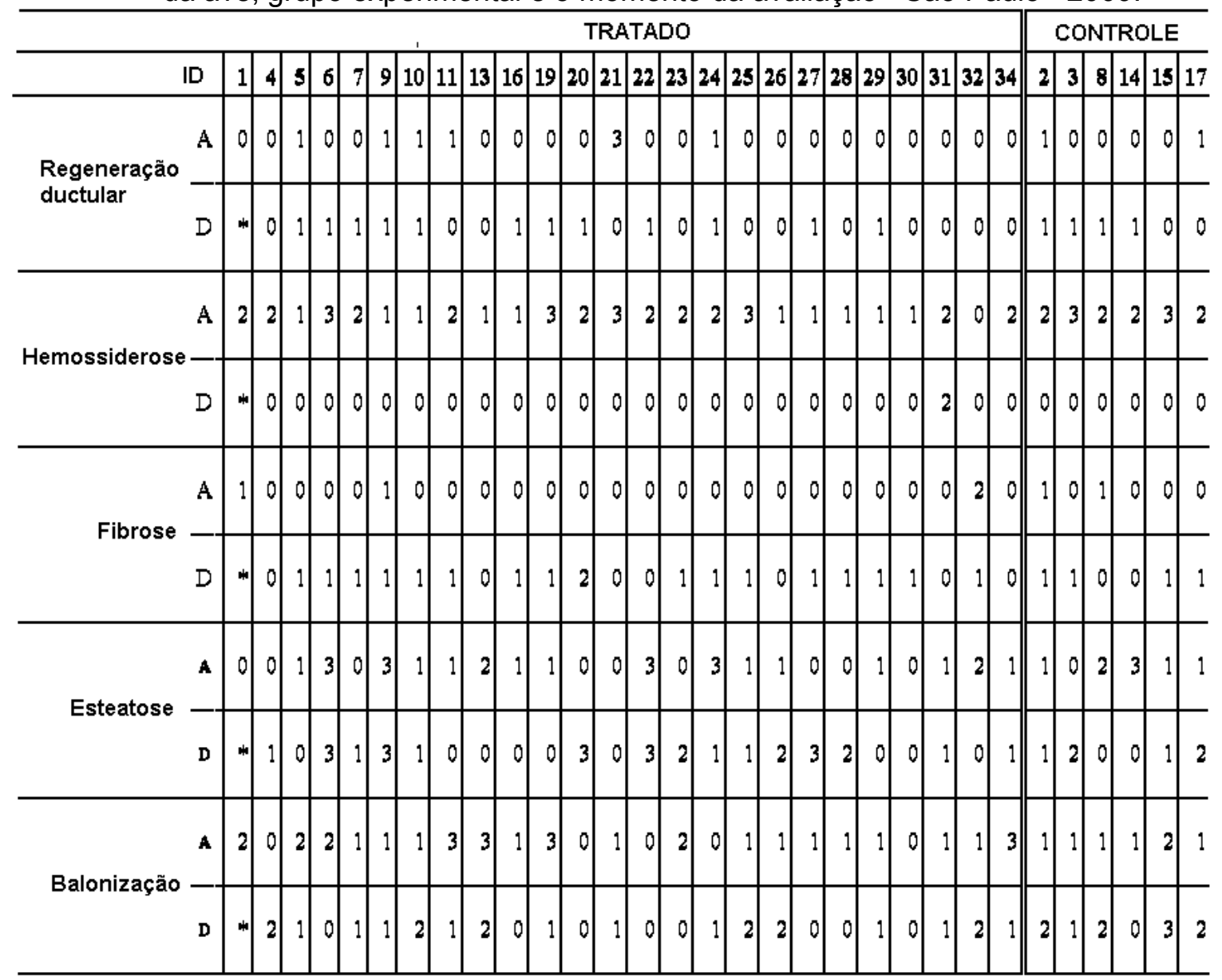

ID - Identificação da ave, A - Anterior ao tratamento, D - Após o tratamento, * - Óbito

0 - Nenhuma alteração, 1 - Alteração leve; 2 - Alteração moderada e 3 - Alteração intensa

$\mathrm{Na}$ tabela 6 as alterações de regeneração ductular, hemossiderose, fibrose, esteatose e balonização foram avaliadas em dois momentos. Estas alterações podem ser relevantes quando se avaliam o tratamento e infecção por $C$. psittaci.

Os hepatócitos replicam normalmente durante a embriogênese, crescimento, manutenção e substituição. No entanto, no caso de várias doenças, durante a hipertrofia adaptativa ou perda de massa funcionante do fígado, a replicação ou "regeneração" dos hepatócitos aumenta o tecido parenquimatoso. O fígado pode crescer ou encolher para atender às demandas metabólicas após a lesão ou em 
resposta a situações de excesso de massa funcional, como após amamentação ou perda de peso (STALKER; HAYES, 2007).

Três tipos de reação ductular são descritos na histopatologia hepática. O Tipo I corresponde ao alongamento dos dúctulos preexistentes pela proliferação das células, e seu forro é visto principalmente na obstrução aguda do ducto biliar. 0 Tipo II refere-se à metaplasia ductular de placas de células do fígado e foi observado predominantemente em condições crônicas colestáticas, como cirrose biliar primária. O Tipo III consiste de ativação e proliferação de células progenitoras hepáticas, aparecendo como periportal, estruturas ductulares no caso de (sub) necrose hepatocelular massiva e que representem uma alternativa (tentativa de) quando a capacidade de regeneração do parênquima hepatocelular é insuficiente, principalmente no caso de doenças crônicas do fígado (SANTOS, 1986).

Em relação à regeneração ductular, as comparações efetuadas dentro do grupo tratado e controle e nos dois momentos não demonstram diferenças estatisticamente significantes.

Não foi possível observar alterações de regeneração ductular que pudessem ser correlacionadas com a presença de clamídia ou alterações decorrentes do protocolo de tratamento.

$\mathrm{Na}$ avaliação da hemossiderose (Tabela 6), diferenças estatisticamente significativas observadas dentro do grupo tratado e controle $(p<0,001$ e $p=0,02$ respectivamente) demonstram uma diminuição da hemossiderose do início ao final do estudo. Não houve diferença estatística significante entre os grupos.

A diminuição da hemossiderose entre os dois momentos pode estar relacionada à alimentação oferecida durante o período de bioconfinamento do estudo. $O$ termo hemossiderose é usado quando o acúmulo progressivo de ferro em tecidos na forma de hemossiderina não causa alteração significativa na morfologia celular nem dano tecidual extenso que altere a função do órgão (LOWESTINE, 1986; LOWESTINE; MUNSON, 1999; RODENBUSCH et al., 2004; CARCIOFI; OLIVEIRA, 2007). A hemossiderose pode levar à morte de hepatócitos, gerando necrose celular isolada sem acometimento tecidual extenso ou significativo (CARCIOFI; OLIVEIRA, 2007). 
Aves silvestres mantidas em cativeiro com alimentos ricos em ferro, por exemplo ração de cães e gatos, e com a ingestão contínua de dietas com deficiência ou desequilíbrio de aminoácidos essenciais, vitaminas e minerais, apresentam deposição excessiva do mineral em órgãos parenquimatosos (WORELL, 1997; CRYSSEl et al., 2000; CUBAS, 2001; CUBAS, 2007; ANDREWS et al., 2005). Outras causas prováveis da ocorrência em aves incluem estresse, parasitismo intestinal, doenças (ALLEN; MONTALI, 1995; WORELL, 1997; CARCIOFI; OLIVEIRA, 2007).

A redução na síntese de hemácias também pode causar hemossiderose nas aves. Pacientes que estão com balanço calórico negativo ou apresentam doenças crônicas param de produzir hemácias ou as produzem em pequena quantidade, aumentando o reservatório de ferro nos tecidos. Como a destruição dos eritrócitos ocorre em um ritmo constante, o ferro reciclado dessas células acaba acumulandose no fígado, baço, rim e fagócitos. Este é um processo reversível e não está relacionado a processo mórbido (SCHMIDT et al., 2003).

A ocorrência de hemossiderose está relacionada diretamente com a sobrecarga de ferro, podendo ser classificada em genética, iatrogênica, por anemia hemolítica crônica, nutricional e experimental (SMITH,1997). De uma forma geral, a hemossiderose em animais resulta de taxa de destruição de hemácias maior que a normal; redução da utilização de ferro existente no organismo para a produção de hemoglobina; aumento das reservas de ferro por ingestão ou causa iatrogênica (SCHMIDT et al., 2003; RODENBUSCH, 2004).

A diminuição da hemossiderose com grande significância no grupo tratado pode estar relacionada ao tratamento da C. psittaci e da $E$. coli, uma vez que infecções que causam lesões no fígado podem levar a um depósito exagerado de ferro no órgão (LOWESTINE; MUNSON, 1999, JARAMILLO et al., 2004). Além disso, as alterações observadas na microbiota intestinal podem afetar a absorção de alguns nutrientes, como o ferro (De JONGE, 1973).

A análise estatística dos resultados da fibrose hepática (Tabela 6) intragrupo mostra uma grande diferença estatística no grupo tratado $(p<0,001)$, indicando um 
aumento da fibrose hepática nesse grupo. As demais análises estatísticas realizadas para esta lesão não demonstram diferenças significativas.

O aumento da ocorrência da fibrose no grupo tratado é possivelmente causado pela atividade metabólica do antibiótico utilizado (doxiciclina), que requer uma atividade constante do fígado, induzindo uma hipertrofia dos hepatócitos e consequente fibrose. A forte ação inibitória da doxiciclina pode estar relacionada à sua forte ligação com lipídios, favorecendo sua absorção intestinal em comparação a outras tetraciclinas (De JONGE, 1973).

A fibrose hepática é potencialmente reversível. Se o insulto subjacente é tratado eficazmente ou parado, o reparo tecidual é retardado a ponto de permitir a degradação do colágeno imaturo. O equilíbrio é derrubado em favor da fibrose progressiva quando o insulto continua a agir (STALKER; HAYES, 2007).

Um grande número de antibióticos que atuam na inibição da síntese proteica, atuando no ribossomo 70 s, interfere na atividade mitocondrial de síntese proteica em células eucariontes (De JONGE, 1973).

Experimentos realizados com cultura de hepatócitos de rato indicam que tetraciclinas em altas concentrações não inibem somente a síntese proteica em bactérias, e podem também atuar no ribossomo $80 S$ de células eucariontes, inibindo parcialmente a síntese proteica do citoplasma. A inibição da síntese proteica em fígado pode prejudicar gravemente a sua função e exerce efeitos sobre a morfologia ou função gastrointestinal (De JONGE, 1973).

No presente estudo não ocorreu diferença estatística significante nas avaliações dos resultados de esteatose entre e intragrupos, nos dois momentos. Porém, durante a realização da segunda biópsia notou-se um grande acúmulo de gordura cavitária nos animais tratados, indicando que o medicamento pode levar a uma possível alteração na metabolização de ácidos graxos e seu posterior acúmulo em adipócitos.

Trabalhos de Yesner e Kunkel (1951), Sborov e Sutherland (1951) e Lepper et al (1953) relatam que o uso da tetraciclina em humanos pode induzir esteatose hepática e observam que, mesmo quando utilizada em doses terapêuticas, a 
tetraciclina leva a um aumento de gordura no fígado que pode ser detectada em biópsia hepática.

A esteatose ou lipidose hepática descreve o acúmulo anormal de lipídios no citoplasma dos hepatócitos (THOMSON, 1983). Microscopicamente observa-se a presença de gotas grandes, claras e bem definidas de gordura no citoplasma dos hepatócitos. Pode haver deslocamento do núcleo do hepatócito pela gordura, fazendo com que o parênquima hepático tenha o aspecto de tecido adiposo (THOMSON, 1983).

No presente estudo, durante todo o período de bioconfinamento as aves receberam mistura de sementes. Segundo McLoughlin (1996), a maior causa de esteatose em psitacídeos é a alimentação rica em sementes oleaginosas, já que a lipólise excessiva causada pela metabolização de ácidos graxos livres de adipócitos é uma causa comum de transformação gordurosa hepática.

Outra variável analisada foi a balonização dos hepatócitos (Tabela 6). Não foi observada diferença significativa nos testes estatísticos aplicados entre e intragrupos nos dois momentos. Entretanto, a presença desta alteração pode estar relacionada com a congestão e esteatose anteriormente discutidas.

A balonização, alteração morfológica que denota dano celular, é consequência da disfunção de microtúbulos e da diminuição de secreção de proteínas, acompanhada de retenção de fluido dentro do hepatócito (BURT et al., 1999). O citoplasma dos hepatócitos baloniformes adquire aspecto finamente granular e eles se tornam arredondados, edemaciados. Geralmente estão presentes nas áreas com esteatose, na região perivenular (BRUNT, 2001; BRUNT, 2004). Esse tipo de degeneração é visto após vários insultos tóxicos e metabólicos, hipóxia e colestase (STALKER; HAYES, 2007).

As alterações inflamatórias estão apresentadas na Tabela 7. 
Tabela 7 - Alterações histopatológicas inflamatórias encontradas nas biópsias hepáticas das calopsitas naturalmente infectadas com C. psittaci segundo a identificação da ave, grupo experimental e o momento da avaliação. São Paulo - 2009

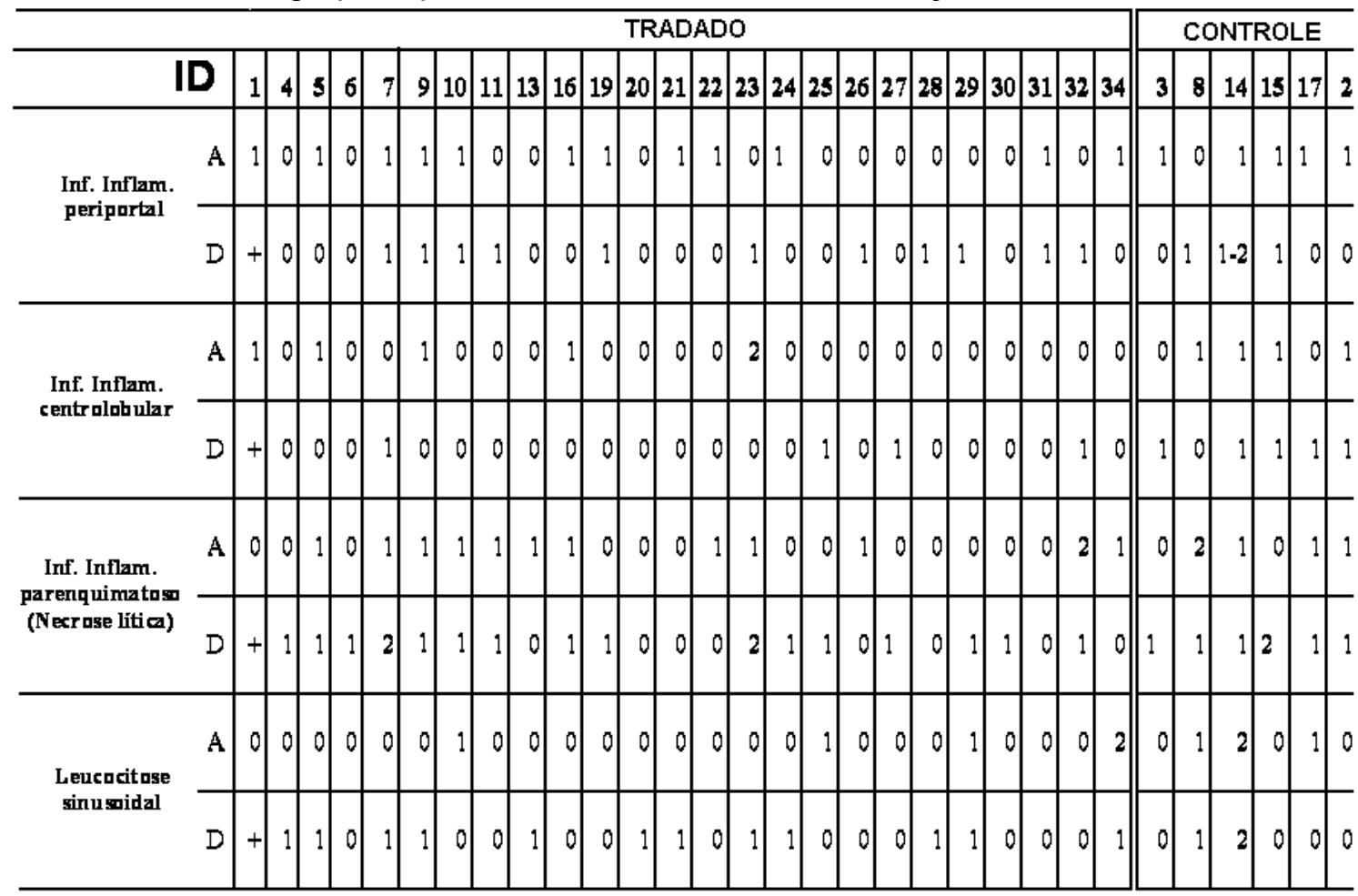

ID - Identificação da ave, A - Anterior ao tratamento, D - Após o tratamento, * - Óbito

0 - Nenhuma alteração, 1 - Alteração leve; 2 - Alteração moderada e 3 - Alteração intensa

No estudo realizado não houve diferença significativa nos infiltrados inflamatórios periportal e parenquimatoso (região mediozonal), zonas 1 e 2 respectivamente, nas análises estatísticas feitas intra e entre grupos nos dois momentos.

As mudanças significativas ( $p<0,01$ ) ocorreram na região centrolobular, com diminuição do infiltrado inflamatório quando comparamos os grupos entre si, após o tratamento. Este achado possivelmente está diretamente relacionado com a presença de C. psittaci promovendo injúrias aos hepatócitos. No grupo tratado pode-se sugerir que com a ação do antibiótico e eliminação do agente este processo inflamatório evoluiu para fibrose, que também pode ter contribuído com a diferença significativa de fibrose neste mesmo grupo. 
O processo inflamatório do fígado, com lesões focais ou difusas, é denominado hepatite. Pode ser causado por fungos, vírus, bactérias, parasitos ou quando há uma reação inflamatória intensa, independendo da causa. Microscopicamente, é caracterizado pela presença de leucócitos ao redor do ducto biliar e no interior dos espaços-porta (KELLY, 1990).

O processo inflamatório agudo acomete as zonas 2 e 3 , e quando atinge a zona 1 é sugestivo e caracteriza um processo inflamatório crônico, pois atinge até os hepatócitos metabolicamente favorecidos pelo aporte sanguíneo.

$\mathrm{Na}$ avaliação da leucocitose sinusoidal não houve diferença estatística significante nos testes aplicados entre e intragrupos estudados, nos dois momentos.

Aumento do número de leucócitos (leucocitose sinusoidal) é observado em sinusoides hepáticos em muitos casos de bacteremias aguda ou subaguda. Estas mudanças podem ser úteis para diagnóstico, mas eles não constituem uma prova de lesão hepática a menos que haja infiltração óbvia de granulócitos, monócitos ou linfócitos para o espaço perissinusoidal (STALKER; HAYES, 2007) o que não ocorreu neste presente estudo. 


\section{CONCLUSÕES}

Nas condições do presente estudo, pode-se concluir que:

- Os proprietários precisam de uma orientação mais contundente e direcionada à prevenção e manejo sanitário de suas aves.

- Há necessidade de orientação em relação ao uso de EPI, limpeza de acessórios e uso de desinfetantes.

- O protocolo de tratamento utilizando a doxiciclina foi eficaz eliminando a positividade das aves na PCR.

- As amostras obtidas por biopsia hepática foram representativas para os propósitos diagnósticos, não implicando em complicação e/ou mortalidade das aves após a cirurgia, indicando ser um procedimento eficiente e seguro mesmo para aves de pequeno porte.

- As avaliações observadas nas biopsias hepáticas não mostraram alterações significativas que pudessem contribuir com o diagnostico da clamidiose. 


\section{REFERENCIAS}

ADESIYUN, A. A.; CAESAR, K.; INDER, L. Prevalence of Salmonella and Campylobacter species in animals at Emperor Valley Zoo, Trindad. Journal Zoo Wildlife Medicine, v. 29, n. 2, p. 237-239, 1998

ALLEN, M. E.; MONTALI, R. J. Nutrition and disease in zoo animals. Verh Be. Erkrg Zootiere, vol. 37, p. 215-231, 1995.

ANDERSEN A.A Two new serovars of Chlamydia psittaci from North American birds. Journal of Veterinary Diagnostic Investigation, v. 9, n. 2, p. $159-164$, 1997

ANDERSEN A.A. Comparison of avian Chlamydia psittaci isolates by restriction endonuclease analysis and serovar-specific monoclonal antibodies. Journal of Clinical Microbiology. V 92, n. 2, p. $244-249,1991$ A

ANDERSEN A.A. Serotyping of Chlamydia psittaci isolates using serovar-specific monoclonal antibodies with the microimmunofluorescence test. Journal of Clinical Microbiology. V 29, n. 4, p. $707-711,1991$ B

ANDREATTI FILHO, R. L.; SILVA, E. N.; CURI, P.R. Ácidos orgânicos e microbiota cecal anaeróbia no controle da infecção experimental de frangos por Salmonella typhimurium e Salmonella enteritidis. Arquivo Brasileiro de Medicina Veterinaria e Zootecnia, v. 49, p. 661-672, 1997.

ANDREATTI FILHO, R.L.; MESTRINEL JÚNIOR, P.; SAMPAIO, H.M. et al. Efeito da vacina contra coccidiose sobre a colonização de Salmonella enteritidis em aves inoculadas com microbiota cecal anaeróbia. Arquivo Brasileiro de Medicina Veterinária e Zootecnia, v.51, p.311-316, 1999.

ANDREATTI FILHO, R.L.; SILVA, E.N.; RIBEIRO, A.R. et al. Use of anaerobic cecal microflora, lactose and acetic acid for the protection of broiler chicks against experimental infection with Salmonella Typhimurium and Salmonella Enteritidis. Brazilian Journal of Microbiology., v.31, p.107-112, 2000. 
ANDREWS, N.C. Disorders of iron metabolism. New England Journal of Medicine, Waltham, MA, v.341, p.1986-1995, 1999.

BANDURA, A. Health promotion by social cognitive means. Health, Education and Behavior, v. 31, n. 2, p. 143-164, 2004.

BEECKMAN, D. S.; VANROMPAY, D. C. Zoonotic Chlamydophila psittaci infections from a clinical perspective. Clinical Microbiology and Infection. $V$. 15, n. 1, p. 11-17, 2009. Review

BEER, J. Doenças infecciosas em animais domésticos. São Paulo: Roca, v. 1, p. $390-398,1988$ A

BEER, J. Doenças infecciosas em animais domésticos. São Paulo: Roca, v.1, p. 984-996, 1988 B

BEIGEL, J.H., FARRAR, J., HAN, A.M., HAYDEN, F.G., HYER, R., DE JONGE, M.D., LOCHINDARAT, S., NGUYEN, T.K., NGUYEN, T.H., TRAN, T.H., NICOLL, A., TOUCH, S., YUEN, K.Y.; Avian influenza A (H5N1) infection in humans. Writing Committee of the World Health Organization (WHO) Consultation on Human Influenza A/H5. N. Engl. J. Med., v.353, n.13, p.13741385, 2006.

BIONDI, M.; ZANNINO, L.G. Psychological stress, neuroimmunomodulation, and susceptibility to infectious diseases in animals and man: a review.

Psychotherapy Psychosomatics, v. 66, n. 1, p. 3-26, 1997.

BORATTO, A. J.; LOPES, D. C.; OLIVEIRA, R. F. M.; ALBINO, L. F. T.; SA, L. M.; OLIVEIRA, G. A.. Uso de antibiótico, de probiótico e de homeopatia, inoculados ou não com Esccherichia coli, para fraangos de corte criados em conforto.. Revista Brasileira de Zootecnia, v. 33, n. 6, p. 1477-1485, 2004.

BRUNT, E.M., JANNEY, C.G., DI BISCEGLIE, A.M., NEUSCHWANDER-TETRI, B.A., BACON, B.R. Nonalcoholic steatohepatitis: a proposal for grading and staging the histological lesions. Am J Gastroenterol; 94:2467-74. , 1999 
BRUNT, E.M., NEUSCHWANDER-TETRI, B.A., OLIVER, D. et al. Nonalcoholic steatohepatitis: histologic features and clinical correlations with 30 blinded biopsy specimens.. Hum Pathol; 35:1070 - 82, 2004.

BRUNT, E.M. Nonalcoholic steatohepatitis: definition and pathology. Semin Liver Dis; 21:3-16, 2001.

BUNCH, S.E., POLAK, D.M.; HORNBUCKLE, W.E.. A modified laparoscopic approach for liver biopsy in dogs. Journal of the American Veterinary Medical Association, n. 10, p. $1032-1035,1985$

CARCIOFI, A.C.; OLIVEIRA, L.D. Doenças Nutricionais. In: CUBAS, Z.S.; SILVA, J.C.R.; CATÃO-DIAS, J.L. Tratado de Animais Selvagens - Medicina Veterinária. São Paulo: Editora Roca, p.838-864, 2007.

CENTER FOR FOOD SECURITY AND PUBLIC HEALTH - CFSPH.

Chlamydiosis (Avian), Psittacosis, Ornithosis. 2005. Disponível em:

$<$ http://www.cfsph.iastate.edu/Factsheets/pdfs/chlamydiosis_avian.pdf > Acesso em: 15, Out. 2009.

CORREA, O. Doenças infecciosas dos animais domésticos. 2. ed. Rio de Janeiro: Freitas Bastos, 1975.

CRAWFORD, A.R.; LIN, X.Z., Crawford JM. The normal adult human liver biopsy: a quantitative reference standard. Hepatology. v. 28, n.2, p. $323-331$, 1998

CRISSEY, S.D.; WARD, A.M.; BLOCK, S.E.; MASLANKA, M.T. Hepatic iron accumulation over time in European starlings (Sturnus vulgaris) fed two levels of iron. Journal of Zoo and Wildlife Medicine, v.31, n.4, p.491-496, 2000.

CUBAS, Z.S. Medicine: Family Ramphastidae (Toucans). In: FOWLER, M.E.; CUBAS, Z.S. (Ed.). Biology, Medicine, and Surgery of South

American Wild Animals. Ames: lowa State University Press, p.188-199, 2001.

CUBAS, Z.S. Piciformes (tucanos, araçaris, pica-paus). In: CUBAS, Z.S.; SILVA, J.C.R.; CATÃO-DIAS, J.L. Tratado de Animais Selvagens - Medicina Veterinária. São Paulo: Editora Roca, p.210-221, 2007 
DAWELL, S.F.; PEELING, R.W.; BOMAN, J.; CARLONE, G.M.; FIELDS, B.S.; GUARNER, J.; HAMMERSCHLAG, M. R.; JACKSON,L.A.; KUO, C.C.; MAASS, M.; MESSMER, T.O.; TALKINGTON, D.F.; TUNDELLA, M.L.; ZAKI, S.R.; and the C. pneumoniae workshop participants. Standardizing Chlamydia pneumoniae Assays: Recommendations from the Centers for Disease Control and Prevention (USA) and the Laboratory Centre for Disease Control (Canada). Clinical Infectious Diseases v. 33, p. $492-503,2001$

De JONGE, H.R. Toxicity of tetracyclines in rat-small-intestinal epithelium and liver. Biochem. Pharmacol. V.22, p. 2659-2677,1973.

DEAN, D. D. F.; MCCARTHY, M.. Comparison of performance and costeffectiveness of direct fluorescent-antibody, ligase chain reaction and PCR assays forverification of chlamydial enzyme immunoassay results for populations with low to moderate prevalence of Chlamydia trachomatis infection. Journal of Clinical Microbiology, v. 36, p. 94 - 99, 1998

DELL'OMO, G.;MORABITO, S.; QUONDAM, R; AGRIMI, U.; CIUNCHINI, F.; MACRI, A; CAPRIOLI, A.. Feral pigeons as a source of verocytotoxin-producing Escherichia coli. The Veterinary record, v. 142, n. 12, p. $309-310,1998$

DESSUS-BABUS, S., BEBEAR, C. M., CHARRON, A., BEBEAR, C. \& DE BARBEYRAC, B. Sequencing of gyrase and topoisomerase IV quinoloneresistance-determining regions of Chlamydia trachomatis and characterization of quinolone-resistant mutants obtained in vitro. Antimicrobial Agents and Chemotherapy, v. 42, p. $2474-2481,1998$.

DHO-MOULIN, M.; FAIRBROTHER, J. M. Avian pathogenic Escherichia coli (APEC). Veterinary Research, v. 30, n. 2, p. 299-316, 1999.

DORRESTEIN, G. M.; BUITELAAR, M. N.; VAN DER HAGE, M. H., ZWART, P. Evaluation of a bacteriological and mycological examination of psittacine birds. Avian Diseases, v. 29, n. 4, p. 951-962, 1985.

DORRESTEIN, G.M. Chlamydiosis: a new approach in diagnosis and therapy. Proc. Assoc. Avian Vet. Seattle, p. 29-34, 1989. 
EUGSTER, A. K.. Chlamydiosis. In: STEELE, J. H. (Ed.). CRC handbook series in zoonoses, Boca Raton, FL: CRC Press, v. 2, p. 357 - 417, 1980.

EUROPEAN COMMISSION. Report of the Scientific Committee on Animal Health and Animal Welfare adopted 16 April 2002. Avian chlamydiosis as a zoonotic disease and risk reduction strategies. Disponível em:

<http://ec.europa.eu/food/fs/sc/scah/out73_en.pdf>. Acesso em: 28 Out. 2009.

EVERET, K. D.; ANDERSEN, A. A.; The ribosomal intergenic spacer and domain I of the 23S rRNA gene are phylogenetic markers for Chlamydia spp.

International Journal of Systematic Bacteriology, v. 47, n. 2, p.461 - 473, 1997.

EVERETT, K. D.; BUSH, R. M.; ANDERSEN, A. A.; Emended description of the order Chlamydiales, proposal of Parachlamydiaceae fam. nov. and Simkaniaceae fam. nov., each containing one monotypic genus, revised taxonomy of the family Chlamydiaceae, including a new genus and five new species, and standards for the identification of organisms. International Journal of Systematic Bacteriology, v. 49, pt. 2, p. 415-440, 1999.

FENGA, C.; CACCIOLA, A.; DI NOLA, C., CALIMERI, S.; LO, G. D.; PUGLIESE, M.; NIUTTA, P. P.; MARTINO, L. B.; Serologic investigation of the prevalence of Chlamydophila psittaci in occupationally-exposed subjects in eastern Sicily. Annals of Agricultural and Environmental Medicine, v. 14, p. 93-96, 2007

FERKET, P.R. Effect of diet gut microflora of poultry. In: GEORGIA NUTRITION CONFERENCE, 1., 1990, Atlanta. Proccedings.... Atlanta: Georgia University, p. 123-129, 1990.

FLAMER, K. Zoonosis Acquired from Birds. In: FOWLER, M.E.; MILLER, R. E. Zoo \& wild animal medicine: current therapy 4. Philadelphia: W.B. Saunders, p. 151-156, 1999.

FLAMMER, K.. Treatment of chlamydiosis in exotic birds in the United States. Journal of the American Veterinary Medical Association, v. 195, n. 11, p. $1537-1540,1989$. 
FLAMMER, K: Avian chlamydiosis - Observations on diagnostic techniques and use of oral doxycycline for treatment. In: International Conference On Zoological And Avian Medicine, 1., Oahu, Hawaii. Proceedings... Lake Worth, Fla.; Louisville, Ky.; The Associations, p. 149 - 158, 1987.

FLEMMING, J. S., FREITAS, R. J. S.. Avaliação do efeito de prebióticos (MOS), probióticos (Bacillus lecheniformes e Bacillus subtilis) e promotor de crescimento na alimentação de frangos de corte. Archives of Veterinary Science, v. 10, n. 2, p. 41-47, 2005.

FRIEND, M.; FRANSON, J;. CHRISTIAN, E.D. Field manual wildlife diseases: General Field Procedures and Diseases of Birds. Washington: USGS, p. 111114, 1999.

FURLAN, R. L.; MACARI, M.; LUQUETTI, B. C. Como avaliar os efeitos do uso de prebióticos, probióticos e flora de exclusão competitiva. In: SIMPÓSIO TÉCNICO DE INCUBAÇÃO, MATRIZES DE CORTE E NUTRIÇÃO, 5., 2004, Balneário Camboriú. Anais... Balneário Camboriú, p. 6-28, 2004.

GAEDE, W., RECKLING, K.F., DRESENKAMP, B., KENKLIES, S., SCHUBERT, E., NOACK, U., IRMSCHER, H.M., LUDWIG, C., HOTZEL, H., SACHSE, K. Chlamydophila psittaci infections in humans during an outbreak of psittacosis from poultry in Germany. Zoonoses Public Health, v. 55, p. 184-8, 2008.

GEENS, T; DEWITTE, A; BOON, N.; VANROMPAY, D.. Development of a Chlamydophila psittaci species-specific and genotype-specific real-time PCR. Veterinary Research, v. 36, n. 5/6, p. $787-797,2005$

GERLACH, H. Viral diseases. In: HARRISON, G. J.; HARRISON, L. R. Clinical avian medicine and surgery: including aviculture. Philadelphia: W. B. Saunders, p. 408-433, 1986.

GODOY, S. N. Patologia comparada de psitacídeos mantidos em cativeiro no Estado de São Paulo. 2001. 214 f. Dissertação (Mestrado) - Faculdade de Medicina Veterinária e Zootecnia, Universidade de São Paulo, São Paulo, 2001. 
GOSBELL, I. B.; ROSS, A. D.; TURNER, I. B.. Chlamydia psittaci infection and reinfection in a veterinarian. The Australian Veterinary Journal, v. 77, p. 511513, 1999.

GRIMES, J. E.; CLARK, F. D.; Pet psittacine birds: a continuing potential source of psittacosis for humans. Texas Medical, v. 82, n. 11, p. $46-47,1986$

GRIMES, J. E.; TULLY, T. N.; ARIZMENDI, F.; PHALEN, D. N.. Elementary body agglutination for rapidly demonstrat- ing chlamydial agglutinins in avian serum with em- phasis on testing cockatiels. Avian Diseases, v. 38, n. 4, p. $822-831$, 1994.

GUIMARÃES, I. G. Escherichia coli e suas interações em aves: patologias e métodos de controle. In: CONFERÊNCIA APINCO DE CIÊNCIA E TECNOLOGIA AVÍCOLAS, 1993, Campinas. Anais... Campinas: FACTA, p.43$71,1993$.

HAAG-WACKERNAGEL, D.. Feral pigeons (Columba livia) as potential source for human ornithosis. In:WORKSHOP FOR DIAGNOSIS AND PATHOGENESIS OF ANIMAL CHLAMYDIOSES v. 3, 2005, Siena, Proceedings... Italy: Bononia University Press, p. $15-16,2005$.

HARRISOS, G. J. RITCHEI, B. W.. Making distinctions in the physical examination. In: RITCHIE, B. W.;HARRISON, G.; HARRISON, L. (Eds) Avian Medicine: principles and application. lake worth, FL: Wingers, p. 148-169, 1994.

HAWKES, N. Quarantined parrot brought in first avian flu since. 1992.

Disponível em: <http://www.timesonline.com.uk>. Acesso em: 25 out. 2005.

HEMSWORTH, S.; PIZER, B. Pet ownership immnocompromised children: a review of the literature and survey of existing guidelines. European Journal of Oncology Nursing., v.10, n. 2, p. 117-127, 2006.

HEWINSON, R. G.; GRIFFITHS, P.C.; BEVAN, B.J.; KIRWAN, S. E. S.; FIELD, M.E.; WOODWARD, M. J.; DAWSON, M.. Detection of Chlamydia psittaci in avian clinical samples by polymerase chain reaction. Veterinary microbiology, v. 54, p. 155-166, 1997. 
HEWINSON, R. G.; RANKIN, S. E. S.; BEVAN, B. J.; FIELD, M.E.; WOODWARD, M. J.; Detection of Chlamydia psittaci from avian field samples using PCR. The Veterinary Record, v. 128, p. 129-130, 1991.

HINTON, JR. A; BUHR, R. J.; INGRAN, K.D.. Physical, chemical, and microbiological changes in the crop of broiler chickens subjected to incremental feed withdrawal. Poultry Science, v. 79, p. 212-218, 2000.

HOLLISTER, A.G., CORRIER, D.E., NISBET, D.J., BEIER, R.C., DELOACH, J.R.. Comparison of effects of chicken cecal microorganisms maintained in continuous culture and provision of dietary lactose on cecal colonization by Salmonella typhimurium in turkey poults and broiler chicks. Poult. Sci., v.73, p.640-647, 1994.

HOOP, R. Mycobacterium tuberculosis infection in a canary (Serinus canaria L.) and a blue-fronted amazon parrot (Amazona aestiva). Avian Disease., v. 46, n. 2, p. 502-504, 2002.

HUGHES, C.; MAHARG, P.; ROSARIO, P.; HERREL, M.; BRATT, D.; SALGADO, J.; HOWARD, D. Possible nosocomial transmission of psittacosis. Infection Control and Hospital Epidemiology, v.18, p. 165-168, 1997.

ITO, I.; ISHIDA, T.; MISHIMA, M.; OSAWA, M.; ARITA, M., HASHIMOTO, T.; KISHIMOTO, T..Familial cases of psittacosis: possible person-to-person transmission. Internal Medicine, v. 41, p. $580-583,2002$.

JARAMILLO, E.; SCHLATTER, R.; CONTRERAS, H.; DUARTE, C.; QUIROZ, E.; PALMA, H.; ULLOA, J.; PAREDES, E.; VALENZUELA, G. Estudio sobre origen de mortalidades y disminución poblacional de aves acuáticas en el santuario de La naturaleza Carlos Andwanter en la Provincia de Valdivia. Universidad Austral de Chile .15 Diciembre, 2004. Disponível em: http://www.emol.com/noticias/documentos/pdfs/cisnes_mortalidad_final.pdf. Acesso em: 15 out. 2009.

JERZY, R.; STANISLAW, T. Birds as a potential source of human infection by Chlamydiae. Scand. Journal of infectious diseases, v. 57 , n. 7, p. 459-463, 2001. 
JONES, R. B.,VANDERPOL, B.; MARTIN, D. H.; SHEPARD, M. K.. 1990. Partial characterization of Chlamydia trachomatis isolates resistant to multiple antibiotics. Journal of infectious diseases, v. 162, p. 1309-1315, 1990.

KALETA, E. F.; TADAY, E.M..Avian host range of Chlamydophila spp. based on isolation, antigen detection and serology. Avian Pathol. v. 32, n. 5, p. $435-461$, 2003.

KELLY, W. R. El hígado y el sistema biliar. In: JUBB, K. V. F.; KENNEDY, P. C.; PALMER, N. Patologia de los animales domésticos. Montevideo:

Editorial Agropecuaria Hemisferio Sur, 1990. T. 2, p. 277-360.

KHAN, C. M. (Ed.). The merck veterinary manual. $9^{\text {th }}$ ed. Whitehouse Station: Merck \& Co., 2006.

KLEINER, D. E.;BRUNT, E. M.; VANNATTA, M.; BEHLING, C., CONTOS, M.J.; CUMMINGS, O. W.; FERREL, L. D.; LIU, Y. C.; TORBENSON, M. S.; UNALPARIDA, A.; YEH, M.; MCCULLOUGH, A. J.; SANYAL, A. J.; Nonalcoholic Steatohepatitis Clinical Research Network. Design and validation of a histological scoring system for nonalcoholic fatty liver disease. Hepatology, v. 41, n. 6, p. $1313-1321,2005$.

KOBAYASHI, H.; POHJANVIRTA, T.; PELKONEN, S. prevalence and characteristics of intimin- and shiga toxin-producing Escherichia coli from gulls, pigeons and broilers in Finland. Journal of Veterinary Medical Science, v. 64, n. 11, p. 1071-1073, 2002.

KOONIN, E.V., MAKAROVA, K.S., ARAVIND, L. Horizontal gene transfer in prokaryotes: quantification and classification. Annu Rev Microbiol, v. 55, p. 70942. 2001.

KOUTSUS, E.; KLASING, K. C. Factors modulating the avian immune system. In: DAVISON, F.; KASPERS, B.; SCHAT, K. A. Avian Immunology. Londres, Reino Unido: Academic Press, p. 323-338, 2008. 
KRAUSE, G.; ZIMMERMANN, S.; BEUTIN, L. Investigation of domestic animals and pets as a reservoir for intimin (eae) gene positive Escherichia coli types. Veterinary Microbiology, v. 106, n. 1-2, p. 87-95, 2005.

KRINKE, A.L., JAMROZ, D. Effects of feed antibiotic avoparcine on organ morphology in broiler chickens. Poult. Sci., v. 75, p. 705-710, 1996.

LABRO, M.T. Intracellular bioactivity of macrolides. Clin Microbiol Infect. Mar;1 Suppl 1, p. S24-S30, 1996.

LAROUCAU, K., MAHE, A. M., BOUILLIN, C., DEVILLE, M., GANDOUIN, C., TOUATI, F., GUILLOT, J. \& BOULOUIS, H. J. Health status of free-living pigeons in Paris. In Proceedings of the 3rd Workshop for Diagnosis and Pathogenesis of Animal Chlamydiosis, p. 17-18. Edited by R. Cevenini \& V. Sambri. Siena, Italy: Bononia University Press. 2005.

LEFEVRE, J. C., LEPARGNEUR J. P. Comparative in vitro susceptibility of a tetracycline-resistant Chlamydia trachomatis strain isolated in Toulouse (France). Sex. Transm. Dis. v. 25, p. 350-352. 1998.

LEITE, F. T., Metodologia Científica de Pesquisa: monografias, dissertações, teses e livros. Idéias \& Letras, Aparecida, SP, 2008.

LENART, J., ANDERSEN, A.A., ROCKEY, D.D. Growth and development of tetracycline-resistant Chlamydia suis. Antimicrobial Agents and Chemotherapy, v. 45(8), p. 2198-203, 2001.

LEPPER, M. H., ZIMMERMAN, H. J., CARROL. G., CALDWELL, E. R., SPIES H. W., WOLFE, C. K., DOWLING, H. F. Effect of Large Doses of Aureomycin, Terramycin and Chloramphenicol on Livers of Mice and Dogs. Arch. Int. Med., v. 88, p. 284, 1951.

LESSON, S., SUMMERS, J.D., FERGUNSON, A.E. Efficacy of avoparcin as a growth promoter for broiler chickens. Can. J. Anim. Sci., v. 60, p. 275-279, 1980. 
LIMA, V.Y., RASO, T. F., ARAÚJO JR, J.P. Chlamydophila psittaci em pombos (Columba livia) capturados no Parque Zoológico Municipal de Bauru/SP. In: XXVII Congresso da Sociedade de Zoológicos do Brasil, 2003, Bauru. Anais..., 2003.

LOWENSTINE, L. J. Nutritional disorders of birds. In: FOWLER, M.E. (ed.). Zoo and Wild Animal Medicine. Philadelphia: W.B. Saunders, , p.201-212, 1986.

LOWESTINE, L.J.; MUNSON, L. Iron overload in the animal kingdom. In: FOWLER,M.E.; MILLER, R.E. (Ed.). Zoo \& Wild Animal Medicine:

Current Therapy 4. Philadelphia: W.B. Saunders Company, p.260-268, 1999.

MACARI, M.; MAIORKA, A. Função gastrointestinal e seu impacto no rendimento avícola. In: CONFERÊNCIA APINCO`2000 DE CIÊNCIA E TECNOLOGIA AVÍCOLAS, 2000, Campinas. Anais... Campinas : FACTA, v. 2, p. $161-174,2000$.

MACARI, M. ; FURLAN, R. L. Probióticos. In: CONFERÊNCIA APINCO DE CIÊNCIA E TECNOLOGIA AVÍCOLAS, 1., 2005, Campinas. Anais...

Campinas: FACTA, p. 53-71, 2005.

MACFARLANE, J.T., MACRAE, A.D. Psittacosis. Br Med Bull. V. 39(2), p. 1637, 1983.

MAHONY, J.B., CHONG, S., COOMBES, B.K., SMIEJA, M., PETRICH, A. Analytical sensitivity, reproducibility of results, and clinical performance of five PCR assays for detecting Chlamydia pneumoniae in peripheral blood mononuclear cells. Journal of Clinical Microbiology, v. 38, p. 2622-2627, 2000.

MARTIN, R.A. Congenital portosystemic shunts in the dog and cat. Vet Clin North Am Small Anim Pract. v. 23(3), p. 609-23, 1993.

MCELNEA, C.L., CROSS, G.M. Methods of detection of Chlamydia psittaci in domesticated and wild birds. Australian Veterinary Journal, v. 77(8), p. 516$521,1999$. 
MCLOUGHLIN, A. P. Polydipsia and polyuria. In: Manual of psittacine birds. Cheltenham: BSAVA, p. 158-170, 1996.

MCORIST, S. Obligate intracellular bacteria and antibiotic resistance. Trends Microbiol, v.8(11), p. 483-6, 2000.

MENTEN, J. F. M.; PEDROSO, A. A. Fatores que interferem na eficácia de probióticos. In: CONFERÊNCIA APINCO 2005 DE CIÊNCIA E TECNOLOGIA AVÍCOLAS, 2000, Campinas. Anais... Campinas: FACTA, v. 1, p. 41-52, 2005.

MESSMER, T.O., SKELTON, S.K., MORONEY, J.F., DAUGHARTY, H., FIELDS, B.S. (). Application of a nested, multiplex PCR to psittacosis outbreaks. Journal of Clinical Microbiology, v. 35(8), p. 2043-2046, 1997.

MITEVSKI, D., PENDOVSKI, L., NALETOSKI, I. I. V. Surveillance for the presence of Chlamydophila psittaci in pigeons and doves from several towns in Macedonia. In: Proceedings of the 3rd Workshop for Diagnosis and Pathogenesis of Animal Chlamydiosis. Edited by R. Cevenini \& V. Sambri. Siena, Italy: Bononia University Press, p. 141-145, 2005.

MOHAN, R. Epidemiologic and laboratory observations of Chlamydia psittaci infection in pet birds. J Am Vet Med Assoc, v. 184, n. 11, p. 13721374, 1984.

MOORE, F.M., MCMILAN, M.C., MARGERET, L. , PETRAK, M.L., Comparison of culture peroxidase - anti peroxidase reaction and serum latex agglutination methods for diagnosis of chlamydiosis in pet birds. J. Vet. Med. Assoc., v. 199, p. 71-73, 1991.

MORONEY, J.F., GUEVARA, R., IVERSON, C., CHEN, F.M., SKELTON, S.K., MESSMER, T.O., PLIKAYTIS, B., WILLIAMS, P.O., BLAKE, P., BUTLER, J.C.,. Detection of chlamydiosis in a shipment of pet birds, leading to recognition of an outbreak of clinically mild psittacosis in humans. Clin. Infect. Dis., v. 26, p. 1425-1429, 1998.

MORRISSEY, I., SALMAN, H., BAKKER, S., FARRELL, D., BEBEAR, C. M., RIDGWAY, G., Serial passage of Chlamydia spp. in sub-inhibitory 
fluoroquinolone concentrations. Journal of Antimicrobial Chemotherapy., v. 49, p. $757-761,2002$.

MOSCHIONI, C., FARIA, H. P., REIS, M. A. S., SILVA, E. U., Pneumonia grave por "Chlamydia psittaci". J. Pneumologia., vol.27, n.4, 2001.

NATIONAL ASSOCIATION OF STATE PUBLIC HEALTH VETERINARIANS NASPH. Compendium of measures to control Chlamydophila psittaci infection among humans (psittacosis) and pet birds (avian chlamydiosis) 2009. Disponível em: <http://www.nasphv.org/Documents/Psittacosis.pdf.> Acesso em: : 15, Out, 2009.

NESS, R. D. Integrative therapies. In: HARRISON, G. J.; LIGHTFOOT, T. L. Clinical avian medicine. Florida, EUA: Spix., p. 343-364, 2006.

NEWHALL, W.J., JOHNSON, R.E., DELISLE, S., FINE, D. Head-to-head evaluation of five chlamydia tests relative to a quality-assured culture standard. Journal of Clinical Microbiology., v. 37, p. 681-685, 1999.

NISBET, D.J.; RICKE, S.C.; SCANLAN, C.M., BEIER, R.C. Inoculation of broiler chicks with a continuous-flow derived bacterial culture facilitates early cecal bacterial colonization and increases resistance to Salmonella typhimurium. J. Food Protect. , v.57, p.12-15, 1994.

NURMI, F., RANTALA. M. New aspects of Salmonella infection in broiler production. Nature., v. 241, p. 210-211, 1973.

OLSEN, B., PERSSON, K., BROHOLM, K.A. PCR detection of Chlamydia psittaci in faecal samples from passerine birds in Sweden. Epidemiology and Infection., v. 121(2), p. 481- 484, 1998.

ORDEM INTERNACIONAL DE EPIZOTIAS. Manual of diagnostic tests and vaccines for terrestrial animals 2004. Disponível em: < http://www.oie.int/esp/normes/mmanual/A_00105.htm>. Acesso em: 15 Out. 2009. 
PAGE, L.A. Interspecies transfer of psittacosis-LGV-trachoma agents:

pathogenicity of two avian and two mammalian strains for eight species of birds and mammals. Am J Vet Res., v. 27(117), p. 397-407, 1966.

PROPHET, E.B., MILLS, B., ARRINGTON, J.B., SOBIN, L.H. Laboratory methods in histotechnology. Washington: Armed Forces Institute of Pathology, 1992. 279p.

RASO, T.F., CARRASCO, A.O., SILVA, J.C., MARVULO, M.F., PINTO, A.A. Seroprevalence of Antibodies to Chlamydophila psittaci in Zoo Workers in Brazil. Zoonoses Public Health., v.17, 2009.

RASO, T. F. ; TEIXEIRA, R.H.F. ; NUNES, A.L.V. ; ARAÚJO JR, J.P. ; PINTO, A.A. . Detecção de Chlamydophila psittaci em Araras-azuis (Anadorynchus hyacynthinus) apreendidas no Estado de São Paulo.. In: X Congresso Brasileiro de Ornitologia, 2002, Fortaleza. Anais..., 2002.

RASO, T. F. ; TEIXEIRA, R.H.F. ; VAZ, F.J. ; NOGALI, O. ; PINTO, A.A. . Pesquisa de Chlamydophila psittaci em ramphastídeos da Fundação Parque Zoológico de São Paulo. In: IX Congresso e XIV Encontro da ABRAVAS, 2005, São José do Rio Preto. Anais... p. 44, 2005.

RASO, T. F. Detecção de infecção por Chlamydia psittaci em papagaios do genero Amazona mantidos em cativeiro. M.Sc. Thesis, Univ. of State of São Paulo, São Paulo, Brazil. 1999.

RASO, T. F. Chlamydophila psittaci in free-living blue-fronted amazon parrots (Amazona aestiva) and hyacinth macaws (Anodorhynchus hyacinthinus) in the Pantanal of Mato Grosso do Sul, Brazil. Veterinary Microbiology, v. 117, Issues 2-4, 31 October 2006, Pages 235-241.

RASO, T.F. Clamidiose. In: CUBAS, Z. S.; SILVA, J. C. R.; CATÃO DIAS, J. L. Tratado de animais selvagens. São Paulo: Roca, Cap. 47, p. 760-767, 2007.

RIDGWAY, G.L. Treatment of chlamydial genital infection. J Antimicrob Chemother. Sep;40(3):311-4, 1997. 
RODENBUSCH, C.R. Hemossiderose e hemocromatose em aves silvestres - Revisão. Clínica Veterinária, v.9, n.53, p 44-50, nov./dez. 2004.

ROSA, M. V. F. P. C.; ARNOLDI, M.A.G.C. A entrevista na pesquisa qualitativa: mecanismo para validação dos resultados. Belo Horizonte: Autêntica, 2008 $107 \mathrm{p}$.

Sachse K, Laroucau K, Vorimore F, Magnino S, Feige J, Müller W, Kube S, Hotzel H, Schubert E, Slickers P, Ehricht R. DNA microarray-based genotyping of Chlamydophila psittaci strains from culture and clinical samples. Vet Microbiol. 2009 Mar 16;135(1-2):22-30. Epub 2008 Sep 16.

SAIDENBERG, A. B. S.; KNÖBL, T. Colibacilose em aves silvestres: revisão. Ciência Veterinária nos Trópicos, v. 8, n. 1-3, p. 16-28, 2005.

SAMOUR, J., MCKINNEY, P. Clinical examination. In: SAMOUR J, ed. Avian Medicine. Philadelphia, PA: Mosby; 2000:15-27.

SAMRA, Z., ROSENBERG, S., SOFFER, Y., DAN, M. In vitro susceptibility of recent clinical isolates of Chlamydia trachomatis to macrolides and tetracyclines. Diagn Microbiol Infect Dis. 2001 Mar;39(3):177-9.

SANTOS, J. A. Patologia especial dos animais domésticos (mamíferos e aves). 2 ed. Rio de Janeiro: Guanabara Koogan, 1986.

SBOROV, V. M., SUTHERLAND, D. A. Fatty Liver Following Aureomycin and Terramycin Therapy in Chronic Hepatic Disease. Gastroenterology, v. 18, p. 598, 1951.

SCANLAN, C. M. Introducción a la bacteriología veterinaria. Zaragoza: Editoria Acribia, p. 269-273, 1991.

SCHEPETIUK, S., KOK, T., MARTIN, L., WADDELL, R., HIGGINS, G. Detection of Chlamydia trachomatis in urine samples by nucleic acid tests: comparison with culture and enzyme immunoassay of genital swab specimens. Journal of Clinical Microbiology, v. 35, p. 3355- 3357, 1997. 
SCHMIDT, R.E.; REAVILL, D.R.; PHALEN, D.N. Liver, 4 chapter. In: Pathology of Pet and Aviary Birds. Ames, lowa: Blackwell Publishing Company, p.67-93, 2003.

SCHMIDT, H.; SCHEEF, J.; MORABITO, S.; CAPRIOLI, A.; WIELER, L. H.; $\mathrm{KARCH}, \mathrm{H}$. A New shiga-toxin 2 variant (st2f) from Escherichia coli isolated from pigeons. Applied and Environmental Microbiology, v. 66, n. 3, p. 1205-1208, 2000.

SCHREMMER, C.; LOHR, J. E.; WASTLHUBER, U.; KÖSTERS, J.; RAVELSHOFER, K.; STEINRÜCK, H.; WIELER, L. H. Enteropathogenic Escherichia coli in Psittaciformes. Avian Pathology, v. 28, n. 1, p. 349-354, 1999.

SHEWEN, P.E. Chlamydial infection in animals: a review. Can. Vet. J., v. 21, p. $2-11,1980$.

SILLIS, M., WHITE, P.M. Rapid diagnosis of psittacosis. Lancet. Mar 24;335(8691):726, 1990.

SIMPSON, V. R. Post-mortem examination. In: Manual of psittacine birds. Cheltenham: BSAVA, p. 69-86, 1996.

SMITH, J.E. Iron metabolism and its disorders. In: KANEKO, J.J.; HARVEY, J.W.; BRUSS, M.L. Clinical Biochemistry of Domestic Animals, 5. ed. San Diego: Academic Press, p.223-239, 1997.

SMITH, K.A., Compendium of Measures to Control Chlamydophila psittaci (formerly Chlamydia psittaci) Infection Among Humans (Psitacosis) and Pet Birds,54 2009: Diagnosis and Treatment. Compend. Contin. Educ. Pract. Vet., v.24, n.5, p. 328-335, 2009. Disponivel em: <

http://www.nasphv.org/Documents/Psittacosis.pdf> Acesso em: 15 Nov 2009.

SOMANI, J., BHULLAR, V. B., WORKOWSKI, K. A., FARSHY, C. E., BLACK, C. M.. Multiple drug-resistant Chlamydia trachomatis associated with clinical treatment failure. J. Infect. Dis., v. 181, p. 1421-1427, 2000. 
SPENCER, L. Pets prove therapeutic for people with AIDS. J. Am. Vet. Med. Assoc., v.201, n.11, p. 1665-1668, 1992.

STALKER, M.J., HAYES, M.A.. Liver and biliary system, p.297-388. In: Maxie M.G. (ed.), Jubb, Kennedy, and Palmer's Pathology of Domestic Animals. Vol.2. 5th ed. Saunders Elsevier, Philadelphia. 2007. 771p.

STAMM, W.E. Toward control of sexually transmitted chlamydial infections. Ann Intern Med. Sep 1;119(5):432-4, 1993.

STARY, A. Diagnosis of genital Chlamydia trachomatis infections. Proceedings of the 4th Meeting of the European Society for Chlamydia Research, August 20-23, 2000, Helsinki, Finland, p. 61-64. 2000.

STORZ, J. Overview of animal diseases induced by chlamydial infections. In: BARRON, A.L., Ed. Microbiology of Chlamydia,. CRC Press, Boca Raton, Florida, USA, p. 167-192,1988.

SUCHLAND, R.J., GEISLER, W.M., STAMM, W.E. Methodologies and cell lines used for antimicrobial susceptibility testing of Chlamydia spp. Antimicrob Agents Chemother. Feb; v. 47(2), p. 636-42, 2003.

SUSSMANN, M. Escherichia coli and human disease. In: SUSSMAN, M. Escherichia coli mechanisms of virulence. Cambridge, Reino Unido: University Press, p. 3-48, 1997.

HARKINEZHAD T., VERMINNEN, K., BUYZERE, M., RIETZSCHEL, E., BEKAERT, S., VANROMPAY, D. Prevalence of Chlamydophila psittaci infections in a human population in contact with domestic and companion birds. J. Med. Microbiol., v. 58, p. $1207-1212,2009$.

TAKASHIMA, I., IMAI, Y., ITOH, N., KARIWA, H., HASHIMOTO, N., Polymerase chain reaction for the detection of Chlamydia psittaci in the faeces of budgerigars. Microbiol. Immunol, v. 40, p. 21-26, 1996. 
TELFER, B.L., MOBERLEY, S.A., HORT, K.P., BRANLEY, J.M., DWYER, D.F., MUSCATELLO, D.J. Probable psittacosis outbreak linked to wild birds. Emerg Infect Dis., v. 11, p. 391-7, 2005.

THIELE, D., WITTENBRINK, M.M., FISCHER, D., KRAUSS, H. Evaluation of the polymerase chain reaction (PCR) for detection of Chlamydia psittaci in abortion material from ewes. Int. J. Med. Microbiol. Virol. Parasitol. Infect. Dis., v. 277, p. 446-453, 1992.

THOMSON, R. G. Patologia Geral Veterinária, Rio de Janeiro: Editora Guanabara Koogan S. A. 1983.

TRÁVNICEK, M., CISLÁKOVÁ, L., DEPTUŁA, W., STOSIK, M., BHIDE, M.R. Wild pigeons and pheasants: a source of Chlamydophila psittaci for humans and animals. Ann Agric Environ Med., v. 9(2), p. 253-5, 2002.

TULKENS, P.M. Intracellular distribution and activity of antibiotics. Eur J Clin Microbiol Infect Dis., v. 10(2), p. 100-6. 1991.

TUMOVÁ, E., SKRIVAN, M., MAROUNEK, M., PAVLÁSEK, I., LEDVINKA, Z., Performance an oocyst shedding in broiler chickens orally infected with Cryptosporidium baileyi and Cryptosporidium meleagridis. Avian Dis., v.46, n.1, p.203-207, 2002.

VANROMPAY, D., ANDERSEN, A.A., DUCATELLE, R., HAESEBROUCK, F. Serotyping of European isolates of Chlamydia psittaci from poultry and other birds. J Clin Microbiol., v. 31(1), p.134-7, 1993.

VANROMPAY, D., BUTAYE, P., SAYADA, C., DUCATELLE, R., HAESEBROUCK, F. Characterization of avian Chlamydia psittaci strains using omp1 restriction mapping and serovar-specific monoclonal antibodies. Res Microbiol. , v. 148(4), p. 327-33, 1997.

VANROMPAY, D., DUCATELLE, R. HAESEBROUCK, F. Chlamydia psittaci infections: a review with emphasis on avian chlamydiosis. Vet. Microbiol., v. 45, p. 93-119, 1995. 
VANROMPAY, D., COX, E., VOLCKAERT, G., GODDEERIS, B. Turkeys are protected from infection with Chlamydia psittaci by plasmid DNA vaccination against the major outer membrane protein. Clin. Exp. Immunol. v. 118, p. 49$55,1999$.

VANROMPAY, D., HARKINEZHAD, T., VAN DE WALLE, M., BEECKMAN, D.S., VAN DROOGENBROECK, C., VERMINNEN, K., LETEN, R., MARTEL, A., CAUWERTS, K., Chlamydophila psittaci transmission from pet birds to humans. Emerg. Infect. Dis., v. 13, p. 1108-1110, 2007.

VANROMPAY, D., VAN NEROM, A., DUCATELLE, R., HAESEBROUCK, F., Evaluation of five immunoassays for detection of Chlamydia psittaci in cloacal and conjunctival specimens from turkeys. J. Clin. Microbiol. v. 32, p. 14701474, 1994.

WAINRIGHT, A.P., BEAUMONT, A.C., KOX, W.J. Psittacosis diagnosis and management of severe pneumonia and multi-organ failure. Intens. Care. Med., v. 13 , p. 419-421, 1987.

WILLIAMS. J., TALLIS, G., DALTON, C., BEATON, S., CATTON, M., ELLIOTT, J., CARNIE, J., Community outbreak of psittacosis in a rural Australian town. Lancet, v. 351, p. 1697-1699, 1998.

WORELL, A.B. Toucans and Mynahs. In: ALTMAN, R.B.; CLUBB, S.L.; DORRESTEIN, G.M.; QUESENBERRY, K., Avian Medicine and Surgery. Philadelphia: W.B. Saunders, p. 910-917, 1997.

WORTHEM, R.B.; SANDERS,R.J.; FITZPATRICK, L.J. Avaliação de programas: Concepções e práticas. Ed. Gente 730 p. São Paulo, 2004.

YESNER, R., KUNKEL, P., Preliminary Observations on the Effect of Aureomycin, Terramycin, Tibione, Combined Tibione, and Streptomycin, and Chloromycetin on the Morphology of the Liver in Man. Yale J. Biol. \& Med., v. 23, p. 299, 1951.

YUNG, A.P., GRAYSON, M.L., Psittacosis--a review of 135 cases. Med J Aust. v. 148(5), p. 228-33, 1988. 
ZIPRIN, R.L.; CORRIER, D.E.; DeLOACH, J.R. Control of established Salmonella typhimurium intestinal colonization with in vivo-passaged anaerobes. Avian Dis., v.37, p.183-188, 1993. 


\section{APENDICE A}

Questionário $N \circledast$

Ficha da Clinica $\overline{N \otimes}$

Questionário aplicado à consumidores finais de aves de companhia

Caro cliente, Com o compromisso de melhorar nosso atendimento, buscando qualidade de vida para seu animal e sua família, solicitamos que responda a este questionário.

Este formulário será utilizado como parte de uma Tese de mestrado realizada no Departamento de Epidemiologia Veterinária Aplicada à Zoonoses da Faculdade de Medicina Veterinária e Zootecnia da Universidade de São Paulo (USP). Para tanto garantimos que os dados pessoais não serão divulgados fora deste objetivo.

No caso de duvidas em relação ao conteúdo deste questionário por favor consulte nossa equipe para maiores esclarecimentos.

NOME:

END:

CONTATO: AVE (ESPÉCIE):

1- Sobre o consumo de água de sua ave, você pode afirmar que:

[ ] Quase não observa o consumo de água

[ ] Consome água normalmente

[ ] Consome grande quantidade de água

[ ]Outro, Exemplifique:

2- Sobre a temperatura de sua ave, você pode afirmar que:

[ ] Nunca observou temperatura elevada

[ ] A ave sempre teve uma temperatura mais levada

[ ] Somente em alguns momentos a ave apresenta temperatura mais elevada

[ ]Outro, Exemplifique:

3- A ave apresentou Sinusite ou Conjuntivite?(explicar os termos)

[] Nunca apresentou estes sinais

[] Sim, mas passou com tempo sem a necessidade de tratamento

[] Sim, mas melhorou com tratamento com antibiótico. Qual?.....

[ ]Outro, Exemplifique:

4- Sobre problemas respiratórios, sua ave: 


\begin{abstract}
[] Nunca teve
[] Teve, mas passou com o tempo sem a necessidade de tratamento

[ ] Teve, necessitou de tratamento veterinário para melhorar. Qual?....

[ ]Outro, Exemplifique:
\end{abstract}

5- Sobre problemas intestinais, sua ave:

[] Nunca teve

[] Teve, mas passou com o tempo sem a necessidade de tratamento

[ ] Teve, necessitou de tratamento veterinário para melhorar. Qual?...

[ ]Outro, Exemplifique:

6- Sobre a limpeza da gaiola, você:

[] Limpa diariamente

[ ] Limpa duas vezes ao dia para evitar acumulo de fezes

[ ] Usa areia ou substrato no funda da gaiola para evitar a limpeza diária; Limpa a cada dois dias ou mais

[ ]Outro, Exemplifique:

7- Sobre a limpeza dos poleiros, você:

[ ] Limpa diariamente

[ ] Limpa duas vezes ao dia para evitar acumulo de fezes

[ ] Limpa a cada dois dias ou mais

[ ]Outro, Exemplifique:

8- Sobre a limpeza da gaiola e acessórios, você:

[ ] Utiliza água e sabão

[ ] Utiliza água e sabão e depois aplica desinfetantes. Qual?...

[] Nunca lavou a gaiola e acessórios

[ ]Outro, Exemplifique:

9- Ao limpar a gaiola, você usa alguma proteção?

( ) Não ( ) Sim . Qual?

10- Em relação ao convívio com a ave, você costuma entrar em contato direto, beijá-la e/ou cheirá-la quando brinca:

[] Nunca

[ ] Raramente. Com que freqüência?....

[ ] Sempre. Com que freqüência?....

[ ]Outro, Exemplifique:

11-Zoonoses são doenças naturalmente transmissíveis entre o homem e os animais. Você tinha conhecimento sobre problemas de zoonoses quando adquiriu a ave?

[ ] Não tinha conhecimento 
[] Sim, mas desconhecia quais eram

[] Sim, tinha pleno conhecimento das zoonoses. Quais vc conhece?

[ ]Outro, Exemplifique:

12- Perdeu alguma ave por doença ou morte subita?

[] Não

[] Sim. Mas desconheço o motivo

[] Sim. Qual era a doença/ sintomas? Fale um pouco sobre isto. 


\section{APÊNDICE B}

FICHA DE ACOMPANHAMENTO
COR:
GAIOLA:
ID:

\section{Procedimento / Progresso}

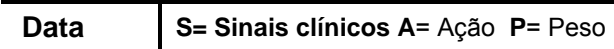

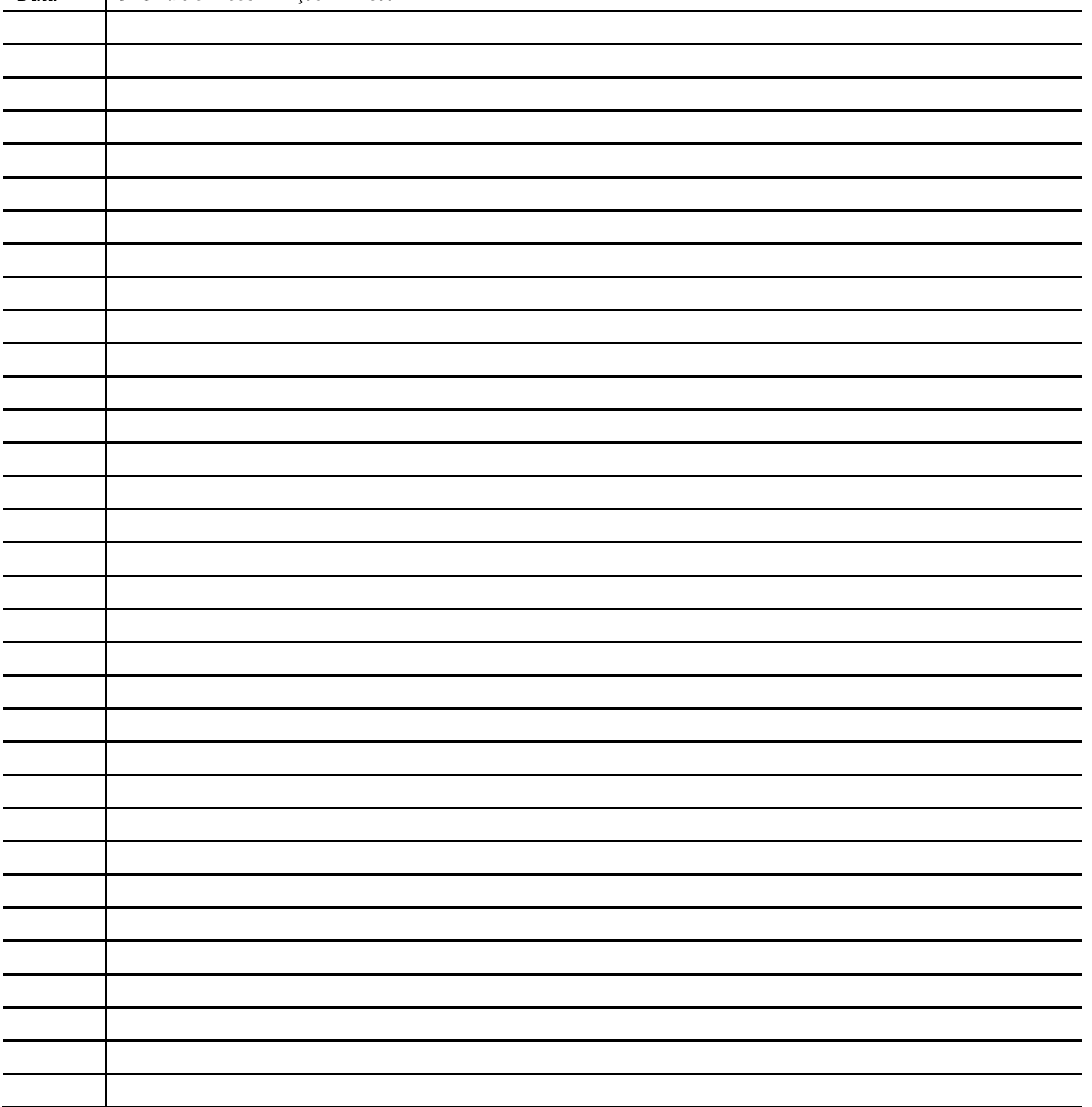




\section{ANEXO A}

\section{MINUTA}

\section{Prezados Senhores:}

Estamos encaminhando, em anexo, Nota Técnica sobre provável surto de Psitacose ocorrendo no Estado do Rio Grande do Sul, para conhecimento.

Sabe-se a importância das doenças classificadas como zoonoses, ou seja, transmitidas dos animais para o homem, sendo várias delas alvo de ações de Saúde Pública. Em relação à psitacose, a partir de 2003 , foram registrados outros dois surtos com acometimento de pessoas que atenderam aves apreendidas de traficantes ou que compraram animais oriundos do tráfico.

Considerando a relevância do evento para a Saúde Pública da população gaúcha, com adoecimento de várias pessoas em locais diferentes do Estado e repercussão na mídia, solicita-se especial atenção de sua instituição, no sentido de:

Divulgar informações para os profissionais sobre a situação atual do problema;

- Desenvolver medidas, de acordo com a especificidade de cada instituição, para minimizar os riscos de transmissão das zoonoses aos profissionais e população em geral;

- Promover a utilização de equipamentos de proteção individual (EPI), conforme a necessidade;

Promover as atividades de vacinação para os profissionais envolvidos, conforme as indicações técnicas.

Oportunamente, será realizado fórum sobre "Zoonoses de importância para a Saúde Pública e riscos para a população humana", para ampla discussão sobre o tema e desenvolvimento de ações conjuntas.

Certos de sua colaboração e colocando-nos à disposição para quaisquer esclarecimentos, despedimo-nos atenciosamente, 


\section{NOTA TÉCNICA SOBRE PROVÁVEL SURTO DE PSITACOSE 21/12/07}

No dia 28/11/07, a Patrulha Ambiental da Brigada Militar (PATRAM) e a Polícia Rodoviária Federal apreenderam um carregamento de 424 caturritas (Myopsitta monachus) em Pântano Grande-RS. Os traficantes de animais, responsáveis pelo transporte tinham, como destino final, a região metropolitana de Porto Alegre.

As aves foram recolhidas na sede do Pelotão da Brigada Militar em Rio Pardo, onde passaram a noite. Durante o dia 29/11, os animais foram observados e alimentados. Na tarde do mesmo dia, as aves foram transportadas para o Hospital Veterinário da UFRGS em Porto Alegre, onde receberam cuidados intensivos por várias pessoas. No dia seguinte, 210 animais foram encaminhados a uma clínica veterinária em Porto Alegre, outros $\mathbf{8 0}$ foram encaminhados ao zoológico municipal de Canoas e 10 a uma clínica veterinária também em Canoas.

A partir do dia 06/12 algumas pessoas passaram a apresentar sintomas compatíveis com Psitacose: febre, cefaléia, sudorese, calafrios e desconforto respiratório.

O Centro Estadual de Vigilância em Saúde da SES-RS foi notificado da ocorrência do problema em 10/12, pela Coordenação Geral de Vigilância em Saúde da Secretaria Municipal de Saúde de Porto Alegre.

Foi iniciada uma investigação ambiental e epidemiológica, com busca ativa de casos na capital e no interior. Até o momento (21/12), XX pessoas manifestaram sintomas, foram encaminhadas para atendimento médico e coleta de material para exame laboratorial. Os pacientes estão sendo tratados com antibiótico e evoluindo para a cura.

Entre os sintomáticos estão pessoas que tiveram contato direto com as aves: policiais da PATRAM e Policia Rodoviária Federal, veterinários e alunos da UFRGS, funcionários do Zoológico de Canoas e demais pessoas que se envolveram diretamente no cuidado dos animais.

Foram coletadas amostras de sangue e swab de caturitas para análises laboratoriais e uma parte dos animais mortos está preservada para que possam ser submetidos a exames. Alguns animais foram sacrificados e os demais passam por tratamento com antibióticos.

Todas as medidas necessárias para a investigação e controle da situação estão sendo desenvolvidas, visando à proteção da saúde da população gaúcha. Os trabalhos conjuntos estão sendo realizados pelas Vigilâncias Ambiental e Epidemiológica do Centro Estadual de Vigilância em Saúde da SES/RS, Vigilâncias Ambiental e Epidemiológica das $9^{a}, 13^{a}$ e $18^{\text {a }}$ Coordenadorias de Saúde da SES/RS, IPB-Lacen/RS e Vigilâncias Epidemiológica e Ambiental das Secretarias Municipais de Saúde envolvidas (Porto Alegre, Canoas e demais municípios). 


\section{PSITACOSE - INFORMAÇÕES TÉCNICAS}

A Psitacose é uma doença infecciosa aguda causada por uma bactéria, a Chlamydophila psittaci. A doença tem ocorrência mundial. Os principais reservatórios da bactéria são as aves, principalmente os psitacídeos (caturritas, papagaios, araras, periquitos), embora possa acometer aves em geral. Estudos apontam que podem ser infectadas em torno de $\mathbf{4 6 5}$ diferentes espécies de aves.

Os sintomas nas aves são variáveis e inespecíficos, como: perda de peso, letargia, diarréia (entre o amarelo e esverdeado), sinusite, coriza, penas arrepiadas e outros. $O$ emagrecimento progressivo conduz à caquexia e óbito, que sobrevêm após um período de aproximadamente uma a duas semanas. São igualmente registrados casos de morte súbita, sem sintomatologia prévia. Entretanto, na maioria dos casos, as aves não apresentam sintomas e podem excretar a bactéria por toda vida.

Quando as aves, principalmente jovens, são expostas a estresse como aprisionamento e transporte (Figura 01), a Chlamydophila psittaci encontra condições ideais para aumentar sua população e tornar-se potencialmente perigosa, uma vez que aumenta também a eliminação da bactéria pelas excretas e secreções das aves.

É importante realçar que aves livres na natureza não representam nenhum risco à saúde da população.

A transmissão para os seres humanos ocorre principalmente por via respiratória, através da aspiração de poeira contaminada por dejetos ou secreções, durante a manipulação de animais doentes ou portadores da bactéria.

O período de incubação é de 07 a 14 dias, podendo chegar a 2 meses. Não há prova da transmissão de pessoa para pessoa, portanto não há necessidade de isolamento dos pacientes. No homem, os sintomas iniciam abruptamente e os principais são: febre, calafrios, dor de cabeça, mal estar e dores musculares. Normalmente surge uma tosse seca quer pode ser acompanhada de dificuldade de respirar. Podem ocorrer complicações respiratórias, caso o paciente não seja tratado. Não existe vacina contra a Psitacose, a principal medida de controle da doença é a utilização de antibióticos.

A população em geral deve evitar contato direto com animais silvestres. É importante lembrar que capturar, vender e comprar espécies da fauna silvestre é crime. Os profissionais que tem contato com animais silvestres (veterinários, biólogos e outros) devem fazer uso de equipamentos de proteção individual quando houver necessidade de manuseá-los. 


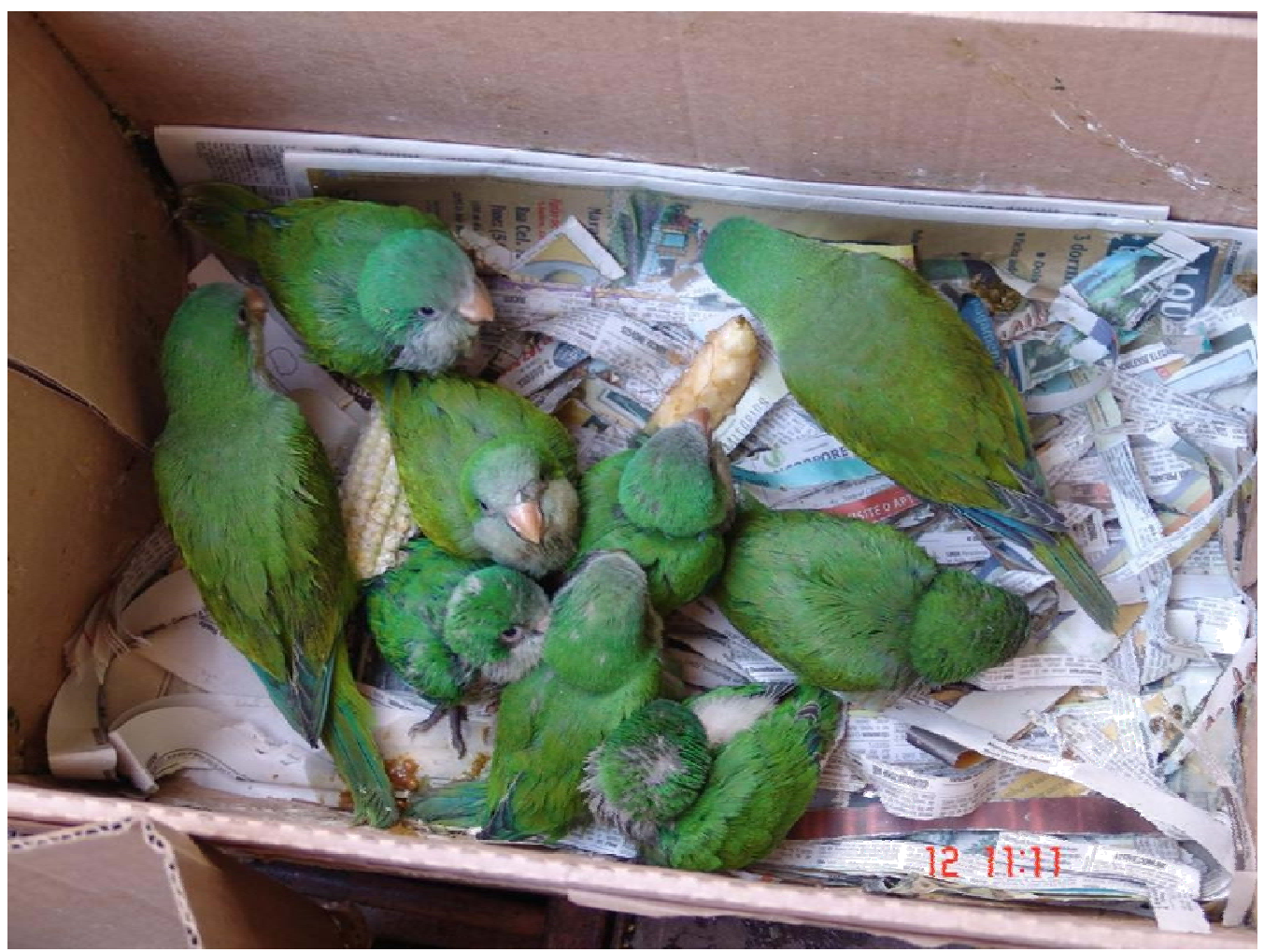

Figura 01 - Caturritas jovens, apreendidas com traficantes. 